Pacific Northwest

National Laboratory

Operated by Battelle for the

U.S. Department of Energy

\title{
Assessment of New Calculation Method for Toxicological Sums-of-Fractions for Hanford Tank Farm Wastes
}

\author{
L. A. Mahoney
}

October 2006

Prepared for the U.S. Department of Energy under Contract DE-AC05-76RL01830 



\title{
DISCLAIMER
}

This report was prepared as an account of work sponsored by an agency of the United States Government. Neither the United States Government nor any agency thereof, nor Battelle Memorial Institute, nor any of their employees, makes any warranty, express or implied, or assumes any legal liability or responsibility for the accuracy, completeness, or usefulness of any information, apparatus, product, or process disclosed, or represents that its use would not infringe privately owned rights. Reference herein to any specific commercial product, process, or service by trade name, trademark, manufacturer, or otherwise does not necessarily constitute or imply its endorsement, recommendation, or favoring by the United States Government or any agency thereof, or Battelle Memorial Institute. The views and opinions of authors expressed herein do not necessarily state or reflect those of the United States Government or any agency thereof.

\author{
PACIFIC NORTHWEST NATIONAL LABORATORY \\ operated by \\ BATTELLE \\ for the \\ UNITED STATES DEPARTMENT OF ENERGY \\ under Contract DE-AC05-76RL01830
}

Printed in the United States of America

Available to DOE and DOE contractors from the

Office of Scientific and Technical Information,

P.O. Box 62, Oak Ridge, TN 37831-0062;

ph: (865) 576-8401

fax: $(865) 576-5728$

email: reports@adonis.osti.gov

\author{
Available to the public from the National Technical Information Service, \\ U.S. Department of Commerce, 5285 Port Royal Rd., Springfield, VA 22161 \\ ph: (800) 553-6847 \\ fax: (703) 605-6900 \\ email: orders@ntis.fedworld.gov \\ online ordering: http://www.ntis.gov/ordering.htm
}

This document was printed on recycled paper.

$(9 / 2003)$ 
PNNL-16067 Rev. 1

\section{Assessment of New Calculation Method for Toxicological Sums-of-Fractions for Hanford Tank Farm Wastes}

L.A. Mahoney

October 2006

Prepared for the U.S. Department of Energy

under Contract DE-AC05-76RL01830

Pacific Northwest National Laboratory

Richland, Washington 99352 



\section{Summary}

The toxicological source terms used for potential accident assessment in the Tank Farms DSA are based on toxicological sums-of-fractions (SOFs) that were calculated in fiscal year 2002 and fiscal year 2003 based on the Best Basis Inventory (BBI) from May 2002, using the method described by Cowley et al. (2003). The present report describes a modified SOF-calculation method that is to be used in future toxicological updates and assessments and compares its results (for the $2002 \mathrm{BBI}$ ) to those of the old method.

In the old method, the Environmental Simulation Program, $\mathrm{ESP}^{1}$, a chemical thermodynamic simulator, was employed on a tank-by-tank basis to determine the identities and the liquid- and dry-solid-phase concentrations of the chemicals in which the BBI analytes would be present at chemical equilibrium. The concentrations used as ESP input were the average composition of the waste in the tank, as calculated from BBI data, in effect assuming that all layers were completely mixed together. The composition predicted by ESP was used as the basis for the toxicological source term.

The new method does not process the BBI data through ESP. It uses the analyte concentrations and phases given in BBI for each layer ${ }^{2}$ in the tank waste and assigns a chemically plausible compound to each analyte, based largely on the prevalent compounds predicted by ESP in the old method for the 2002 BBI. Each analyte is assigned the same compound in all tanks; therefore, the new methodology does not include the whole set of compounds in which an analyte might appear. To the extent that different compounds appear in different tanks and that these compounds have different toxicities, any given analyte may be represented in a more or less toxic fashion than in the old method. To conservatively account for variation in composition within a tank and to match the method used in radiological calculations, the SOFs that are used to represent each tank are the maximum SOFs over all the layers (liquid or wet bulk solids).

This study focuses on the replacement of ESP modeling by the direct use of BBI data. The method comparison therefore considered only the handling of the primary $\mathrm{BBI}$ analytes that were originally modeled using the ESP code (Ag, $\mathrm{Al}, \mathrm{Bi}, \mathrm{Ca}, \mathrm{Cl}, \mathrm{Cr}, \mathrm{F}, \mathrm{Fe}, \mathrm{Hg}, \mathrm{K}, \mathrm{La}, \mathrm{Mn}, \mathrm{Na}, \mathrm{Ni}, \mathrm{NO}_{2}, \mathrm{NO}_{3}$, free $\mathrm{OH}$, $\mathrm{Pb}, \mathrm{PO}_{4}, \mathrm{Si}, \mathrm{SO}_{4}, \mathrm{Sr}, \mathrm{TOC}, \mathrm{U}$, and $\mathrm{Zr}$ ), not the "trace" analytes. The discussion of the contributions of "trace" analytes is deferred to another document (Meacham et al. 2006). The new and old methods were compared on the basis of the same inventory (May 2002 BBI) and the same chemical toxicity data (Rev. 21A of TEEL-1, TEEL-2, and TEEL-3), ensuring that all differences in results were caused by method changes alone.

In 50 to $60 \%$ of the Hanford tanks, the new-method SOFs were within $\pm 20 \%$ of the old method, while 15 to $20 \%$ of the tanks showed a difference of more than $\pm 50 \%$. The SOFs were increased by the new method more often than they were decreased. These statements hold for both the liquid and wet bulk solids SOFs. Twelve tanks had SOFs that decreased (and therefore were possibly nonconservative) by more than $50 \%$; only in one tank were wet bulk solids SOFs decreased by more than $50 \%$. For perspective, an uncertainty of $20 \%$ in analyte concentrations is a reasonable expectation for compositions based on sample measurements, considering the uncertainties in sample concentration and density

\footnotetext{
1 The Environmental Simulation Program (ESP) is a registered trademark of OLI Systems, Inc., Morris Plains, New Jersey.

2 Here "layers" has the same meaning as the word "components" that is used in BBI terminology.
} 
analyses and the variability of concentration within the waste. The overall uncertainty might be considerably greater in tanks that have not been sampled.

A detailed though semi-quantitative study was made to learn the reasons for method-related changes in SOFs at TEEL-3. This TEEL level was chosen because new-method SOFs differed from old-method values somewhat more than at the other TEEL levels. Three aspects of the change in SOF calculation method were the causes of significant changes (those exceeding 30\%) in liquid-phase SOFs for TEEL-3:

- In 16 of the 24 tanks in which significant increases occurred, the primary cause was differences between the ESP-predicted and BBI solubilities of analytes (most often $\mathrm{NO}_{3}, \mathrm{NO}_{2}, \mathrm{OH}$, and $\mathrm{Al}$ ). This was also the primary cause of the major decreases in liquid SOFs, which occurred in 14 tanks.

- In 3 of the tanks in which significant increases occurred, the primary cause was the use of analyte concentrations from the maximum-SOF layer instead of the tank-average waste.

- In 5 of the tanks in which significant increases occurred, the primary cause was the increase in the effective toxicity of TOC that resulted from using oxalate to represent all TOC.

Several aspects of the change in SOF calculation method were the causes of significant changes (those exceeding 30\%) in wet bulk solid SOFs for TEEL-3:

- In 37 of the 45 tanks in which significant increases occurred, the primary cause was the use of the concentrations of the layer that had the maximum SOF in the tank instead of the tank-average waste.

- In all 5 of the tanks in which significant decreases occurred and in one of the tanks that showed an increase, the primary cause was solubility changes (ESP versus BBI).

- In 4 of the tanks in which significant increases occurred, the primary cause was an increase in the effective toxicity of lead because of its assignment to the compound lead hydroxide.

- In 2 of the tanks in which significant increases occurred, the primary cause was an increase in the effective toxicity of TOC because of its assignment to oxalate.

- In one of the tanks in which significant increases occurred, the primary cause was adjustments made to the ESP compositions in the old method.

Taking the results for liquid and wet bulk solids SOFs together, it is clear that the use of the maximumlayer approach was the dominant reason why the new method calculated different (in particular, larger) SOFs than the old. This maximum-layer approach was chosen to be consistent with the approach used in calculating ULDs for radiological assessments, and led to a change in the direction of conservatism. Differences between ESP and BBI solubilities were the next most common reason for differences between new and old SOFs, particularly in the liquid phase. The solubility-related changes in SOF were roughly equally distributed between increases and decreases. No general statement can be made about whether ESP modeling (as in the old method) or direct use of BBI data provides more accurate results; there were examples of both. Changes in the effective toxicities of TOC and lead were the third most common reason. These toxicity changes increased SOFs and so were in a conservative direction. Although decreases in Ca and Al toxicity decreased the new method SOFs for a few tanks, in no case did they cause the new-method SOFs to be significantly lower than those generated by the old method. 


\section{Contents}

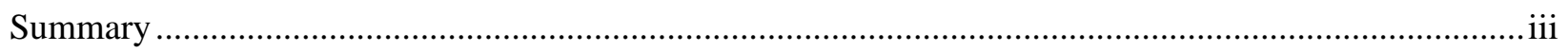

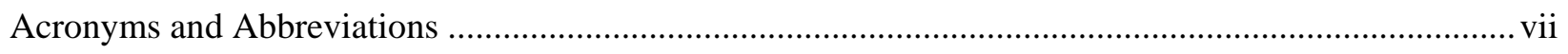

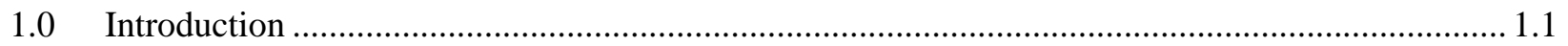

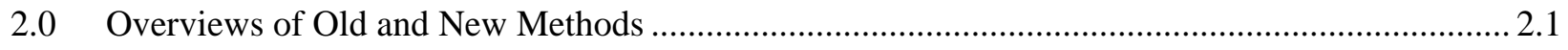

2.1 Overview of Old Method ............................................................................................. 2.1

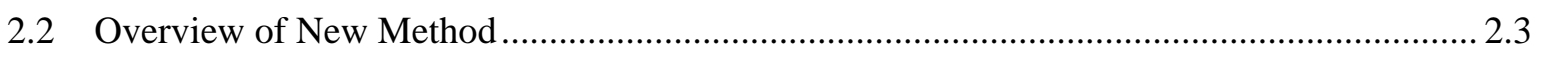

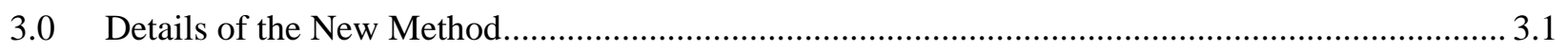

3.1 Change in Assignment of Compounds to Analytes............................................................. 3.1

3.2 Change in the Basis of the Solid Phase …........................................................................... 3.3

3.3 Changes in Phase Concentrations of Analytes ................................................................... 3.4

3.3.1 Use of Layer Concentrations and Maximum-Layer SOFs ....................................... 3.4

3.3.2 Using Analyte Phase Concentrations Taken Directly From the BBI ......................... 3.4

3.3.3 Basing the $\mathrm{Cr}(\mathrm{VI}) / \mathrm{Cr}(\mathrm{III})$ Split on the BBI Wash Factor for Chromium .................... 3.5

3.3.4 Use of the ESP-Modeled Hydroxide Concentrations as Defaults .............................. 3.6

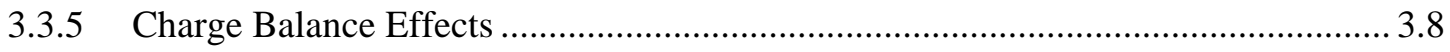

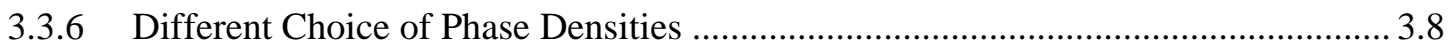

4.0 Comparison of Results for New and Old Methods.................................................................. 4.1

4.1 Basis for Method Comparison......................................................................................... 4.1

4.2 Overall Comparison of Major-Analyte SOFs Calculated by Old and New Methods ............ 4.2

4.3 Detailed Evaluation of Changes in Major-Analyte Liquid-Phase SOFs ............................... 4.7

4.3.1 Effect on Liquid-Phase SOFs of Using Default Hydroxide Concentrations ........... 4.10

4.4 Detailed Evaluation of Changes in Major-Analyte Wet Bulk Solids SOFs ......................... 4.10

4.4.1 Effect on Wet-Bulk-Solid-Phase SOFs of Using Default Hydroxide

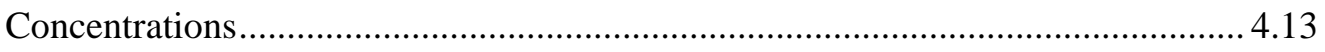

4.4.2 Effect of Compound Assignments on Wet-Bulk-Solid-Phase SOFs....................... 4.13

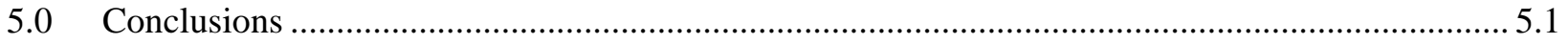

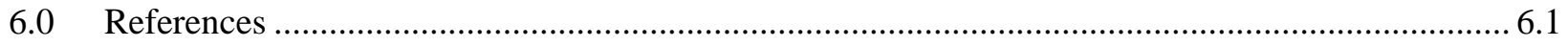

Appendix A - User-Specified Chemical Equations Used by New Method in Comparison of New and Old Methods

Appendix B - Basis for Assignment of Major Compounds in the New SOF Calculation Method...........B.1

Appendix C - Default Free Hydroxide Concentration Inputs .....................................................................

Appendix D - Estimated Dry-Solid Volume Fraction in Wet Bulk Solids ............................................ D.1 


\section{Figures}

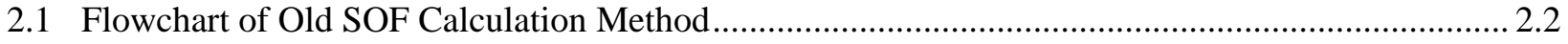

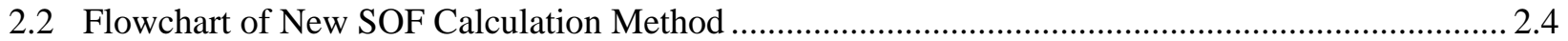

4.1 Comparison of Old and New Liquid-Phase SOFs for TEEL-1, -2, and -3 ...................................... 4.3

4.2 Comparison of Old and New Wet Bulk Solids SOFs for TEEL-1, -2 , and -3 .................................. 4.6

4.3 Comparison of Old and New Wet Bulk Solids SOFs for TEEL-2 and -3 ..................................... 4.7

\section{Tables}

4.1 Differences Between Old and New Liquid-Phase SOFs for TEEL-1, -2, and -3

4.2 Differences Between Old and New Wet Bulk Solids SOFs for TEEL-1, -2, and -3

4.3 Causes of Method-Related Liquid-Phase SOF-3 Decreases of More Than 30\%

4.4 Causes of Method-Related Liquid-Phase SOF-3 Increases of More Than 30\%

4.5 Causes of Method-Related Wet Bulk Solids SOF-3 Decreases of More Than 30\%

4.6 Causes of Method-Related Wet Bulk Solids SOF-3 Increases of More Than 30\% 


\section{Acronyms and Abbreviations}

$\begin{array}{ll}\text { BBI } & \text { Best Basis Inventory } \\ \text { BBI-S } & \text { Best Basis Inventory - Supplemental } \\ \text { DST } & \text { Double-shell tank } \\ \text { EDTA } & \text { Ethylenediaminetetraacetate } \\ \text { HEDTA } & \text { Hydroxyethylethylenediaminetriacetate } \\ \text { SOF } & \text { Sum of fractions } \\ \text { SST } & \text { Single-shell tank } \\ \text { TCD } & \text { Tank Characterization Database } \\ \text { TEEL } & \text { Temporary Emergency Exposure Limit } \\ \text { TIC } & \text { Total inorganic carbon } \\ \text { TOC } & \text { Total organic carbon } \\ \text { ULD } & \text { Unit liter dose }\end{array}$





\subsection{Introduction}

The toxicological source terms used for potential accident assessment in the Tank Farms DSA is based on toxicological sums-of-fractions (SOFs) that were calculated in FY02 and FY03 based on the Best Basis Inventory (BBI) from May 2002, using the method described by Cowley et al. (2003). The present report describes a modified SOF-calculation method that is to be used in future toxicological updates and assessments, gives its basis, and compares its results (for the $2002 \mathrm{BBI}$ ) to those calculated by the old method.

In the old method, the Environmental Simulation Program, $\mathrm{ESP}^{1}$, a chemical thermodynamic simulator, was employed on a tank-by-tank basis to determine the identities and the liquid- and dry-solid-phase concentrations of the chemicals in which the BBI analytes would be present at chemical equilibrium. The concentrations used as ESP input were the average composition of the waste in the tank, as calculated from BBI data, in effect assuming that all layers were completely mixed together. ESP predicted concentrations of chemicals in the solid and liquid phases, and drew no distinction between supernatant and interstitial liquids. SOFs derived from ESP solids were consequently for dry solid, not wet bulk solids (which incorporate interstitial liquid). The liquid and dry-solid concentrations of ESP-predicted compounds then were input to the "SOF Program," which converted ions into compounds as necessary and paired the chemical composition data with toxicological parameters to obtain the toxicological source terms. The toxicological parameter chosen in RPP-8369 is the Temporary Emergency Exposure Limit (TEEL), developed and periodically updated by DOE Subcommittee on Consequence Assessment and Protective Actions (SCAPA). ${ }^{2}$ There are four TEEL levels, TEEL-0, -1, -2 and -3, defined as the airborne concentrations of a chemical that could be expected to have certain human health consequences. The SOF is simply the sum over all chemicals of the dimensionless ratio of concentration divided by the appropriate TEEL. Revision 19 of the TEELs was used by Cowley et al. (2003).

The new method does not process the BBI data through ESP. It uses the analyte concentrations and phases given in BBI for each layer ${ }^{3}$ in the tank waste and assigns chemically plausible compounds to each analyte, based largely on the most prevalent compounds predicted by ESP in the old method for the 2002 BBI. The compound assignments are the same for all tanks. The new methodology includes, not the whole set of compounds in which an analyte might appear, but only the commonest compounds or those that are toxicologically representative of a group of compounds that contain a common analyte. In the new method the basis for the solid phase has been changed to wet bulk solids, a basis that is consistent with BBI usage and with the radiological source term used in the DSA. The SOFs that are used to represent each tank are the maximum SOFs over all the layers (of the appropriate phase) that are present.

1 The Environmental Simulation Program (ESP) is a registered trademark of OLI Systems, Inc., Morris Plains, New Jersey.

2 TEELs set the maximum allowable airborne concentrations of compounds (DOE 2006). TEEL-0 is the concentration at or below which it is believed that nearly all individuals could be exposed without experiencing other than mild transient adverse health effects or perceiving a clearly defined, objectionable odor. At the other end, TEEL-3 is the concentration below which it is believed that nearly all individuals could be exposed without experiencing or developing irreversible or other serious health effects or symptoms which could impair an individual's ability to take protective action. The TEEL level that is appropriate in evaluating accident consequences is selected based on the probability of the accident. There is some ambiguity regarding the name of the current version of TEELs. They were obtained from a website that calls them "Revision 21 " but the spreadsheet of TEELs is called "TEELs_Rev21A_publ.xls”. In this report this set of TEELs is referred to as Rev. 21A.

3 Here "layers" has the same meaning as the word "components" that is used in BBI terminology. 
The object of this report is to provide a detailed description of the new method that is to be used for the 2006 BBI, compare the SOF predictions to those made by the old method, and explain the reasons for the differences. The report focuses on the replacement of ESP modeling by phase data available in the BBI and a simplified, reasonably universal set of chemical equations. This report is limited to those chemicals, primarily the 25 BBI constituents, which were previously addressed by ESP in the old method. Trace constituents, defined here to be any chemical not considered a primary waste constituent in the BBI, are not addressed here. Two exceptions to this are silver and hydroxide; the former because its solid/liquid distribution was determined by ESP in the old method (though it is not a primary BBI constituent), and the latter because it is an extremely important factor in the waste chemistry and its toxicity.

Section 2 of this report describes the old and new methods in more detail. The important differences between the methods are detailed in Section 3. In Section 4, the results given by the two methods are compared. Section 5 contains the conclusions and Section 6 the references. The chemical equations used by the new method are in Appendix A, together with an explanation of them. Appendix B provides the rationale for the choice of compounds to be assigned to each analyte in the new method. Appendixes $\mathrm{C}$ and $\mathrm{D}$ contain tabulations of $\mathrm{OH}^{-}$and $\mathrm{NO}_{2}{ }^{-}$concentrations and of solid volume fractions in wet bulk solids. 


\subsection{Overviews of Old and New Methods}

\subsection{Overview of Old Method}

The study done by Cowley et al. (2003) used the tank-average Best Basis Inventory (BBI) concentrations of major analytes, with ESP modeling of the most significant analytes, to produce SOFs for the liquid and dry solid phases. Figure 2.1 is a flowchart of the old method.

The concentration inputs used by the old method were the following:

- The calculation details files of the May 2002 BBI provided the tank-average concentrations of the major analytes in each tank's waste (TWINS 2002). These included the non-radioactive species in the BBI (Al, Bi, Ca, Cl, Cr, F, Fe, Hg, K, La, Mn, Na, Ni, $\mathrm{NO}_{2}, \mathrm{NO}_{3}, \mathrm{~Pb}, \mathrm{PO}_{4}, \mathrm{Si}, \mathrm{SO}_{4}, \mathrm{Sr}, \mathrm{U}$, and $\mathrm{Zr}$ ) as well as Ag and Cs (the latter being based on Cs-137). Hydroxide was not taken from any BBI data; rather, it was calculated by the ESP model as part of the charge and mass balance.

- Trace analytes (including a number of other inorganic species, organic anions, and organic compounds) were obtained from one of three sources, in decreasing order of preference:

- The calculation details files of the supplemental May 2002 BBI (BBI-S);

- tank characterization database (TCD) consolidated sample analysis results available from TWINS in May 2002; and

- default concentrations that were established for the three tank classes (DSTs, 100-series SSTs, and 200-series SSTs) by taking the maximum concentrations found in BBI-S or TCD for any member of the tank class.

Spreadsheets were used to set up the inputs to the ESP chemical thermodynamic simulator. In these spreadsheets, the soluble concentration of $\mathrm{Cr}$ was used to calculate the split of $\mathrm{Cr}$ between the more toxic and more soluble $\mathrm{Cr}(\mathrm{VI})$ and the less toxic and less soluble Cr(III). The soluble concentration of TOC was used to calculate the split of TOC between soluble acetate and much less soluble oxalate.

The BBI-based tank-average concentrations of major analytes (in $\mu \mathrm{g} / \mathrm{g}$ ) and the BBI-derived splits for $\mathrm{Cr}$ and TOC supplied the input to the ESP model, which predicted the phase concentrations of the numerous compounds and ions that would be formed by the analytes at chemical equilibrium. (Note that oxidation states were frozen; i.e., redox equilibrium was not modeled.) The phases for which ESP provided output were the dry solid (containing no interstitial liquid) and the liquid. ESP also calculated the $\mathrm{OH}$ ion concentration in the liquid and the amounts and densities of each phase that were chemically consistent with the average waste composition. In some cases, where the predicted $\mathrm{OH} / \mathrm{pH}$ differed substantially from the expected or measured value, the charge balance in the ESP inputs was adjusted iteratively, by spreadsheet calculations, to make the model predictions match the measurements more closely. Trace analytes were not modeled by ESP.

When ESP modeling was complete, the Visual Basic software "SOF Program" (version 1.2) converted the ESP-predicted compounds and ions to the most chemically similar compounds for which toxicological parameters were available. This conversion used a large set of stoichiometric chemical equations that maintained the species mass balances. (These equations can be found in Tables C.3 and C.4 of Cowley et al. [2003]) Because ESP tended to underpredict the solubility of $\mathrm{NO}_{2}$ (putting some of it into the solid 


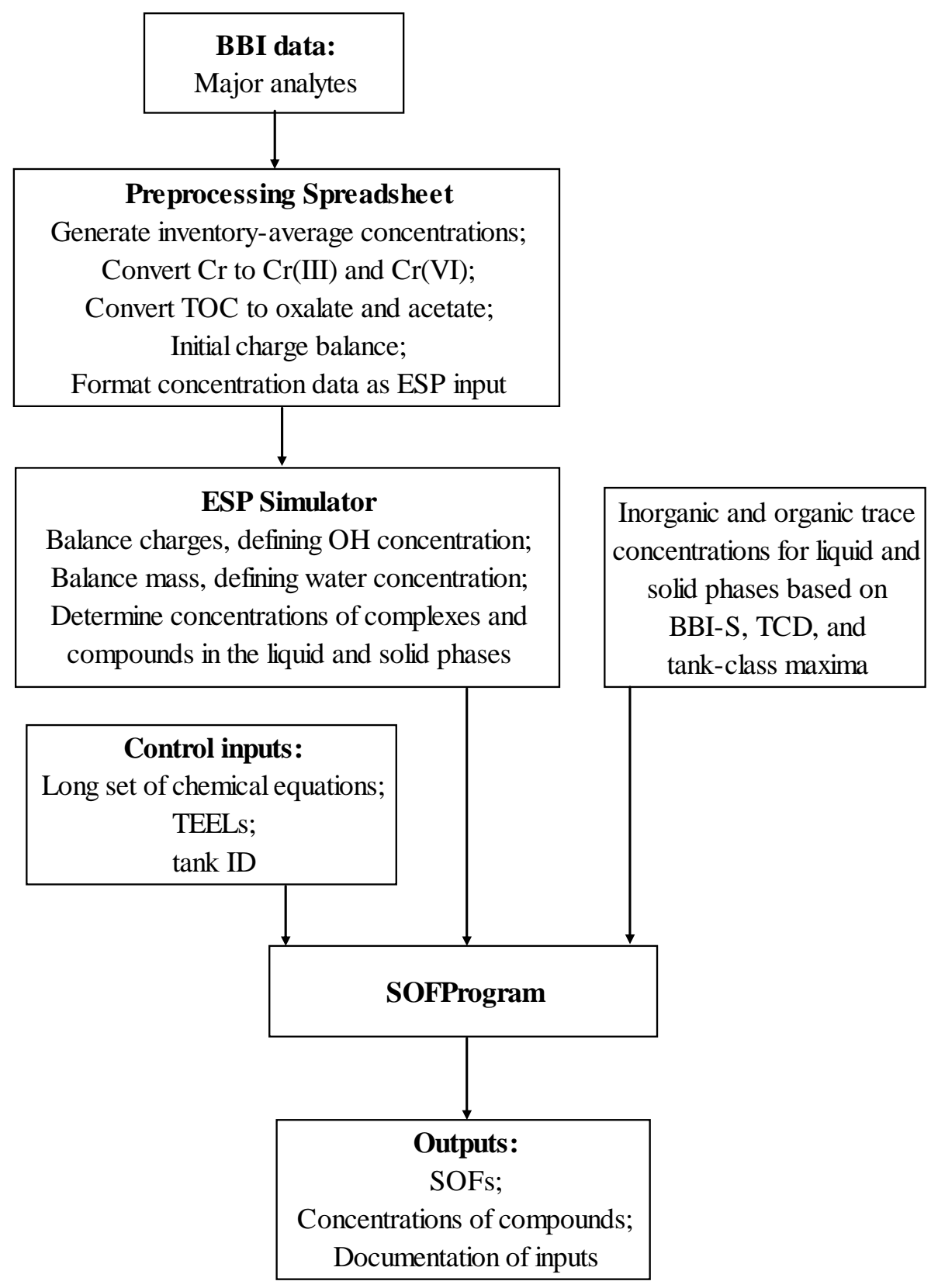

Figure 2.1. Flowchart of Old SOF Calculation Method

phase) and overpredict the solubility of $\mathrm{Hg}$ (putting too much into the liquid phase), the SOF Program chemical equation inputs were also used to put all $\mathrm{NO}_{2}$ in the liquid phase and all $\mathrm{Hg}$ in the solid phase. SOF Program also drew upon spreadsheet-based inputs of the trace analyte concentrations and converted these into appropriate compounds, based on chemical equations in the SOF Program inputs.

Finally, SOF Program used all the converted compound concentrations to calculate the SOFs in each phase for each tank and produced a summary table of the SOFs for the average dry-solid and aqueous liquid phases in all tanks. 
For completeness, it should be noted that Cowley et al. also calculated SOFs for separated organic liquid layers in tanks 241-C-103, C-106, and AY-102 based on information from several sources. Headspace vapor SOFs were determined as well, based on data from the TCD. These did not involve ESP (nor was the SOF Program used to calculate these SOFs) and they are not considered further in this report.

\subsection{Overview of New Method}

The new method starts from the Best Basis Inventory (BBI) concentrations of major analytes in each layer, assigns each analyte to the compound considered most likely to contain it (taking chemical plausibility and toxicological conservatism into account), calculates SOFs for all the layers in the tank, and then selects the maximum layer SOFs to represent the liquid and wet bulk solid phases. Figure 2.2 is a flowchart of the new method.

The concentration inputs used by the new method are the following:

- The calculation details files of the current BBI and BBI-S provide the concentrations of analytes in each layer of the tank waste. (Note the original method used tank-average concentrations.)

- When free $\mathrm{OH}$ and certain trace metal concentration data are not available in the BBI-S, the following substitute data sources are used as defaults:

- In liquid layers, the concentration of free $\mathrm{OH}$ is taken from the ESP output for each tank;

- in wet bulk solids layers, the concentration of free $\mathrm{OH}$ is calculated by scaling the ESP-output liquid-phase concentration of free $\mathrm{OH}$ by a ratio of the BBI-derived inventory-maximum $\mathrm{NO}_{2}$ concentration for the wet bulk solids phase to the ESP-output $\mathrm{NO}_{2}$ concentration for the liquid phase;

- $\quad$ for the fourteen trace metals Ag, As, Be, Cd, Co, Pd, Rh, Se, Sn, Te, Th, Tl, W, and Zn, default concentrations are specified for liquid, saltcake, and sludge types of layers based on BBI protocols.

An Excel spreadsheet was used to acquire the BBI data, make units conversions, and calculate a $\mathrm{Cr}(\mathrm{VI}) / \mathrm{Cr}(\mathrm{III})$ split. All $\mathrm{Cr}$ in the liquid layers was considered to be $\mathrm{Cr}(\mathrm{VI})$. In the wet bulk solid layers, the water wash factor from the BBI database was used to calculate the $\mathrm{Cr}(\mathrm{VI}) / \mathrm{Cr}(\mathrm{III})$ split. The wash factor times the $\mathrm{Cr}$ gave the $\mathrm{Cr}(\mathrm{VI})$ concentration, with the remainder being assigned to $\mathrm{Cr}(\mathrm{III})$. TOC was treated as being $100 \%$ oxalate. The same spreadsheet also drew on the default concentration data for free $\mathrm{OH}$ and the fourteen trace metals as needed.

The concentrations became the input to another Excel spreadsheet that converted all the input analytes to the most plausible compounds for which toxicological data were available. This conversion used a set of stoichiometric chemical equations that maintained the species mass balances; there were fewer equations than in the old method because each analyte was assigned to a smaller number of compounds (in many cases, only to one).

Finally, the spreadsheet used all the converted compound concentrations to calculate the SOFs in each layer for each tank. The output from all runs was gathered to create the summary all-layer table. Finally the maximum layer SOF was selected to represent each phase in the tank. The layer that supplied the maximum SOF could differ for different TEEL levels. 


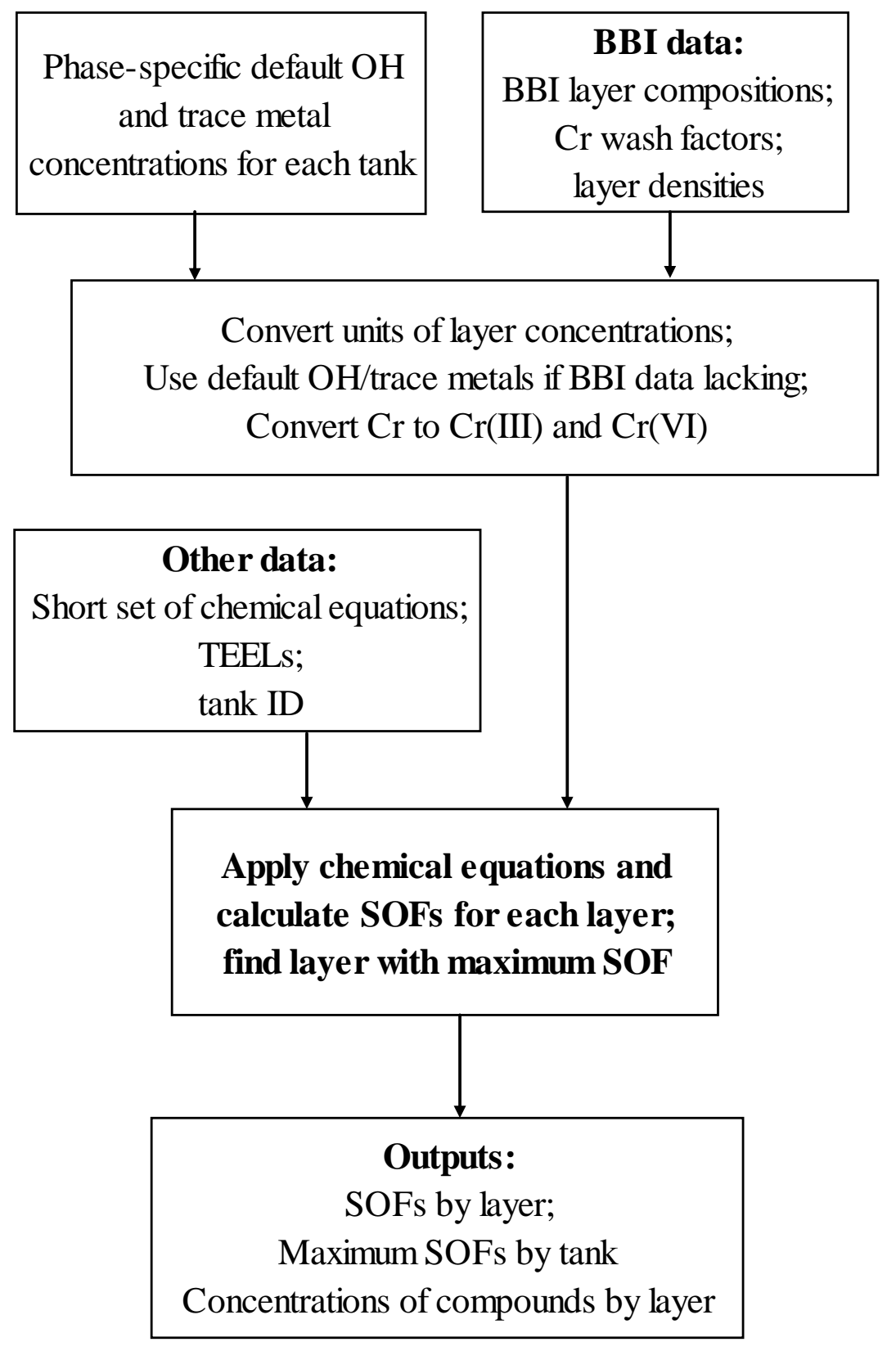

Figure 2.2. Flowchart of New SOF Calculation Method 


\subsection{Details of the New Method}

For the purpose of this comparison, the important changes from the old method to the new method fall into three broad categories:

1. assignment of compounds to analytes on a generic basis, making the SOF calculations less tank-specific but avoiding the resource-intensive use of the ESP model;

2. using a wet-bulk-solids phase instead of a dry-solid phase, thereby putting the toxicological source term on the same phase basis as the radiological source term; and

3. changes in the phase concentrations of analytes, which arise from

- choosing layer concentrations instead of tank-average concentrations;

- deriving the phase distributions of analytes directly from BBI data instead of thermodynamically calculating them with ESP;

- $\quad$ using the chromium wash factor to calculate $\mathrm{Cr}(\mathrm{VI}) / \mathrm{Cr}(\mathrm{III})$ splits;

- obtaining the $\mathrm{OH}$ concentration from the ESP outputs used by Cowley et al. (2003), in cases where no data are available from the BBI;

- charge balance effects on the concentrations of certain significant sodium compounds;

- $\quad$ and using different phase densities to convert mass-basis concentrations to volumetric concentrations, and vice versa.

The three categories of changes are discussed in the remainder of this section.

\subsection{Change in Assignment of Compounds to Analytes}

In the old calculations, the ESP model used equilibrium thermodynamic principles to calculate, on a tankby-tank basis, which compounds or complexes were formed from the major analytes. For example, ESP could potentially predict that $\mathrm{Pb}$ would be present as $\mathrm{Pb}\left(\mathrm{NO}_{2}\right)_{2}, \mathrm{~Pb}\left(\mathrm{NO}_{2}\right)_{3}{ }^{-1}, \mathrm{PbNO}_{2}{ }^{+1}, \mathrm{~Pb}^{+2}$, $\mathrm{Pb}\left(\mathrm{CH}_{3} \mathrm{CO}_{2}\right)_{3}^{-1}, \mathrm{~Pb}(\mathrm{OH})_{2}, \mathrm{HPbO}_{2}^{-1}, \mathrm{PbOH}^{+1}, \mathrm{~Pb}_{3}\left(\mathrm{PO}_{4}\right)_{2}, \mathrm{PbC}_{2} \mathrm{O}_{4}$, and/or $\mathrm{PbO}$ in the liquid phase, and as $\mathrm{Pb}(\mathrm{OH})_{2}, \mathrm{~Pb}_{3}\left(\mathrm{PO}_{4}\right)_{2}$, and/or $\mathrm{PbCO}_{3}$ in the dry-solid phase. ESP estimated concentrations for each of these $\mathrm{Pb}$ compounds and complexes based on the $\mathrm{pH}$ and the counter-ion concentrations that were present in each individual tank.

Taking the concentrations of this mixture of Pb-containing chemicals as inputs, the old-method SOF Program applied user-specified mass-balanced chemical equations (as indicated in Figure 2.1) to convert all the chemicals that ESP predicted into chemically-related neutral compounds for which TEELs were available. This permitted the SOF contributions to be calculated. In the case of $\mathrm{Pb}$, the following equations were applied:

Liquid Phase

$$
\begin{aligned}
& {\left[\mathbf{P b}\left(\mathrm{NO}_{2}\right)_{2}\right]=\left[\mathrm{Pb}\left(\mathrm{NO}_{2}\right)_{2}\right]+\left[\mathrm{Pb}\left(\mathrm{NO}_{2}\right)_{3}{ }^{-1}\right]+\left[\mathrm{PbNO}_{2}{ }^{+1}\right]+\mathrm{NO}_{2} \text { Ratio }^{*}\left(\left[\mathrm{~Pb}^{+2}\right]+\left[\mathrm{Pb}\left(\mathrm{CH}_{3} \mathrm{CO}_{2}\right)_{3}{ }^{-1}\right]\right)} \\
& {\left[\mathbf{P b}\left(\mathrm{NO}_{3}\right)_{2}\right]=\mathrm{NO}_{3} \text { Ratio } *\left(\left[\mathrm{~Pb}^{+2}\right]+\left[\mathrm{Pb}\left(\mathrm{CH}_{3} \mathrm{CO}_{2}\right)_{3}{ }^{-1}\right]\right)}
\end{aligned}
$$


$\left[\mathbf{P b}(\mathbf{O H})_{2}\right]=\left[\mathrm{Pb}(\mathrm{OH})_{2}\right]+\left[\mathrm{HPbO}_{2}^{-1}\right]+\left[\mathrm{PbOH}^{+1}\right]+\mathrm{OHRatio}^{*}\left(\left[\mathrm{~Pb}^{+2}\right]+\left[\mathrm{Pb}\left(\mathrm{CH}_{3} \mathrm{CO}_{2}\right)_{3}^{-1}\right]\right)$

$\left[\mathrm{Pb}_{3}\left(\mathbf{P O}_{4}\right)_{2}\right]=\left[\mathrm{Pb}_{3}\left(\mathrm{PO}_{4}\right)_{2}\right]$

$\left[\mathrm{PbC}_{2} \mathbf{O}_{4}\right]=\left[\mathrm{PbC}_{2} \mathrm{O}_{4}\right]$

$[\mathbf{P b O}]=[\mathrm{PbO}]$

Dry-Solid Phase

$\left[\mathbf{P b}(\mathbf{O H})_{2}\right]=\left[\mathrm{Pb}(\mathrm{OH})_{2}\right]$

$\left[\mathbf{P b}_{3}\left(\mathbf{P O}_{4}\right)_{2}\right]=\left[\mathrm{Pb}_{3}\left(\mathrm{PO}_{4}\right)_{2}\right]$

$\left[\mathrm{PbCO}_{3}\right]=\left[\mathrm{PbCO}_{3}\right]$

These equations represent the concentrations as molarities. The bold-face concentrations on the left of the equal signs are the output of the SOF Program conversion, in other words the values used for SOF calculation. The ones on the right are the ESP output concentrations, the inputs to SOF Program. The variables OHRatio, $\mathrm{NO}_{2}$ Ratio, and $\mathrm{NO}_{3}$ Ratio are used to split the $\mathrm{Pb}$ in some of the ESP species between $\mathrm{OH}^{-}, \mathrm{NO}_{2}{ }^{-}$, and $\mathrm{NO}_{3}{ }^{-}$, in proportion to the concentrations of these major anions.

The chemical equations used in the old SOF calculations can be seen in Tables C.3 and C.4 of Cowley et al. (2003). Appendix $C$ of that document should be referred to for a more complete understanding of the equations and their basis.

In the new method a smaller set of chemical formulas are used for each analyte, and the analyte concentrations from the BBI are used directly as input to the formulas without any intermediary thermodynamic equilibrium calculations. The result is that there is much less tank-to-tank variation between the compounds in which any given analyte is found. However, some variation does arise from the differences in $\mathrm{OH}^{-}, \mathrm{NO}_{2}^{-}$, and $\mathrm{NO}_{3}{ }^{-}$concentrations, which change the associated ratios and therefore change the splits of those analytes to which the ratios are applied. The overall toxicity of an analyte, which depends on which compounds it is found in, tends to be more constant from tank to tank in the new method than in the old.

Continuing the example, the analyte $\mathrm{Pb}$ has the following equations applied to it in the new method:

Liquid Phase

$\left[\mathrm{NaHPbO}_{2}\right]=$ NaRatio* $[\mathrm{Pb}]$

$\left[\mathrm{KHPbO}_{2}\right]=\mathrm{KRatio}^{*}[\mathrm{~Pb}]$

$\underline{\text { Wet bulk solid Phase }}$

$\left[\mathbf{P b}(\mathbf{O H})_{2}\right]=[\mathrm{Pb}]$

In the liquid phase, the variables KRatio and NaRatio are used to split the $\mathrm{HPbO}_{2}{ }^{-}$anion between $\mathrm{K}$ and $\mathrm{Na}$, in proportion to the concentrations of these major cations. Note that as a result of the change several 
$\mathrm{Pb}$ compounds that were considered by Cowley et al. (2003) are no longer considered: $\mathrm{Pb}_{3}\left(\mathrm{PO}_{4}\right)_{2}$, $\mathrm{PbC}_{2} \mathrm{O}_{4}, \mathrm{PbO}$, and $\mathrm{PbCO}_{3}$. This decrease in the number of applicable compounds is typical of many of the analytes. The complete set of chemical formulas used in the new method's SOF calculations can be seen in Appendix A.

The net effect of the change in assignment of compounds is to make the overall toxicity of any given analyte (as averaged over all compounds that are present) somewhat different from its old value. The rationale for the new method's choice of compounds is given in Appendix B. Generally speaking, chemical plausibility, prevalence in the Hanford wastes, and reasonable toxicological conservatism were all considered in choosing the simplified set of compounds. On occasion there were trade-offs between these factors, so some engineering judgment was required to make the choices of compounds.

\subsection{Change in the Basis of the Solid Phase}

Because ESP made predictions of chemical concentrations in terms of liquid and dry solid phases, the solid-phase SOFs calculated by the old method were based only on precipitated compounds for the major species. The solid-phase concentrations of the trace analytes, however, were based directly on BBI or TCD data and therefore were on the basis of wet bulk solids. In the new method all analyte concentrations are taken directly from BBI or TCD data and are therefore on a wet bulk solids basis. As a result, the solid phase now includes chemicals that are part of the interstitial liquid in the bulk solids. This causes two kinds of changes in the SOFs.

To the extent that the interstitial liquid in the wet bulk solids contains lower concentrations of toxic analytes than does the dry solid, the SOFs for wet bulk solids (new method) will be lower than for the dry solid phase (old method) that is part of the bulk. Because the SOFs are measures of toxicity per unit volume of solid, the added volume of water in wet bulk solids dilutes the toxicity and decreases the SOF relative to the dry solid phase. This could produce a factor of 5 to 10 reduction in solid-phase SOF in some wastes (e.g., sludges, which have dilute interstitial liquid and low volume fractions of solids).

However, dilution by water is not the only effect of using a wet bulk solids basis. The interstitial liquid in the wet bulk solids contains toxic analytes whose effect is included in the new-method SOFs. These species $\left(\mathrm{NO}_{2}\right.$, free $\mathrm{OH}$, and $\mathrm{Cr}(\mathrm{VI})$ as particular examples) were not present in as great a volumetric concentration in the dry-solid SOFs calculated by the old method. To the extent the interstitial liquid contains species that are more toxic than those found in the dry solid-which is likeliest to be true for saltcake liquids, which have high $\mathrm{NO}_{2}$, free $\mathrm{OH}$, and $\mathrm{NO}_{3}$ - the solid $\mathrm{SOF}$ in the new method can be higher than in the old method.

Because the effects of dilution and soluble toxic chemicals act in opposite directions, the solid-phase SOFs calculated by the new method may be less or greater than those from the old method. It depends on the concentrations and TEELs of the chemicals that are present.

The basis of the solid-phase SOFs was changed because the radionuclide source term calculations are based on wet bulk solids and it is preferable to put the toxic source term on the same basis. From the point of view of accident analysis, making a toxicological distinction between the liquid and the dry solid that are contained in bulk solids requires one of two assumptions: (1) an accident could physically separate the solid from the interstitial liquid, or (2) the liquid and solid volume fractions in the bulk solids must be assumed. Physical separation of the two phases is unlikely, since the liquid in the bulk solid 
phase (as defined by the BBI) is not drainable. With respect to the second assumption, the volume fractions of solid and liquid are frequently not known. The bulk-wet-solid basis for the solid-phase SOFs is therefore a reasonable and useful representation of the solid part of the accident source term.

In addition, unless the ESP model is used (a resource-intensive effort) there is no consistent method for distributing species between liquid and dry solid phases. The BBI and TCD data might support such calculations for some well-characterized tanks but not for all.

\subsection{Changes in Phase Concentrations of Analytes}

Several different features of the new method caused changes in the phase concentrations of the analytes, compared to the old method. Each feature will be discussed in its own subsection.

\subsubsection{Use of Layer Concentrations and Maximum-Layer SOFs}

The old-method SOF calculations were based on the whole-tank average concentrations of analytes. These were used as inputs to the ESP model, which calculated the equilibrium compositions of each of the phases. The new-method calculations are based on the concentrations of analytes in individual waste layers. The SOFs are calculated for each layer. Then the maximum SOF over all liquid layers in the tank is used to represent the liquid in the tank and the maximum SOF over all wet bulk solids layers is used to represent the solid in the tank.

The maximum-layer SOFs were preferred to SOFs based on the average composition because of concerns that the average did not conservatively represent the concentration variation within a tank's waste. An accident might involve only a portion of the waste in a tank, rather than the whole inventory, and that portion could come from a layer of waste that is more toxic than the average. Thus the maximum-layer SOFs are a more appropriate safety basis than were the averages.

\subsubsection{Using Analyte Phase Concentrations Taken Directly From the BBI}

In the old study, the concentrations of analytes in the liquid and dry-solid phases were determined by the ESP model. The predicted concentrations in the liquid did not always match the measured concentrations, where measurements were available. Concentrations in the dry solid could not be compared to measurements because the latter were always on a bulk-solids basis. However, the presence of differences between predicted and measured concentrations in the liquid suggests that there would also be differences in the dry-solid phase.

The new method uses the concentrations found in the BBI, back-calculating them from total inventory in a layer and the density and volume of the layer. These concentrations may be based from sample analyses, process knowledge, engineering templates, or other estimates, depending on how complete the data set is for the analyte. No chemical model is applied to modify the concentrations from those given in the BBI.

In some cases, the concentrations found in the BBI would be considered the better estimates to use for SOF calculation. This would be the case when the BBI concentration in both the bulk-solids and liquid phases is based directly on sample measurements and those measurements were above the minimum detection limit (MDL) for the analyte. In other cases, the ESP prediction could be the better estimate. 
This would apply to a liquid concentration derived from an MDL, since the MDL overestimates the true concentration. It would also apply when the concentration in one or both of the phases is based on an estimate. The ESP prediction of the concentration in the liquid would be thermodynamically consistent with the concentration in the bulk solids, whereas this would not necessarily be true of an estimated concentration.

For example, some B-Farm tanks contain sludge whose bulk solids $\mathrm{NO}_{2}$ concentration (estimated or measured) is said by the BBI to be much higher than the concentration in the liquid (estimated). This relationship implies a $\mathrm{NO}_{2}$ concentration difference between the sludge and supernatant phases that could not be sustained over the period that the tank has been inactive. In these cases the old liquid-phase SOFs, for which ESP predicted higher $\mathrm{NO}_{2}{ }^{-}$liquid-phase concentrations than were given in the BBI estimates, are probably closer to the in-tank conditions than the new SOFs.

Although the phase concentrations found in the BBI are not necessarily completely chemically consistent with each other, they are in a certain sense preferable to the more consistent concentrations that can be produced by chemical modeling based on BBI data. The Best Basis Inventory has been approved as the single tank-waste basis for safety and other calculations. In this regard it makes sense to use the BBI concentration data directly, rather than using re-interpretations of the concentrations that come from chemical modeling.

\subsubsection{Basing the $\mathrm{Cr}(\mathrm{VI}) / \mathrm{Cr}$ (III) Split on the BBI Wash Factor for Chromium}

The toxicity of the chromium in the Hanford tank waste depend strongly on whether its oxidation state is three or six, the latter being more toxic and far more soluble. In the old method, the split between the two oxidation states was determined by one of several methods, depending on what information was available. Where both liquid and bulk composition data were available in the BBI, a liquid tracer analyte $\left(\mathrm{NO}_{2}, \mathrm{Cl}\right.$, $\mathrm{K}$, or Cs-137) was used to estimate the average liquid volume fraction in the waste. ${ }^{1}$ This information allowed a calculation of the fraction of $\mathrm{Cr}$ that was present in the liquid. The soluble fraction of the $\mathrm{Cr}$ was assigned to $\mathrm{Cr}(\mathrm{VI})$ and the remainder to $\mathrm{Cr}(\mathrm{III})$, and this split was used as input to ESP. For the few tank wastes where hexavalent chromium measurements were included in the Tank Characterization Database (TCD), they were used for the split instead of the soluble fraction. In cases where bulk but not liquid composition data were available in the BBI, no soluble fraction could be calculated. For these tank wastes, the Cr was conservatively assumed to be $100 \% \mathrm{Cr}(\mathrm{VI})$, that being the more toxic oxidation state.

In the new SOF calculation method, the BBI water wash factor defined for $\mathrm{Cr}$ in each tank was used to split the solid-phase $\mathrm{Cr}$ between soluble $\mathrm{Cr}$, which was assigned to $\mathrm{Cr}(\mathrm{VI})$, and insoluble $\mathrm{Cr}$, which was assigned to $\mathrm{Cr}(\mathrm{III})$. All $\mathrm{Cr}$ in the liquid phase was treated as $\mathrm{Cr}(\mathrm{VI})$.

In the solids, $\mathrm{Cr}(\mathrm{III})=(1 \text {-washfactor })^{*} \mathrm{Cr}$, and $\mathrm{Cr}(\mathrm{VI})=$ washfactor* $\mathrm{Cr}$

In the liquid, $\mathrm{Cr}(\mathrm{III})=0$, and $\mathrm{Cr}(\mathrm{VI})=\mathrm{Cr}$

The water wash factor in the BBI reflects the fraction of an analyte that can be removed from bulk waste by water washing of the waste. For Cr, this fraction approximates the in-situ $\mathrm{Cr}(\mathrm{VI})$ fraction, or could possibly overestimate it if the experiment that obtained the water wash factor caused any $\mathrm{Cr}(\mathrm{III})$ to become oxidized to $\mathrm{Cr}(\mathrm{VI})$. 
The change in method was made in order to have a consistent $\mathrm{Cr}$ split method for all tanks. The contribution of $\mathrm{Cr}$ to the solid SOF could increase or decrease in the new method, compared to the old, depending on the value of the wash factor. $\mathrm{Cr}(\mathrm{VI})$ has been found to constitute nearly all the liquid-phase $\mathrm{Cr}$ in those liquid samples where both $\mathrm{Cr}$ and $\mathrm{Cr}(\mathrm{VI})$ have been measured, so assigning all the dissolved Cr to $\mathrm{Cr}(\mathrm{VI})$ would produce only a slight increase in the new-method liquid SOF, compared to the old method.

\subsubsection{Use of the ESP-Modeled Hydroxide Concentrations as Defaults}

In the old method, ESP calculated the $\mathrm{OH}$ ion concentration in the liquid that was chemically consistent with the average waste composition. In some cases, where the predicted $\mathrm{OH} / \mathrm{pH}$ differed substantially from the expected or measured value, the charge balance in the ESP inputs was adjusted iteratively, by spreadsheet calculations, to make the model predictions match the measurements more closely.

The new method calculates free $\mathrm{OH}$ default concentrations based on the liquid-phase free $\mathrm{OH}^{-}$ concentrations that were predicted by ESP for the year-2002 average tank waste in the study by Cowley et al. (2003). These default concentrations are used only when the BBIS does not provide any free $\mathrm{OH}^{-}$ concentration information for a layer.

The ESP-based liquid-phase free $\mathrm{OH}$ was assumed to include both the $\mathrm{OH}^{-}$ion, as predicted by the ESP model, and one mole of $\mathrm{OH}$ from each mole of $\mathrm{Al}(\mathrm{OH})_{4}{ }^{-}$complex predicted by ESP. This summation is consistent with the way in which free $\mathrm{OH}$ is measured during sample analysis. ${ }^{2}$ The free $\mathrm{OH}$ concentrations from Cowley et al. (2003) are whole-tank averages; therefore all of a tank's liquid layers that lack BBI-S free $\mathrm{OH}$ data are given the same default free $\mathrm{OH}$ concentration.

In the new method, when a wet bulk solids layer does not have a BBI-S free $\mathrm{OH}$ value, the default concentration of free $\mathrm{OH}$ is estimated by multiplying the current $\mathrm{BBI}$ concentration of $\mathrm{NO}_{2}{ }^{-}$in the layer by the free $\mathrm{OH} / \mathrm{NO}_{2}{ }^{-}$ratio that was predicted by ESP in 2002 for the average liquid in the tank. This approach assumes that free $\mathrm{OH}$ and $\mathrm{NO}_{2}{ }^{-}$are both present only in the liquid phase, and that the ratio between them is the same in the waste liquid in every layer of the tank as it was in the tank average liquid in 2002. Although this tank-average ratio would not necessarily represent every waste layer accurately, it is the only hydroxide-related information that is available for all tanks. Barring intervention, free $\mathrm{OH}$ concentrations decrease over time because of $\mathrm{CO}_{2}$ absorption from the air, tending to make the 2002 estimate conservative for current wastes. In tanks where sodium hydroxide is added to control $\mathrm{pH}$, the outcome would be monitored by sampling and the results would be reflected in BBI updates.

The ratio uses $\mathrm{NO}_{2}{ }^{-}$as a basis because the BBI provides an estimate for $\mathrm{NO}_{2}{ }^{-}$in all waste layers (thus the layer data needed are always available) and $\mathrm{NO}_{2}{ }^{-}$is never present at high enough concentrations to bias the ratio by precipitation (nor are nitrite solids present that could dissolve and bias the free-OH/ $\mathrm{NO}_{2}{ }^{-}$ratio in the bulk solids layer). Because nitrite is a major analyte, meaning that it is always included in the BBI

1 Liquid tracer species are expected to be completely soluble (at their actual concentrations in the waste) and are used to estimate the amount of liquid in a wet solid.

2 In the liquid portion of tank waste sample, aluminum is present almost entirely as $\mathrm{Al}(\mathrm{OH})_{4}{ }^{-}$complex. The aluminum in a sample is precipitated as neutral $\mathrm{Al}(\mathrm{OH})_{3}$ during the preparation of the sample for hydroxide measurement, causing one mole of $\mathrm{OH}^{-}$to be freed from the complex. Thus, the measured free $\mathrm{OH}$ includes both the in-situ free $\mathrm{OH}$ and a contribution from hydroxide that was originally part of the Al complex. Other metals may also be found in solution as hydroxide complexes, potentially contributing to the analyzed free hydroxide, but these contributions are relatively small and are neglected. 
for every layer in every tank, the method outlined above can provide a free $\mathrm{OH}$ estimate for both phases in every tank.

Appendix $\mathrm{C}$ contains the default free $\mathrm{OH}$ concentrations to be used for the liquid phase in any Hanford tank waste layer for which there is no $\mathrm{BBI}$ free $\mathrm{OH}$ data. The appendix also includes the liquid-phase $\mathrm{NO}_{2}{ }^{-}$ion concentrations predicted by the ESP model in 2002. The ESP-based liquid-phase $\mathrm{NO}_{2}{ }^{-}$ concentration includes the predicted $\mathrm{NO}_{2}{ }^{-}$ion itself, the predicted $\mathrm{NaNO}_{2}$ complex in solution, and the $\mathrm{NaNO}_{2}$ solid that ESP mispredicted to exist in some tanks and that belonged in the liquid phase. (As noted in Section 2.1, ESP underestimated the solubility of $\mathrm{NaNO}_{2}$ under some conditions, hence the recalculation of liquid $\mathrm{NO}_{2}{ }^{-}$concentration as including the $\mathrm{NaNO}_{2}$ that ESP put into solid phase.)

The predicted $\mathrm{NO}_{2}{ }^{-}$is used as a liquid tracer to calculate the default free $\mathrm{OH}^{-}$in bulk solids phases where no BBI-S data are available. The equation used is

Wet Bulk Solids $\mathrm{OH}=(\mathrm{ESP}$ liquid $\mathrm{OH}) \frac{\text { Wet Bulk Solids } \mathrm{NO}_{2} \text { from } \mathrm{BBI}}{\text { ESP liquid } \mathrm{NO}_{2}}$

Any discrepancies between the 2002 hydroxide calculations and the currently existing hydroxide will be of concern only for those waste layers for which the BBI does not include free $\mathrm{OH}$ inventories. As of May 2006, free $\mathrm{OH}$ inventories in one or more liquid phases are included in the BBI for at least some layers in

- all the DSTs;

- A-101 through A-103, AX-101, BY-103, BY-105, BY-106, C-106;

- S-101, S-103, S-104, S-106, S-108, S-109, S-111, SX-101 through SX-106, T-101, T-102, TX-112, TX-113, TX-115, TX-116, TX-118, TY-102, TY-103, U-102, U-103, U-105 through U-109, U-111; and

- the four U-200 tanks.

Free OH inventories in the wet bulk solid phases are present in the May 2006 BBI for at least some layers in

- AN-102 through AN-107, AP-102, AP-105, AW-101, AW-103, AW-105, AW-106, AZ-101, AZ-102, SY-102, and SY-103;

- S-101, S-102, S-103, S-107, S-108, S-109, S-111, S-111, S-112, SX-102, SX-103, SX-105, SX-106, TY-102, TY-103, TY-105, U-103, U-109, and U-111.

Perhaps arguably, this list of cases where the default free $\mathrm{OH}$ concentration data will not be needed includes most of the tanks in which activity requiring specific safety analyses is likely to occur. The free $\mathrm{OH}$ data for these and other tanks will be updated as a result of compatibility requirements as new operations are planned, which will update the concentrations in the BBI that will be used instead of the defaults. The use of $\mathrm{OH}^{-}$and $\mathrm{NO}_{2}{ }^{-}$data from Cowley et al. (2003) is therefore considered an acceptable approximation. 


\subsubsection{Charge Balance Effects}

The old method provided a charge-balanced combination of ESP-modeled (major) analytes. The trace analytes were then included in this composition in the form of compounds, which frequently were sodium and potassium salts. This additional $\mathrm{Na}$ and $\mathrm{K}$ was offset by reducing the major sodium salts $\mathrm{NaOH}$, $\mathrm{NaNO}_{2}$, and $\mathrm{NaNO}_{3}$, a step that tended to reduce the old-method SOF (as is detailed below).

The trace compounds were neutral compounds and therefore inherently charge-balanced, but their addition tended to increase the concentrations of sodium and potassium in the waste composition above the BBI values. To reduce the excess of sodium and potassium in the liquid phase, the $\mathrm{Na}$ and $\mathrm{K}$ that were associated with two of the trace analytes (HEDTA and EDTA) were subtracted from the total liquidphase $\mathrm{Na}$ and $\mathrm{K}$ given in the ESP output. The result was to decrease the amount of sodium and potassium that were available to be assigned to sodium nitrite, nitrate, and hydroxide and to potassium nitrite, nitrate, and hydroxide.

Taking sodium as an example, the process followed by the old method was this:

TempNa $=\left[\mathrm{Na}^{+}\right]+[$sum of assorted contributions of Na from species predicted by the ESP model $]$ - [sum of Na needed by anionic species that are split between Na and K using NaRatio] $-4 *$ NaRatio*[EDTA] $-3 *$ NaRatio* [HEDTA]

Here, TempNa was an intermediate Na concentration variable that included the effects of mass-balance accounting on $\mathrm{Na},[\mathrm{Na}+]$ was the molar concentration of sodium ion in solution predicted by ESP, and [EDTA] and [HEDTA] were the molar concentrations of the two trace analytes. The concentrations of $\mathrm{NaNO}_{2}, \mathrm{NaNO}_{3}$, and $\mathrm{NaOH}$ were then calculated as

$\left[\mathrm{NaNO}_{2}\right]=\left[\mathrm{NaNO}_{2}\right.$ complex in solution $]+$ TempNa $*\left(\left[\mathrm{NO}_{2}{ }^{-}\right.\right.$in solution $\left.] /\left[\mathrm{NO}_{2}{ }^{-}+\mathrm{NO}_{3}{ }^{-}+\mathrm{OH}^{-}\right]\right)$

$\left[\mathrm{NaNO}_{3}\right]=\left[\mathrm{NaNO}_{3}\right.$ complex in solution $]+$ TempNa $*\left(\left[\mathrm{NO}_{3}{ }^{-}\right.\right.$in solution $\left.] /\left[\mathrm{NO}_{2}{ }^{-}+\mathrm{NO}_{3}{ }^{-}+\mathrm{OH}^{-}\right]\right)$

$[\mathrm{NaOH}]=$ TempNa $*\left(\left[\mathrm{OH}^{-}\right.\right.$in solution $\left.] /\left[\mathrm{NO}_{2}{ }^{-}+\mathrm{NO}_{3}{ }^{-}+\mathrm{OH}^{-}\right]\right)$

The equation has been somewhat simplified to clarify the effect of the Na consumption caused by the trace analytes. The sodium that was subtracted from TempNa was made unavailable for sodium nitrate, nitrite, and hydroxide. This often decreased the SOF by reducing the concentration of the three anions' salts, in that the toxicity of EDTA and HEDTA salts was less than that of sodium nitrite and hydroxide.

The new method does not include the organic salts in question (Section 3.1) and therefore, all other factors being equal, the SOFs calculated by the new method are likely to be higher.

\subsubsection{Different Choice of Phase Densities}

When converting concentrations from $\mu \mathrm{g} / \mathrm{g}$ to $\mu \mathrm{g} / \mathrm{mL}$ or vice versa, the old method used the ESPcalculated densities for the liquid and dry-solid phases of the average waste in a tank. The new method, being based directly on BBI data, uses the densities that are part of the BBI database for each layer (also known as a component). The difference in the basis densities can affect the concentrations used for SOF calculation. 
The first step in units conversion is made during the generation of SOFProgram concentration input. The analyte concentrations that come from the BBI are converted to SOFProgram concentration inputs as described in Section 3.3.1: the layer (component) densities and volumes are used to convert the inventories in each solid layer to $\mu \mathrm{g} / \mathrm{g}$ concentrations, and the layer volumes are used to convert the inventories in each liquid layer to $\mu \mathrm{g} / \mathrm{mL}$ concentrations. The analyte concentrations that come from the trace metal and $\mathrm{OH}$ default concentration input are already in the input units required by SOFProgram, $\mu \mathrm{g} / \mathrm{g}$ for solids layers and $\mu \mathrm{g} / \mathrm{mL}$ for liquid layers. For default concentrations, therefore, no unit conversion is needed at this step.

In the final units conversion step, the component density input is used within SOFProgram to convert the solid-phase concentration inputs from the received units of $\mu \mathrm{g} / \mathrm{g}$ to the units required for SOF calculation, $\mathrm{mg} / \mathrm{m}^{3}$.

The use of BBI-based rather than ESP-predicted densities is unavoidable, if BBI concentrations are to be used directly. 



\subsection{Comparison of Results for New and Old Methods}

As discussed in Section 3, the several ways in which the new SOF calculation method was changed compared to the old method can be expected to affect the SOFs in various ways. The overall effect may be either an increase or decrease for any particular tank, phase, and TEEL level; the direction cannot be predicted a priori. Therefore, a systematic comparison of the SOFs calculated by the new and old methods is needed in order to evaluate the effects of the method change.

This report focuses on the replacement of ESP modeling by the direct use of BBI data. The method comparison therefore considers only the handling of those "non-trace" analytes that were originally modeled using the ESP code, as defined in Section 2.1, not the "trace" analytes that were included in the SOF in a different manner. The discussion of the contributions of "trace" analytes is deferred to another document (Meacham et al. 2006).

\subsection{Basis for Method Comparison}

The new and old methods cannot be compared unless both are applied on the same basis. Because the old method depended on BBI data as of May 2002, the new-method inputs were derived from that inventory. In addition, the old method SOF Program runs were redone with the same TEELs (Rev. 21A) used in the new method. This ensured that all differences in results were caused by method changes alone.

The change from dry-solid basis, in the old method, to wet bulk solids basis, in the new method, causes some difficulty in comparing solid-phase results. To improve comparability, the old method's solid SOF results were converted to a wet bulk solid basis. The volume fraction of dry solid phase in the average wet bulk solids in a tank was calculated using the following equation:

$$
\phi_{S}=\frac{V \phi_{E S P}}{V-V_{D L}}
$$

where $\phi_{\mathrm{S}}=$ dry-solid volume fraction in wet bulk solids

$\phi_{\mathrm{ESP}}=$ ESP-predicted dry-solid fraction, average of all the waste in the tank

$\mathrm{V}=$ The total waste volume in the tank as defined by the BBI

$\mathrm{V}_{\mathrm{DL}}=$ The total volume of liquid that the BBI explicitly defines as being liquid, separate from the liquid that is present only implicitly as part of the bulk solids; $\mathrm{V}_{\mathrm{DL}}$ is the sum of supernatant, drainable sludge liquid, and drainable saltcake liquid

The numerator of the fraction is the dry solid volume in the tank, and the denominator is the total volume of all the layers of wet bulk solids (including both dry solid and non-drainable interstitial liquid volume). The solid volume fraction calculated by the above equation is approximate because of uncertainty in the parameters and because retained gas volume is not accounted for. The combination of ESP-predicted total liquid in the tank with independently-estimated volumes also adds an uncertainty. Table D.1 in Appendix D shows the solid fractions that were used.

Wet bulk solid SOFs are calculated from the old method's dry-solid and liquid SOFs as the volumeweighted average: 
Wet Bulk Solid SOF $=\phi_{S} *$ Dry Solid SOF $+\left(1-\phi_{S}\right) *$ Liquid SOF

Because there are inherent differences between the ESP-based solid fraction, $\phi_{S}$, of Eq. (4.2) and the unspecified value for solid fraction in the BBI, the comparison between new and old methods for the wet bulk solid phase SOFs is less exact than the comparison of the liquid phase SOFs.

\subsection{Overall Comparison of Major-Analyte SOFs Calculated by Old and New Methods}

As already noted, this report considers only the major (non-trace) analytes. Accordingly the SOFs discussed here are the sums of the contributions made by major-analyte compounds alone. Trace contributions are not included and the TEELs have been updated; therefore the old-method SOFs shown in this report are not the same as those given by Cowley et al. (2003).

Figure 4.1 shows old and new liquid-phase SOFs for each of the three TEEL levels of concern, TEEL-1, TEEL-2, and TEEL-3. The figure includes SOFs for all 177 tanks, grouped by DSTs (left), 100-SSTs (center), and 200-SSTs (right). The tanks are arranged along the x-axis in order of increasing old-method SOF, within the tank group. Note that the tanks are not in the same sequence for all three TEELs, so a location on the $\mathrm{x}$-axis does not indicate the same tank on all three plots.

The y-axis is the SOF value. (In the y-axis label, “SOF-1", "SOF-2”, "SOF-3" are abbreviations for the SOF based on TEEL-1, TEEL-2, or TEEL-3, respectively) The solid lines in the figures represent the old-method tank SOFs; the hollow boxes are the new-method SOFs for the corresponding tanks. For tanks where the BBI does not define any liquid phase, there are no new-method points. The 100-SST and 200-SST that had the bounding SOF-1 and SOF-2 values, according to the old method, are among those that have no new-method point because there is no BBI-defined liquid phase.

Certain features of the change in method can be seen in Figure 4.1. The differences between old and new SOFs are generally smaller for the DSTs than for the other groups of tanks, although many of the tanks at the high-SOF end of the 100-SST range also have old and new-method SOFs that are very similar. The differences generally become more positive as the TEEL level increases; the resulting increase in scatter (in the absolute magnitude of the change) is evident, based on comparing the TEEL-3 figure to those for TEEL-1 or TEEL-2. A discussion of the causes of the differences is deferred to a later section.

Table 4.1 lists how many of the tanks in each group are found in different parts of the difference range. In the table, the percent difference is expressed in terms of (new - old)/old. 

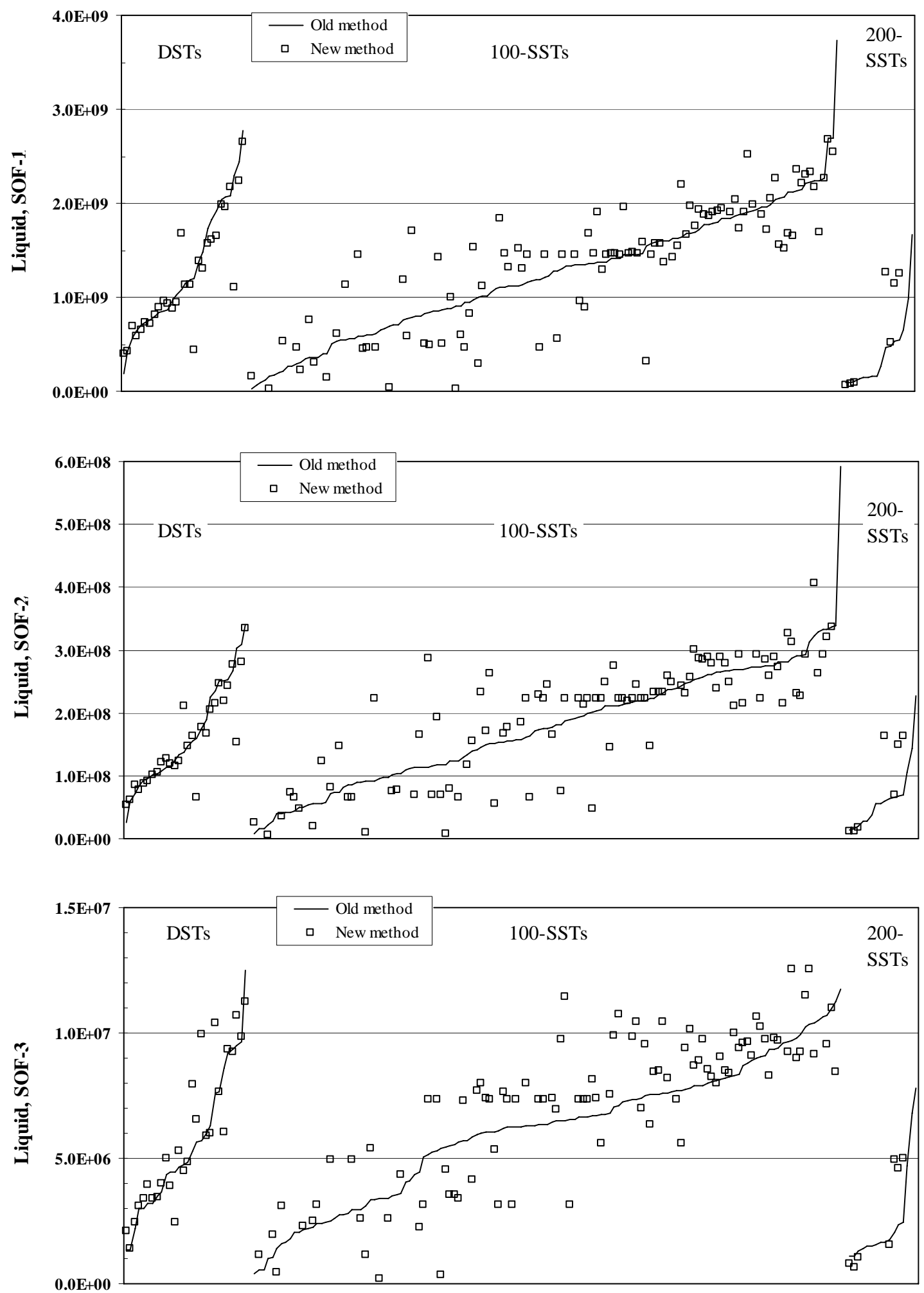

Figure 4.1. Comparison of Old and New Liquid-Phase SOFs for TEEL-1, -2, and -3 
Table 4.1. Differences Between Old and New Liquid-Phase SOFs for TEEL-1, -2, and -3

\begin{tabular}{|c|c|c|c|}
\hline \multirow[b]{2}{*}{ (New-Old)/Old } & \multicolumn{3}{|c|}{ DST } \\
\hline & TEEL-1 & TEEL-2 & TEEL-3 \\
\hline$-100 \%$ to $-50 \%$ & 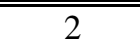 & 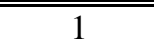 & 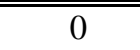 \\
\hline$-50 \%$ to $-20 \%$ & 0 & 1 & 2 \\
\hline$-20 \%$ to $0 \%$ & 16 & 14 & 7 \\
\hline $0 \%$ to $+20 \%$ & 7 & 10 & 14 \\
\hline$+20 \%$ to $+50 \%$ & 1 & 0 & 3 \\
\hline$+50 \%$ to $+100 \%$ & 1 & 1 & 2 \\
\hline$>+100 \%$ & 1 & 1 & 0 \\
\hline \multirow[b]{2}{*}{ (New-Old)/Old } & \multicolumn{3}{|c|}{ 100-SST } \\
\hline & TEEL-1 & TEEL-2 & TEEL-3 \\
\hline$-100 \%$ to $-50 \%$ & 8 & 8 & 5 \\
\hline$-50 \%$ to $-20 \%$ & 17 & 15 & 11 \\
\hline$-20 \%$ to $0 \%$ & 17 & 15 & 14 \\
\hline $0 \%$ to $+20 \%$ & 35 & 41 & 35 \\
\hline$+20 \%$ to $+50 \%$ & 8 & 7 & 23 \\
\hline$+50 \%$ to $+100 \%$ & 5 & 6 & 7 \\
\hline$>+100 \%$ & 6 & 4 & 1 \\
\hline \multirow[b]{2}{*}{ (New-Old)/Old } & \multicolumn{3}{|c|}{ 200-SST } \\
\hline & TEEL-1 & TEEL-2 & TEEL-3 \\
\hline$-100 \%$ to $-50 \%$ & 0 & "0 & 0 \\
\hline$-50 \%$ to $-20 \%$ & 1 & 2 & 2 \\
\hline$-20 \%$ to $0 \%$ & 2 & 1 & 2 \\
\hline $0 \%$ to $+20 \%$ & 1 & 1 & 0 \\
\hline$+20 \%$ to $+50 \%$ & 0 & 0 & 0 \\
\hline$+50 \%$ to $+100 \%$ & 0 & 0 & 1 \\
\hline$>+100 \%$ & 3 & 3 & 2 \\
\hline
\end{tabular}

Table 4.2 and Figure 4.2 provide a similar overview of the differences in wet bulk solid SOF that are caused by the change in method. Figure 4.3 shows the wet bulk solids SOF-2 and SOF-3 values with an expanded y-axis that shows more details of the lower values. The trends are much the same for wet bulk solids as for liquid, except that the DSTs show more scatter (mostly upward) for solids than for liquid, while the SSTs show less. Relatively few tanks have a new-method SOF that is less than the old-method SOF by more than $20 \%$ of the old value.

Considering all three TEEL levels, 50 to $60 \%$ of the Hanford tanks had SOFs for which the new method is within $\pm 20 \%$ of the old method, while 15 to $20 \%$ of the tanks show a difference of more than $\pm 50 \%$. The SOFs are increased by the new method more often than they are decreased. These statements hold for both the liquid and wet bulk solids SOFs. Only twelve tanks (less than ten percent of the tanks) had SOFs that decreased by more than $50 \%$. Of these, only one had wet bulk solid SOFs that decreased by more than 50\%; the other major decreases were all in liquid-phase SOFs.

For perspective, an uncertainty of $20 \%$ in analyte concentrations is a reasonable expectation for compositions based on sample measurements, considering the uncertainties in sample concentration and density analyses and the variability of concentration within the waste. The overall uncertainty might be 
considerably greater in tanks that have not been sampled, for which the composition is based on process knowledge or a template (Place and Higley 2005).

Table 4.2. Differences Between Old and New Wet Bulk Solids SOFs for TEEL-1, -2, and -3

\begin{tabular}{|c|c|c|c|}
\hline \multirow[b]{2}{*}{ (New-Old)/Old } & \multicolumn{3}{|c|}{ DST } \\
\hline & TEEL-1 & TEEL-2 & TEEL-3 \\
\hline$-100 \%$ to $-50 \%$ & 1 & 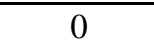 & 0 \\
\hline$-50 \%$ to $-20 \%$ & 1 & 1 & 3 \\
\hline$-20 \%$ to $0 \%$ & 4 & 5 & 9 \\
\hline $0 \%$ to $+20 \%$ & 5 & 5 & 4 \\
\hline$+20 \%$ to $+50 \%$ & 4 & 6 & 4 \\
\hline$+50 \%$ to $+100 \%$ & 4 & 3 & 0 \\
\hline$>+100 \%$ & 1 & 0 & 0 \\
\hline \multirow[b]{2}{*}{ (New-Old)/Old } & \multicolumn{3}{|c|}{ 100-SST } \\
\hline & TEEL-1 & TEEL-2 & TEEL-3 \\
\hline$-100 \%$ to $-50 \%$ & 0 & 0 & "0 \\
\hline$-50 \%$ to $-20 \%$ & 3 & 2 & 0 \\
\hline$-20 \%$ to $0 \%$ & 41 & 39 & 29 \\
\hline $0 \%$ to $+20 \%$ & 51 & 44 & 54 \\
\hline$+20 \%$ to $+50 \%$ & 19 & 32 & 25 \\
\hline$+50 \%$ to $+100 \%$ & 13 & 8 & 13 \\
\hline$>+100 \%$ & 6 & 8 & 12 \\
\hline \multirow[b]{2}{*}{ (New-Old)/Old } & \multicolumn{3}{|c|}{ 200-SST } \\
\hline & TEEL-1 & TEEL-2 & TEEL-3 \\
\hline$-100 \%$ to $-50 \%$ & 0 & 0 & 0 \\
\hline$-50 \%$ to $-20 \%$ & 2 & 5 & 2 \\
\hline$-20 \%$ to $0 \%$ & 9 & 3 & 4 \\
\hline $0 \%$ to $+20 \%$ & 5 & 3 & 8 \\
\hline$+20 \%$ to $+50 \%$ & 0 & 4 & 0 \\
\hline$+50 \%$ to $+100 \%$ & 0 & 0 & 1 \\
\hline$>+100 \%$ & 0 & 1 & 1 \\
\hline
\end{tabular}



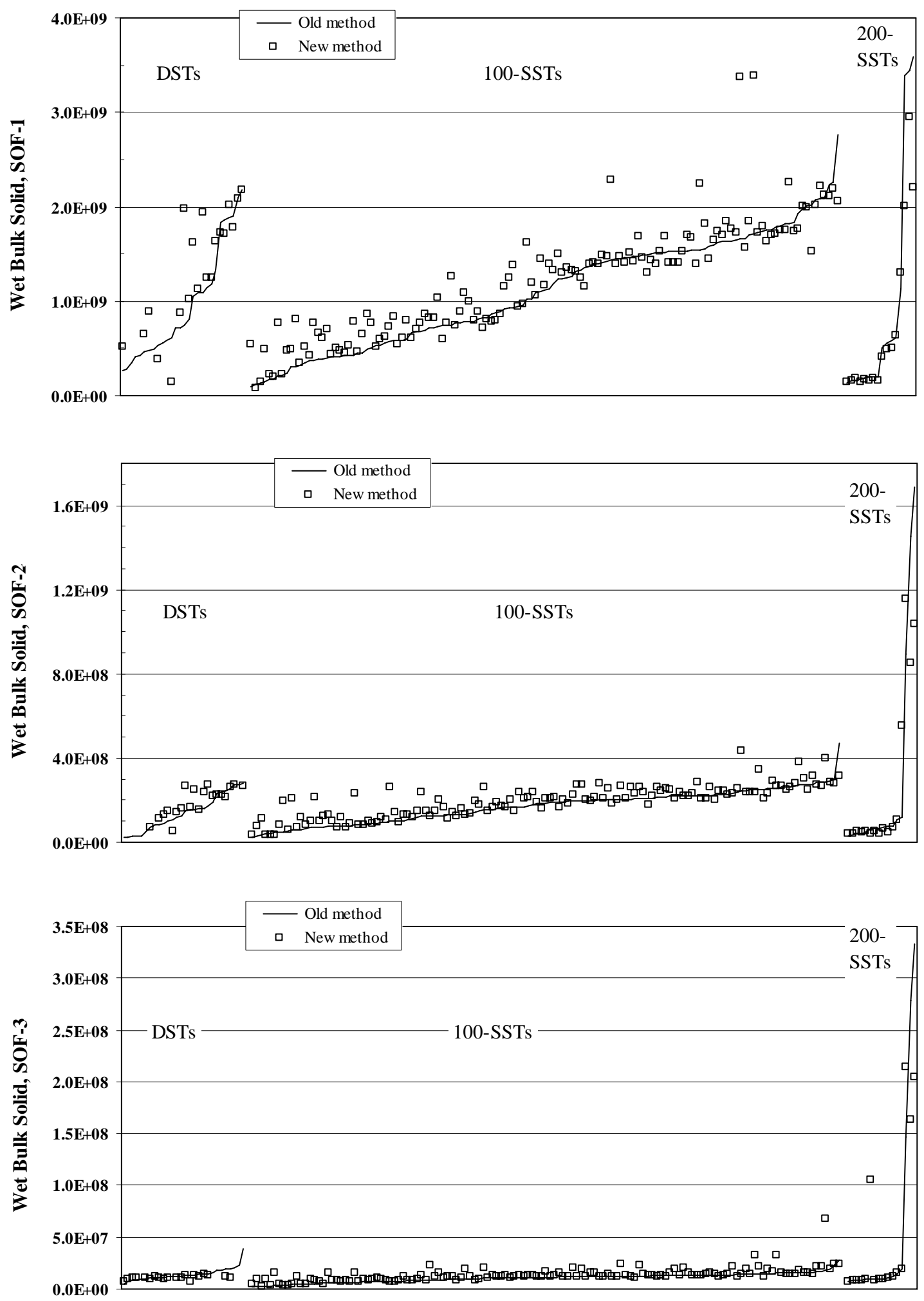

Figure 4.2. Comparison of Old and New Wet Bulk Solids SOFs for TEEL-1, -2, and -3 

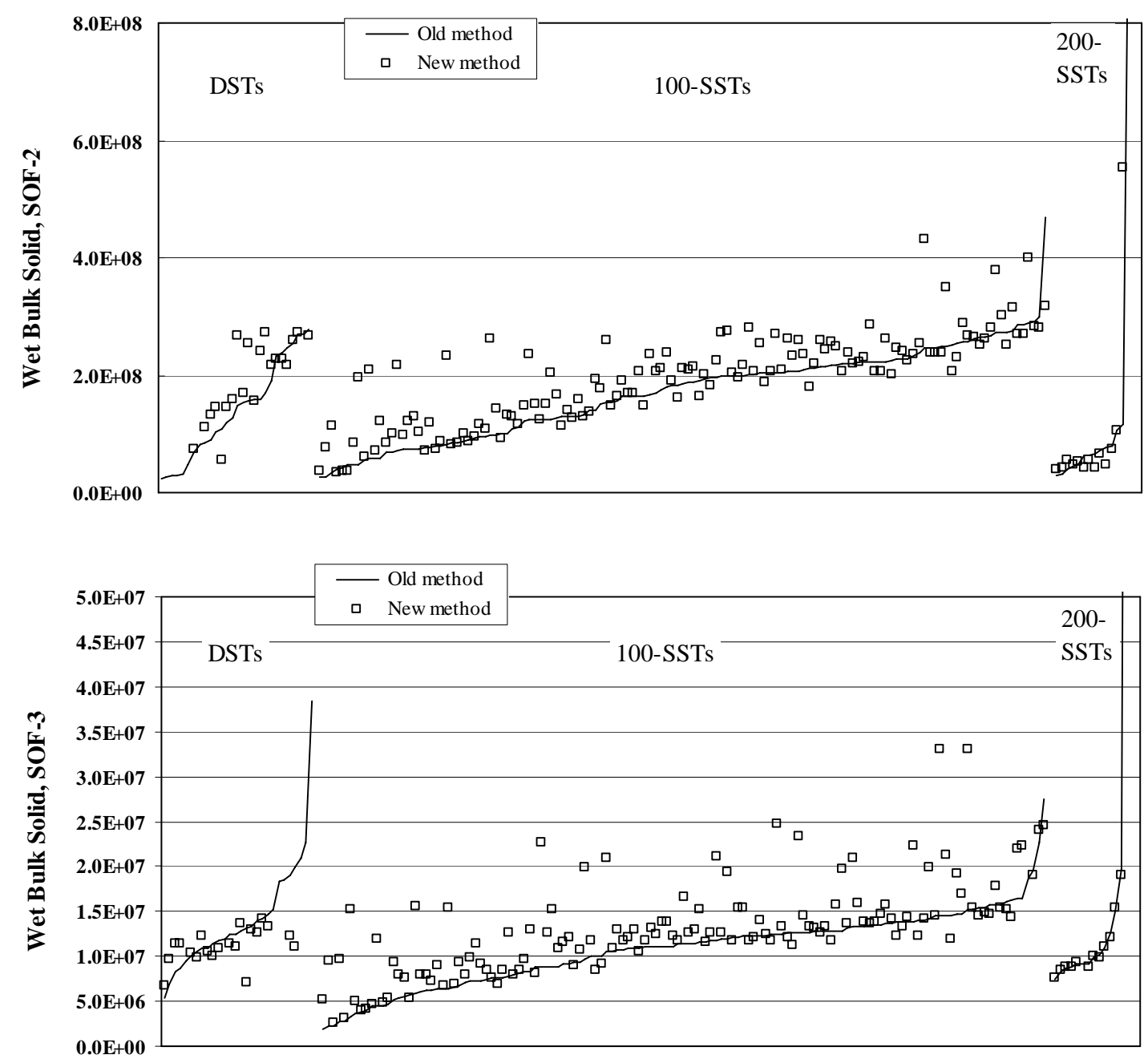

Figure 4.3. Comparison of Old and New Wet Bulk Solids SOFs for TEEL-2 and -3 (y-axis expanded, compared to Figure 4.2)

\subsection{Detailed Evaluation of Changes in Major-Analyte Liquid-Phase SOFs}

Because the SOF-3 values showed greater difference between old and new methods, they were used as the basis for a detailed investigation of the causes of the differences produced by the change in methods. In each case where the liquid-phase SOF-3 change was relatively large, defined as an increase or decrease of more than $30 \%$ - that is, a change rounding to $31 \%$ or more - the analytes were identified that jointly produced $80 \%$ or more of the overall change in the SOF. Every analyte that contributed more than $10 \%$ of a large change was considered.

For each selected analyte, three ratios were calculated:

- new-method analyte contribution to the SOF-3 / old-method contribution;

- new-method analyte concentration in the liquid / old-method concentration;

- new-method analyte effective TEEL-3 value / old-method value. 
The effective TEEL by dividing the total analyte concentration by the total analyte SOF contribution). Because an analyte may be distributed into more than one compound, each of which has its own TEEL, the effective TEEL is needed as a measure of the weighted average toxicity of the analyte, accounting for all the compounds in which it is present. As is the case for the compound TEELs, a lower effective TEEL indicates higher toxicity and vice versa.

The ratio of new to old contributions shows how much the analyte's contribution to the TEEL-3 liquid SOF changed because of the change in method. The ratio of concentrations and the ratio of effective TEELs allow a distinction to be made between those contribution changes that result from concentration changes (for example, different estimates of solubility) and those that arise from toxicity changes (different assigned compounds). The method changes described in Section 3.1 produce toxicity changes. Those described in Sections 3.2 and 3.3 produce concentration changes.

Table 4.3 (located at the end of this subsection) assembles the information related to liquid-phase SOF decreases of more than $30 \%$. For each of the 14 tanks for which such a decrease occurred, the table shows the old and new SOF-3 values and their ratio, as well as data for the significant analytes.

"Significant analytes" were those that individually caused $10 \%$ or more of the change in SOF-3. For each of these significant analytes, the table shows the ratio of new to old contributions ("New/Old Contrib-3 ratio"), the ratio of new to old concentrations, and the ratio of new to old effective TEELs. Some ratios are stated as "undefined" because the concentration in the old or new method was zero (giving a divideby-zero error). The table also includes the fraction of the SOF decrease that comes from each analyte (the fractions do not sum to $100 \%$ because only the significant analytes are included). This last number is negative when the analyte's contribution increased (i.e., a negative decrease). The reason for the change in the analyte contribution is also listed.

In all cases, the major decreases in the liquid SOF-3 were caused by differences between the ESPpredicted analyte solubilities and those implied by the liquid-phase concentrations in the BBI. The differences in predicted and BBI liquid concentrations were observed by comparing the ESP output liquid concentrations to BBI values averaged over all liquid layers. As discussed in Section 3.3.2, it is not possible to make a general statement about whether the ESP prediction or the BBI is more accurate.

Consider the five tanks (B-111, B-110, T-110, C-110, and TX-117) in which the liquid SOF-3 decreased by more than $50 \%$ from the old to the new method. In all five cases the predominant cause of decrease was a lower solubility of $\mathrm{NO}_{3}$ and/or $\mathrm{NO}_{2}$ in the $\mathrm{BBI}$ liquid, compared to the ESP prediction. In two of these tanks, the liquid-phase concentrations in the BBI were estimated from historical or template information. In three tanks, the bulk-solid-phase concentrations in the BBI were estimated. In only one of the five tanks were both the liquid-phase and solid-phase concentrations in the BBI based on measurements. In the cases of B-111 and B-110, there seems to have been an inconsistency between the $\mathrm{NO}_{3}$ and $\mathrm{NO}_{2}$ concentrations in the liquid, which were estimates, and the measurement-based bulk-solid concentrations in the year-2002 BBI. In other cases, such as C-110, the 2002 BBI was based completely on measured concentrations; this suggests that ESP's thermodynamic database did not describe the tank's chemistry well.

In tanks such as C-204, where both the liquid and solid-phase concentrations were based on measurements, it is quite likely that the new method (being data-based) is more accurate than the old. In some other tanks - for example, B-110 and B-111 - SOF calculations would be more accurate if the ESP model were used, because of apparent inconsistencies between the compositions of the liquid and bulk- 
solids phases as given by the estimates used in the BBI. However, the same uncertainties and approximations that cause the inter-phase inconsistencies also affect the accuracy of the inputs to the ESP model. This being the case, it is not clear how much improvement the additional step of thermodynamic equilibrium calculation would provide.

There was no case in which a decrease in the effective toxicity of analytes caused the new-method SOF-3 to be more than $2 \%$ less than the old-method SOF. In particular, the decrease in liquid-phase lead toxicity produced by assigning lead to hydrogen lead oxide compounds instead of lead nitrite (Section B.16) had a trivial effect. Even at SOF-3, where the decrease in Pb toxicity is more than two orders of magnitude, the change in the $\mathrm{Pb}$ toxicity never caused a decrease of as much as $0.5 \%$. Lead is not a significant toxic contributor in tank waste liquids.

Table 4.4 contains the information related to liquid-phase SOF increases of more than $30 \%$. Three aspects of the change in SOF calculation method are the causes of the major increases in liquid-phase SOFs:

- In 16 tanks, the differences in SOFs were primarily due to differences between the ESP-predicted and BBI solubilities of analytes (most often $\mathrm{NO}_{3}, \mathrm{NO}_{2}, \mathrm{OH}$, and $\mathrm{Al}$ ), as was also the case for the major decreases in liquid SOFs (note that this cause was about as likely to produce SOF-3 increases as decreases);

- In 3 tanks, the differences were primarily due to the use of analyte concentrations from the maximumSOF layer, as discussed in Section 3.3.1; and

- In 5 tanks, the differences were primarily due to an increase in the effective toxicity of one analyte (TOC), as discussed in Section 3.1.

In a few cases, the concentration of an analyte changed because of both solubility differences and the use of maximum-SOF layer concentrations. The effect of solubility difference was judged by comparing the ESP-predicted concentration with the average concentration over all liquid layers in the BBI, while the effect of maximum-layer concentrations was evaluated by comparing the layer concentration to the average liquid concentration. If the latter effect produced a greater increase than the former, then the maximum-layer concentration was given in the table as the reason for the change.

A complicating factor appears in tanks S-109 and BY-101. When these two tanks were modeled in 2002 with ESP, the model could not be made to converge on the BBI-average composition. Convergence was obtained by diluting the waste composition with water. Thus, for these two tanks part of the difference between ESP and BBI solubility came from the waste dilution used for ESP, which would have increased the amount of liquid and decreased the concentrations of completely-dissolved analytes such as $\mathrm{Cr}(\mathrm{VI})$, free $\mathrm{OH}$, and $\mathrm{NO}_{2}$. This effect accounts for a portion of the increase in SOF from the old to the new method, and in these cases the new method more accurately reflects the waste compositions.

The increase in the effective toxicity of TOC resulted from assigning sodium and potassium oxalate as the TOC compounds. In the ESP runs, the TOC concentration in the BBI was split into a dissolved fraction, which was input to ESP as acetate, and a precipitated fraction, which was input as oxalate. In most tanks, the TOC in the liquid was predicted to consist primarily of acetate. In the new method, all TOC is oxalate, including that in the liquid. Because oxalate is a more toxic form of TOC than acetate, the effective toxicity of the TOC (particularly of TOC in the liquid) was increased by the new method. 
Section B.22 in Appendix B contains more information on the selection of oxalate salts as the assigned TOC compounds.

\subsubsection{Effect on Liquid-Phase SOFs of Using Default Hydroxide Concentrations}

To estimate the effect of using the default hydroxide concentrations, a comparison was run in which the new method was used with default hydroxide only. In other words, those layers for which the BBI contained free hydroxide concentrations were assigned the default concentrations instead, based on the 2002 ESP predictions as described in Section 3.3.4. The resulting SOFs were compared to those calculated by the standard new method, in which BBI data (when available) were preferred to default. In the 2002 BBI there were 91 liquid layers for which a comparison could be made, out of a total of 174 liquid layers.

Using the default instead of the BBI OH concentration usually did not cause either increases or decreases of more than $10 \%$ in the SOFs. Seven tanks, out of the 60 for which BBI OH data were available, showed SOF decreases of more than $10 \%$. The maximum decrease seen was $20 \%$, which occurred in BY-105 liquid at TEEL-3. Thirteen tanks showed increases of more than $10 \%$. Most of these increases were between $10 \%$ and $36 \%$. The exceptions were layers in AY-102 and AW-104, where the use of default $\mathrm{OH}$ caused increases of between $80 \%$ and $630 \%$, depending on the TEEL level. In most cases, the changes in SOF-1 and SOF-2 were smaller in magnitude than the change in SOF-3. Overall, the effect of default versus measured $\mathrm{OH}$ was not significant in liquids.

\subsection{Detailed Evaluation of Changes in Major-Analyte Wet Bulk Solids SOFs}

The largest changes in the wet bulk solids SOF-3s were analyzed in the same manner as the liquid-phase SOF-3s, defining a change of $30 \%$ or more as a major change. Tables 4.5 and 4.6 show the old and new SOF-3 values, their ratios, and data for the significant analytes. Table 4.5 contains information for the tanks in which the SOF-3 decreased by more than $30 \%$ and Table 4.6 describes the tanks that had SOF-3 increases of more than $30 \%$. Five tanks fell into the "decrease" category and forty-five into the "increase" category.

Several aspects of the change in SOF calculation method are the causes of the major changes in bulk wet solids SOFs:

- In 37 of the major increases, the primary cause was the use of the concentrations of the maximumSOF layer;

- In all 5 of the major SOF-3 decreases and one of the increases, the primary cause was a combination of solubility changes (ESP versus BBI) with inaccuracies in the estimation method for the old-method solid volume fraction;

- In 4 of the increases, the primary cause was an increase in the toxicity of $\mathrm{Pb}$;

- In 2 of the increases, the primary cause was an increase in the toxicity of TOC; and

- In one of the increases, the primary cause was charge-balance adjustments made to the ESP output composition in the old method. 
The above list makes it appear that differences between ESP and BBI solubilities are not as important for wet bulk solids as they were for liquids. This is partly true; bulk solids contain both liquid and dry solid and the effect of solubility changes alone is offset by the presence of solid. Nevertheless, the apparent lack of effect of solubility is somewhat misleading.

Suppose, for example, the ESP model predicted lower solubility for an analyte than was seen in the BBI. This solubility difference would tend to increase the old-method analyte concentration in the dry-solid phase and decrease it in the liquid phase, compared to the BBI values used in the new method. Next consider the effect of the solid volume fraction used to combine the dry-solid and liquid concentrations into a wet bulk solids concentration. This solid fraction was estimated from BBI and ESP information (Equation 4.1 in Section 4.1). If the fraction is consistent with that in the BBI's wet bulk solid phase, then the old-method SOF will be higher or lower than the new one depending only on whether the solid or liquid phase dominates. If the old-method solid fraction is an overestimate (as it seems to be in AP-105, for one example) the old-method SOF is somewhat likelier to exceed the new one. If the old-method solid fraction is an underestimate, the opposite is true. As another complication, the old method density for the wet bulk solids may differ from the density given in the BBI. Thus the uncertainty in the estimated solid volume fraction is folded together with differences in solubility and density, and it is very difficult to determine the "real" cause of concentration changes.

The following general rules were used in assessing the causes of changes in the wet bulk solids SOF-3 values (as shown in Tables 4.5 and 4.6):

1. If a comparison of the original ESP output and the BBI showed that both sources showed about the same solubility for an analyte (i.e., its liquid-phase concentration), solubility differences were ruled out as the cause of SOF changes from the old to the new method.

2. If the BBI contained more than one bulk-solids layer and the one used for the tank SOF had distinctly different concentrations for the pertinent analytes, compared to the other solids layers, the SOF changes were considered to be the effect of selecting the maximum-SOF layer. Note that the maximum-SOF layer could have lower concentrations of some analytes than other layers, but higher concentrations of other analytes. Therefore, for layer-selection to be the reason for SOF changes, the layer concentrations had to be different from those in the rest of the tank in the correct direction.

3. When neither layer-selection nor solubility differences explained a change in an analyte concentration, an inaccuracy in the estimated solid volume fraction for the old method was considered to be the cause.

The process of deciding on a cause for concentration changes was only partly quantitative, as can be seen. On the other hand, the variation of analyte concentration from one layer to another in a tank was often so significant that layer-selection was definitely the reason for the concentration change from old to new method. Even considering contributions from solid-fraction error and solubility changes, the use of maximum-SOF layer concentrations appears to have much more effect on wet bulk solids SOFs than any other aspect of the method change.

Partly because of the use of maximum-SOF layers, few tanks showed a significant decrease in SOF under the new method. One exception, AY-102, had a decrease of more than 50\% in SOF-1 and SOF-2 (but only a small decrease in SOF-3). These decreases occurred because the old method's concentrations of wet-bulk-solids $\mathrm{NO}_{2}$ and $\mathrm{OH}$ were based on the average liquid concentration in the tank waste, which was dominated by the relatively high- $\mathrm{NO}_{2}$, high-OH supernatant. The new method uses the measured, very 
low, $\mathrm{NO}_{2}$ concentration in the wet bulk solids, and from this calculates a default $\mathrm{OH}$ concentration that is also very low. The new method probably represents the wet bulk solids layer in AY-102 more accurately than the old, being based on local rather than tank-average concentrations.

The next most common cause of changes in SOF-3 values for wet bulk solids, after maximum-layer choice, was toxicity change in either TOC or lead. Changes in the effective toxicity of calcium and aluminum also appear in the table, but are not primary causes of the SOF-3 change; they consistently account for less than $20 \%$ of the change.

The use of oxalate to represent TOC was the primary cause of the SOF-3 increase in only 2 of 45 tanks, for wet bulk solids, although it was primary in 5 out of 24 tanks for liquids. The choice of oxalate had less effect on wet bulk solids SOFs than on liquids because most of the TOC in solids was already being assigned to oxalate in the old method. The increased toxicity of lead in the solids, which is the primary cause of the SOF-3 increase in 4 tanks, resulted from the choice of lead hydroxide as the solid compound for lead. In the old method, ESP had predicted lead carbonate and lead phosphate, which are less toxic than lead hydroxide, to be the precipitated forms of lead in a number of sludge tanks.

A few of the SOF increases had other causes. In some tanks (e.g., TX-108) the selected maximum-SOF wet bulk solids layer contained little or no aluminum, based on the BBI composition. However, the layer did contain silicon, which in the new method was assigned to the compound $\mathrm{NaAlSiO}_{4}$. (See the discussion in Sections B.2 and B.18 of Appendix B.) Because this compound contains aluminum as well as silicon, the new method in effect "generated" aluminum in greater-than-BBI quantities to match the number of moles of silicon. In many cases (including TX-108) this results in a decreased concentration of aluminum, compared to the old tank-average value that included higher- aluminum layers in the average. In other cases (such as A-101) the aluminum concentration increases from the old-method value. SX-113 was the only tank in which the "generation" of Al contributed to a significant increase in the tank SOF-3, compared to the old method. The increase came about because a layer of Sludge/DE contained a high Si concentration; when the $\mathrm{Si}$ was represented as $\mathrm{NaAlSiO}_{4}$, the resulting $\mathrm{Al}$ concentration exceeded the $\mathrm{BBI}$ value.

In a few cases the inputs to the ESP model, or the model outputs, had been adjusted in some manner in the old method.

- SX-115 and C-111: the composition input had to be modified from that of the tank-average waste to achieve the charge balance that the ESP model requires in its inputs. As a result nitrate was underestimated in the old method. The new method did not require this type of charge balance.

- S-109, B-108, and BY-101: the ESP model could not be made to converge on the BBI-average composition. Convergence was obtained by diluting the waste composition with water. As a result the concentrations and SOFs were underestimated in the old method, contributing (though not as a primary cause) to the increase shown under the new method. Note that this dilution also affected the old-method liquid SOF-3 values in S-109 and BY-101.

- SX-113: The charge balance carried out on ESP outputs in the old method to offset the organic complexant anions (which were added into the composition after ESP modeling) caused hydroxide, nitrate, and nitrite to be zeroed. (See Section 3.3.5 for a complete discussion.) As a result, the SOFs calculated by the old method were underestimated, contributing to an increase in SOF under the new method. 


\subsubsection{Effect on Wet-Bulk-Solid-Phase SOFs of Using Default Hydroxide Concentrations}

The effect of default $\mathrm{OH}$ was tested for the wet bulk solids phase in the same manner as for the liquid phase (Section 4.3.1). In the 2002 BBI there were 31 solids layers for which a comparison could be made, out of a total of 352 solids layers.

Using the default instead of the BBI OH concentration generally did not cause either increases or decreases of more than $10 \%$ in the SOFs. Two tanks (AN-105 and AW-103) showed increases of more than $10 \%$ in a solids layer. Both of these were less than $17 \%$. Four tanks, out of the 20 for which BBI $\mathrm{OH}$ data were available, showed SOF decreases of more than $10 \%$. The maximum decreases seen were $38 \%$ to $56 \%$, which were seen in SX-114 and S-112 solids for all TEELs. It should be noted that the decrease caused by using the default $\mathrm{OH}$ (instead of the BBI value) generally produces closer agreement with the SOF predicted by the old method. To some extent, this outcome is to be expected because the default $\mathrm{OH}$ is consistent with that used in the old-method SOF calculations. Thus, the decrease caused by the default $\mathrm{OH}$ concentration can significantly decrease the new-method SOF, but does not lead to an SOF that is significantly less conservative than the old value. This can be seen from the examples below by comparing the results for the old method to those for the new method with default $\mathrm{OH}$.

$\begin{array}{llll}\text { S-112 } & \text { SOF-1 } & \text { SOF-2 } & \text { SOF-3 } \\ \text { old method SOF } & & & \\ \text { new method SOF, BBI OH } & \text { 3.65E+09 } & 2.72 \mathrm{E}+08 & 1.53 \mathrm{E}+07 \\ \text { new method SOF, default OH } & 1.61 \mathrm{E}+09 & 3.79 \mathrm{E}+08 & 3.30 \mathrm{E}+07 \\ & & & \\ & & & \\ \text { SX-114 } & \text { SOF-1 } & \text { SOF-2 } & \text { SOF-3 } \\ & & & \\ \text { old method SOF } & 1.71 \mathrm{E}+09 & 2.45 \mathrm{E}+08 & 1.46 \mathrm{E}+07 \\ \text { new method SOF, BBI OH } & 3.39 \mathrm{E}+09 & 4.14 \mathrm{E}+08 & 3.31 \mathrm{E}+07 \\ \text { new method SOF, default OH } & 1.53 \mathrm{E}+09 & 2.28 \mathrm{E}+08 & 1.44 \mathrm{E}+07\end{array}$

\subsubsection{Effect of Compound Assignments on Wet-Bulk-Solid-Phase SOFs}

To test for possible nonconservatisms caused by the new method's compound assignments (i.e., changes in the effective toxicity of analytes), the SOF-3 contributions from all analytes and tanks were examined. In seven tanks, decreases in the effective toxicity of $\mathrm{Ca}$ or $\mathrm{Al}$ would have caused decreases of more than $10 \%$ in the SOF-3 had they not been counteracted by conservatisms from other causes. The maximum potential decreases were in tanks T-102 (-40\% change in SOF-3, related to $\mathrm{Al}$ ) and C-204 (-26\% change in SOF-3, caused by Ca). In T-102, the toxicity of Al decreased because in the new method the only $\mathrm{Al}$ present in the maximum-SOF layer came from the $\mathrm{NaAlSiO}_{4}$ that was used to represent $\mathrm{Si}$ (see Section B.18), whereas the old method used the tank-average composition with its high Al concentration that was represented primarily as $\mathrm{Al}(\mathrm{OH})_{3}$. As can be seen in Table B.2, at the TEEL-3 level $\mathrm{NaAlSiO}_{4}$ is less than half as toxic as $\mathrm{Al}(\mathrm{OH})_{3}$. In C-204, the toxicity of Ca decreased because Ca was represented as $\mathrm{Ca}_{5} \mathrm{OH}\left(\mathrm{PO}_{4}\right)_{3}$ by the new method (Section B.4), whereas the ESP model predicted $\mathrm{CaCO}_{3}$ and a small amount of $\mathrm{CaF}_{2}$ in the old method. Note that the relative toxicities of $\mathrm{Al}$ compounds, and of $\mathrm{Ca}$ 
compounds, make the TEEL-3 level the one where toxicity decreases are most marked; therefore the SOF-3 is the best standard of comparison for these toxicity effects.

In six of the seven tanks where potential SOF-3 decreases of more than $10 \%$ were found, the new-method SOF-3 was greater than the old. This outcome indicates that the decrease in effective toxicity of one analyte was offset by other conservatisms: for example, increases in the concentrations or toxicities of other analytes, or the choice of the maximum-SOF layer. In the seventh tank, AX-104, a decrease in Ca toxicity had a potential effect of decreasing the SOF-3 by 12\%, and the new-method SOF-3 was less than the old-method SOF-3 by $11 \%$. Although the Ca toxicity was the chief cause of this decrease in SOF, the effect was not major; it falls within the uncertainty of the BBI composition. 
Table 4.3. Causes of Method-Related Liquid-Phase SOF-3 Decreases of More Than 30\%

\begin{tabular}{|c|c|c|c|c|c|c|c|c|c|}
\hline Tank & $\begin{array}{c}\text { New/Old } \\
\text { SOF-3 } \\
\text { Ratio }\end{array}$ & $\begin{array}{c}\text { New SOF- } \\
3\end{array}$ & $\begin{array}{c}\text { Old SOF- } \\
3\end{array}$ & Analyte & $\begin{array}{c}\text { New/Old } \\
\text { Contrib-3 } \\
\text { Ratio }\end{array}$ & $\begin{array}{c}\text { New/Old } \\
\text { Conc. } \\
\text { Ratio }\end{array}$ & $\begin{array}{c}\text { New/Old } \\
\text { Effective } \\
\text { TEEL-3 } \\
\text { Ratio }\end{array}$ & $\begin{array}{c}\text { Fraction of } \\
\text { SOF decrease } \\
\text { from this } \\
\text { analyte }\end{array}$ & Comments \\
\hline \multirow{2}{*}{ B-111 } & \multirow{2}{*}{0.059} & \multirow{2}{*}{$2.0 \mathrm{E}+05$} & \multirow{2}{*}{$3.4 \mathrm{E}+06$} & $\mathrm{NO}_{3}$ & 0.087 & 0.087 & 1.00 & $44 \%$ & \multirow{2}{*}{$\begin{array}{l}\text { Difference between ESP and BBI solubility. } \\
\text { BBI used estimate for liquid. }\end{array}$} \\
\hline & & & & $\mathrm{NO}_{2}$ & 0.018 & 0.018 & 1.00 & $48 \%$ & \\
\hline B-110 & 0.060 & $3.3 \mathrm{E}+05$ & $5.4 \mathrm{E}+06$ & $\mathrm{NO}_{3}$ & 0.030 & 0.030 & 1.00 & $86 \%$ & $\begin{array}{l}\text { Difference between ESP and BBI solubility. } \\
\text { BBI used estimates for liquid and solid. }\end{array}$ \\
\hline \multirow{4}{*}{$\mathrm{T}-110$} & \multirow{4}{*}{0.34} & \multirow{4}{*}{$4.7 \mathrm{E}+05$} & \multirow{4}{*}{$1.4 \mathrm{E}+06$} & TOC & 0.046 & 0.044 & 0.96 & $11 \%$ & \multirow{2}{*}{$\begin{array}{l}\text { Difference between ESP and BBI solubility. } \\
\text { BBI was measured. }\end{array}$} \\
\hline & & & & $\mathrm{U}$ & 0.049 & 0.048 & 0.99 & $12 \%$ & \\
\hline & & & & $\mathrm{NO}_{2}$ & 0.010 & 0.010 & 1.00 & $16 \%$ & Difference between ESP and BBI solubility. \\
\hline & & & & $\mathrm{NO}_{3}$ & 0.29 & 0.29 & 1.00 & $67 \%$ & \\
\hline C-110 & 0.37 & $1.1 \mathrm{E}+06$ & $3.1 \mathrm{E}+06$ & $\mathrm{NO}_{3}$ & 0.33 & 0.33 & 1.00 & $87 \%$ & $\begin{array}{l}\text { Difference between ESP and BBI solubility. } \\
\text { BBI was measured. }\end{array}$ \\
\hline \multirow{2}{*}{ TX-117 } & \multirow{2}{*}{0.48} & \multirow{2}{*}{$3.2 \mathrm{E}+06$} & \multirow{2}{*}{$6.6 \mathrm{E}+06$} & $\mathrm{NO}_{2}$ & 0.29 & 0.29 & 1.00 & $33 \%$ & \multirow{2}{*}{$\begin{array}{l}\text { Difference between ESP and BBI solubility. } \\
\text { BBI used estimates for liquid and solid. }\end{array}$} \\
\hline & & & & $\mathrm{NO}_{3}$ & 0.58 & 0.58 & 1.00 & $51 \%$ & \\
\hline \multirow{3}{*}{ TY-104 } & \multirow{3}{*}{0.51} & \multirow{3}{*}{$2.2 \mathrm{E}+06$} & \multirow{3}{*}{$4.4 \mathrm{E}+06$} & $\mathrm{NO}_{3}$ & 4.5 & 4.5 & 1.00 & $-48 \%$ & \multirow{3}{*}{$\begin{array}{l}\text { Difference between ESP and BBI solubility } \\
\text { BBI used estimates for liquid and solid. }\end{array}$} \\
\hline & & & & $\mathrm{NO}_{2}$ & 0.15 & 0.15 & 1.00 & $74 \%$ & \\
\hline & & & & $\mathrm{U}$ & 0.0021 & 0.0019 & 0.93 & $80 \%$ & \\
\hline \multirow{2}{*}{ TY-101 } & \multirow{2}{*}{0.51} & \multirow{2}{*}{$3.2 \mathrm{E}+06$} & \multirow{2}{*}{$6.2 \mathrm{E}+06$} & $\mathrm{NO}_{2}$ & 0.53 & 0.54 & 1.00 & $13 \%$ & \multirow{2}{*}{$\begin{array}{l}\text { Difference between ESP and BBI solubility. } \\
\text { BBI used estimates for liquid and solid. }\end{array}$} \\
\hline & & & & $\mathrm{NO}_{3}$ & 0.45 & 0.45 & 1.00 & $93 \%$ & \\
\hline \multirow{3}{*}{ B-104 } & \multirow{3}{*}{0.52} & \multirow{3}{*}{$3.2 E+06$} & \multirow{3}{*}{$6.1 \mathrm{E}+06$} & $\mathrm{NO}_{2}$ & 3.9 & 3.9 & 1.00 & $-11 \%$ & \multirow{3}{*}{$\begin{array}{l}\text { Difference between ESP and BBI solubility. } \\
\text { BBI used estimate for liquid. }\end{array}$} \\
\hline & & & & $\mathrm{U}$ & 0.019 & 0.019 & 0.99 & $12 \%$ & \\
\hline & & & & $\mathrm{NO}_{3}$ & 0.46 & 0.46 & 1.00 & $97 \%$ & \\
\hline
\end{tabular}


Table 4.3. (contd.)

\begin{tabular}{|c|c|c|c|c|c|c|c|c|c|}
\hline Tank & $\begin{array}{l}\text { New/Old } \\
\text { SOF-3 } \\
\text { Ratio } \\
\end{array}$ & $\begin{array}{c}\text { New SOF- } \\
3 \\
\end{array}$ & \begin{tabular}{|c|} 
Old SOF- \\
3 \\
\end{tabular} & Analyte & $\begin{array}{l}\text { New/Old } \\
\text { Contrib-3 } \\
\text { Ratio }\end{array}$ & $\begin{array}{l}\text { New/Old } \\
\text { Conc. } \\
\text { Ratio }\end{array}$ & $\begin{array}{c}\text { New/Old } \\
\text { Effective } \\
\text { TEEL-3 } \\
\text { Ratio } \\
\end{array}$ & $\begin{array}{l}\text { Fraction of } \\
\text { SOF decrease } \\
\text { from this } \\
\text { analyte }\end{array}$ & Comments \\
\hline \multirow{3}{*}{ AN-106 } & \multirow{3}{*}{0.55} & \multirow{3}{*}{$2.5 \mathrm{E}+06$} & \multirow{3}{*}{$4.5 \mathrm{E}+06$} & TOC & 8.9 & 1.2 & 0.13 & $-10 \%$ & $\begin{array}{l}\text { Increase is the result of toxicity change (by } \\
\text { assigning oxalate), not concentration change }\end{array}$ \\
\hline & & & & $\mathrm{NO}_{3}$ & 0.58 & 0.60 & 1.03 & $35 \%$ & \multirow{2}{*}{$\begin{array}{l}\text { Difference between ESP and BBI solubility. } \\
\text { BBI used estimate for solids. }\end{array}$} \\
\hline & & & & $\mathrm{NO}_{2}$ & 0.30 & 0.31 & 1.04 & $70 \%$ & \\
\hline \multirow{3}{*}{ B-204 } & \multirow{3}{*}{0.59} & \multirow{3}{*}{$6.6 \mathrm{E}+05$} & \multirow{3}{*}{$1.1 \mathrm{E}+06$} & TOC & 1.35E-05 & 8.51E-06 & 0.63 & $12 \%$ & $\begin{array}{l}\text { Difference between ESP and BBI solubility. } \\
\text { BBI used estimates for liquid and solid. } \\
\end{array}$ \\
\hline & & & & $\mathrm{F}$ & 0.62 & 0.63 & 1.02 & $17 \%$ & \multirow{2}{*}{$\begin{array}{l}\text { Difference between ESP and BBI solubility. } \\
\text { BBI was measured. }\end{array}$} \\
\hline & & & & $\mathrm{NO}_{3}$ & 0.58 & 0.58 & 0.99 & $68 \%$ & \\
\hline \multirow{2}{*}{ B-102 } & \multirow{2}{*}{0.60} & \multirow{2}{*}{$3.4 \mathrm{E}+06$} & \multirow{2}{*}{$5.7 \mathrm{E}+06$} & $\mathrm{NO}_{2}$ & 0.56 & 0.56 & 1.00 & $16 \%$ & \multirow{2}{*}{$\begin{array}{l}\text { Difference between ESP and BBI solubility. } \\
\text { BBI used estimates for liquid and solid. }\end{array}$} \\
\hline & & & & $\mathrm{NO}_{3}$ & 0.58 & 0.58 & 1.00 & $76 \%$ & \\
\hline B-106 & 0.62 & $3.2 \mathrm{E}+06$ & $5.1 \mathrm{E}+06$ & $\mathrm{NO}_{3}$ & 0.53 & 0.53 & 1.00 & $112 \%$ & $\begin{array}{l}\text { Difference between ESP and BBI solubility. } \\
\text { BBI used estimate for liquid. }\end{array}$ \\
\hline \multirow{2}{*}{ B-103 } & \multirow{2}{*}{0.64} & \multirow{2}{*}{$3.5 \mathrm{E}+06$} & \multirow{2}{*}{$5.6 \mathrm{E}+06$} & $\mathrm{NO}_{2}$ & 0.50 & 0.50 & 1.00 & $23 \%$ & \multirow{2}{*}{$\begin{array}{l}\text { Difference between ESP and BBI solubility. } \\
\text { BBI used estimates for liquid and solid. }\end{array}$} \\
\hline & & & & $\mathrm{NO}_{3}$ & 0.65 & 0.64 & 1.00 & $64 \%$ & \\
\hline \multirow{3}{*}{ T-108 } & \multirow{3}{*}{0.65} & \multirow{3}{*}{$3.6 \mathrm{E}+06$} & \multirow{3}{*}{$5.5 \mathrm{E}+06$} & $\mathrm{CO}_{3}$ & 0.13 & 0.13 & 1.00 & $15 \%$ & \multirow{3}{*}{$\begin{array}{l}\text { Difference between ESP and BBI solubility. } \\
\text { BBI used estimate for liquid. }\end{array}$} \\
\hline & & & & $\mathrm{NO}_{2}$ & 0.54 & 0.54 & 1.00 & $20 \%$ & \\
\hline & & & & $\mathrm{NO}_{3}$ & 0.66 & 0.66 & 1.00 & $64 \%$ & \\
\hline
\end{tabular}


Table 4.4. Causes of Method-Related Liquid-Phase SOF-3 Increases of More Than 30\%

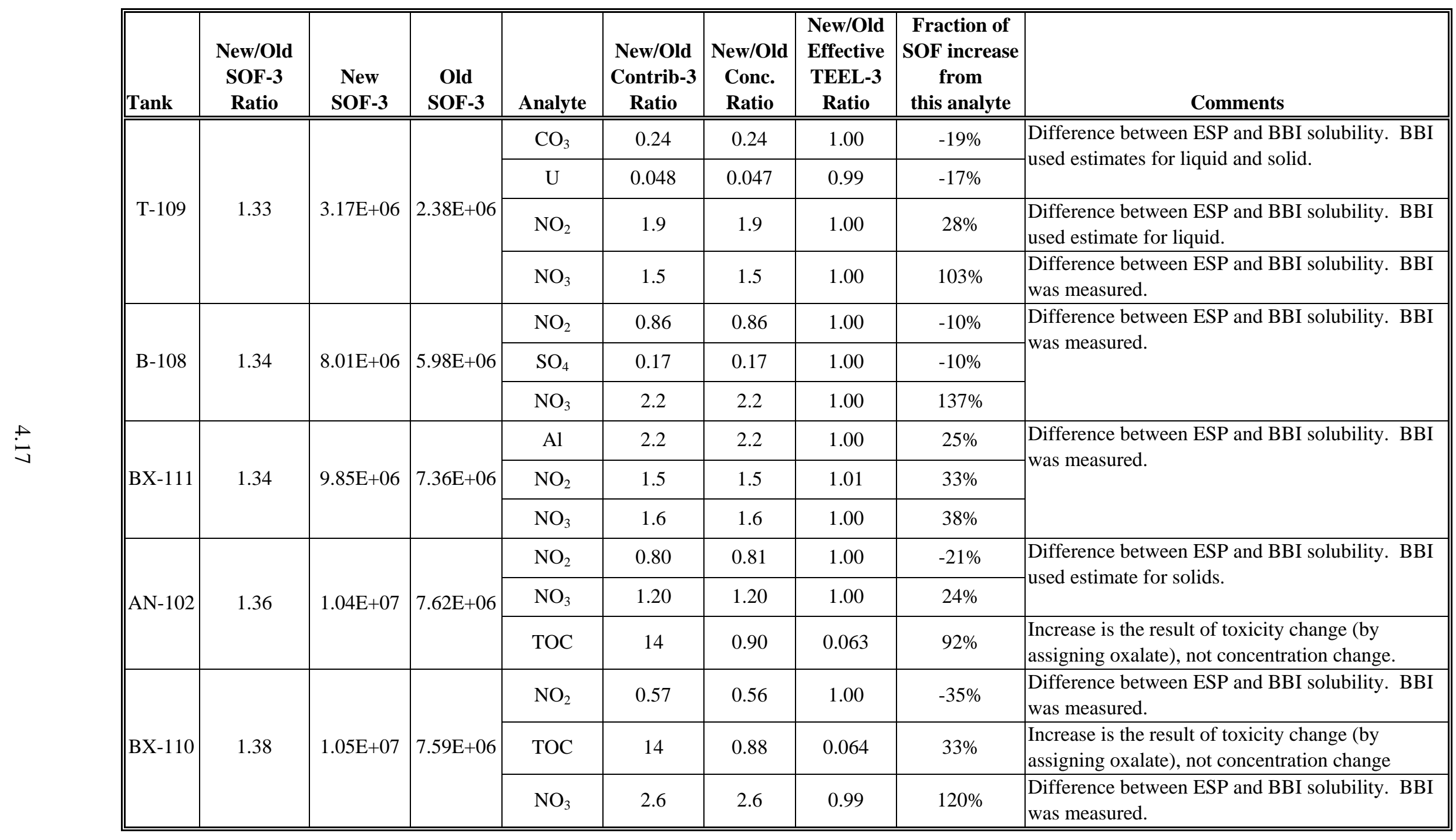


Table 4.4. (contd.)

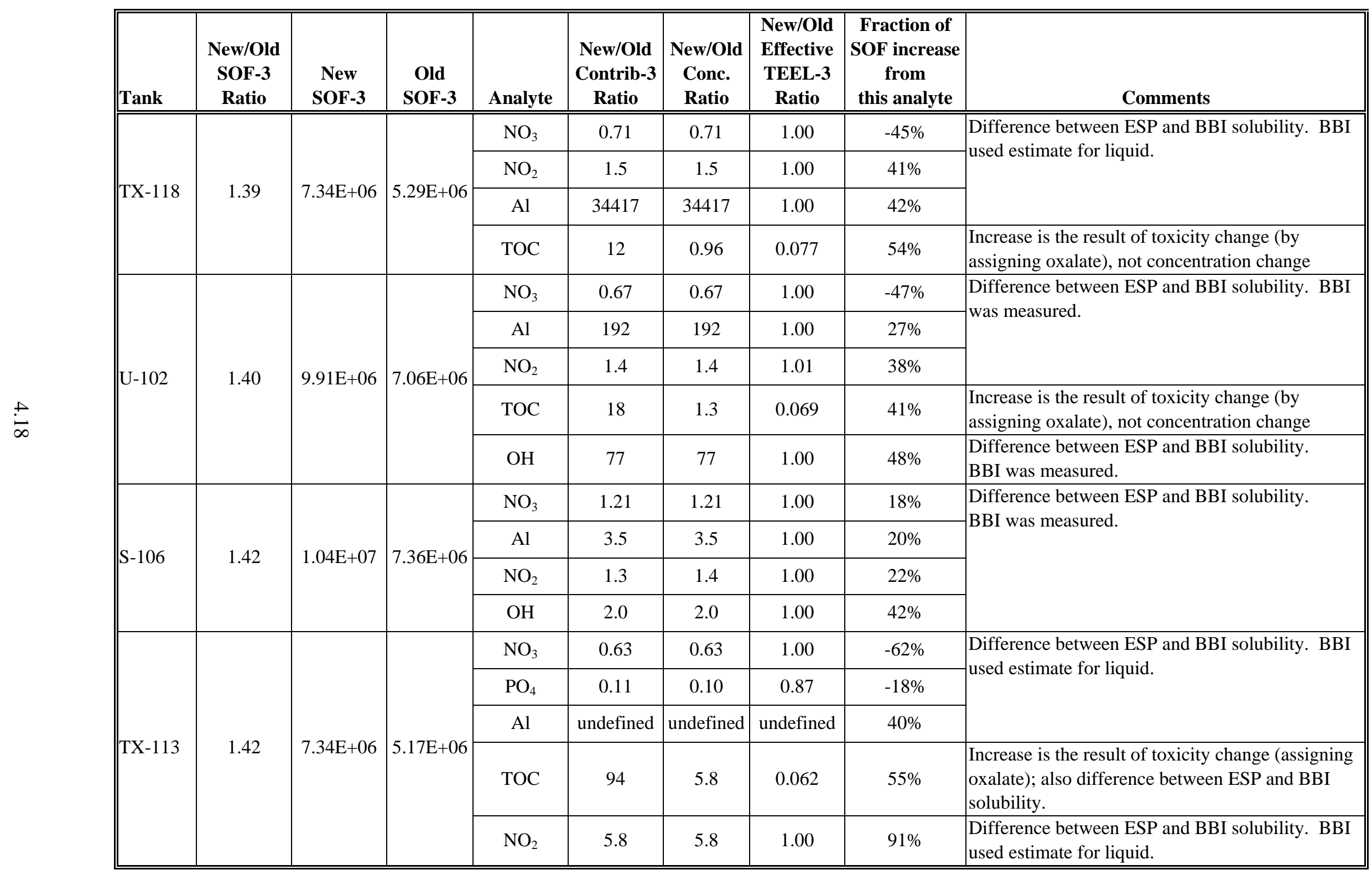


Table 4.4. (contd.)

\begin{tabular}{|c|c|c|c|c|c|c|c|c|c|}
\hline \multirow{11}{*}{ AW-104 } & \begin{tabular}{|c|} 
New/Old \\
SOF-3 \\
Ratio
\end{tabular} & $\begin{array}{c}\text { New } \\
\text { SOF-3 } \\
\end{array}$ & $\begin{array}{c}\text { Old } \\
\text { SOF-3 } \\
\end{array}$ & Analyte & $\begin{array}{c}\text { New/Old } \\
\text { Contrib-3 } \\
\text { Ratio } \\
\end{array}$ & $\begin{array}{l}\text { New/Old } \\
\text { Conc. } \\
\text { Ratio } \\
\end{array}$ & $\begin{array}{c}\text { New/Old } \\
\text { Effective } \\
\text { TEEL-3 } \\
\text { Ratio } \\
\end{array}$ & \begin{tabular}{|c|} 
Fraction of \\
SOF increase \\
from \\
this analyte \\
\end{tabular} & Comments \\
\hline & \multirow{5}{*}{1.50} & \multirow{5}{*}{$9.73 \mathrm{E}+06$} & \multirow{5}{*}{$6.50 \mathrm{E}+06$} & $\mathrm{NO}_{3}$ & 0.77 & 0.77 & 1.00 & $-16 \%$ & \multirow{5}{*}{$\begin{array}{l}\text { Difference between ESP and BBI solubility. BBI } \\
\text { was measured; ESP was diluted for convergence. }\end{array}$} \\
\hline & & & & $\mathrm{Cr}(\mathrm{VI})$ & 4.3 & 4.3 & 1.00 & $17 \%$ & \\
\hline & & & & $\mathrm{Al}$ & 2.6 & 2.6 & 1.00 & $20 \%$ & \\
\hline & & & & $\mathrm{OH}$ & 1.3 & 1.3 & 1.00 & $29 \%$ & \\
\hline & & & & $\mathrm{NO}_{2}$ & 4.4 & 4.4 & 1.00 & $50 \%$ & \\
\hline & \multirow{5}{*}{1.50} & \multirow{5}{*}{$7.95 \mathrm{E}+06$} & \multirow{5}{*}{$5.28 \mathrm{E}+06$} & TOC & 8.2 & 0.58 & 0.071 & $13 \%$ & $\begin{array}{l}\text { Increase is the result of toxicity change (assigning } \\
\text { oxalate); there is also a difference between ESP } \\
\text { and BBI solubility. BBI was measured. }\end{array}$ \\
\hline & & & & $\mathrm{OH}$ & 1.2 & 1.2 & 1.00 & $14 \%$ & \multirow[t]{4}{*}{ Use of concentration from maximum-SOF layer. } \\
\hline & & & & $\mathrm{Al}$ & 2.9 & 2.9 & 1.00 & $17 \%$ & \\
\hline & & & & $\mathrm{NO}_{3}$ & 1.6 & 1.6 & 1.01 & $27 \%$ & \\
\hline & & & & $\mathrm{NO}_{2}$ & 1.6 & 1.6 & 1.01 & $33 \%$ & \\
\hline & \multirow{4}{*}{1.51} & \multirow{4}{*}{$1.07 \mathrm{E}+07$} & \multirow{4}{*}{$7.11 \mathrm{E}+06$} & $\mathrm{Al}$ & 1.8 & 1.8 & 1.00 & $12 \%$ & \multirow{2}{*}{$\begin{array}{l}\text { Difference between ESP and BBI solubility. BBI } \\
\text { was measured; ESP was diluted for convergence. }\end{array}$} \\
\hline & & & & $\mathrm{NO}_{3}$ & 1.3 & 1.3 & 0.99 & $14 \%$ & \\
\hline BY-101 & & & & TOC & 31 & 2.0 & 0.065 & $28 \%$ & $\begin{array}{l}\text { Increase is the result of toxicity change (assigning } \\
\text { oxalate) and concentration change }\end{array}$ \\
\hline & & & & $\mathrm{NO}_{2}$ & 2.1 & 2.1 & 0.99 & $36 \%$ & $\begin{array}{l}\text { Difference between ESP and BBI solubility. BBI } \\
\text { was measured; ESP was diluted for convergence. }\end{array}$ \\
\hline & \multirow{5}{*}{1.56} & \multirow{5}{*}{$2.09 \mathrm{E}+06$} & \multirow{5}{*}{$1.33 \mathrm{E}+06$} & TOC & 0.00027 & 0.000088 & 0.32 & $-14 \%$ & \multirow[t]{5}{*}{ Use of concentration from maximum-SOF layer. } \\
\hline & & & & $\mathrm{Al}$ & 6.9 & 6.9 & 1.00 & $11 \%$ & \\
\hline AW-105 & & & & $\mathrm{OH}$ & 1.6 & 1.5 & 0.98 & $20 \%$ & \\
\hline & & & & $\mathrm{NO}_{3}$ & 1.5 & 1.5 & 0.98 & $31 \%$ & \\
\hline & & & & $\mathrm{NO}_{2}$ & 2.7 & 2.7 & 0.98 & $45 \%$ & \\
\hline
\end{tabular}


Table 4.4. (contd.)

\begin{tabular}{|c|c|c|c|c|c|c|c|c|c|}
\hline ||Tank & $\begin{array}{l}\text { New/Old } \\
\text { SOF-3 } \\
\text { Ratio }\end{array}$ & $\begin{array}{l}\text { New } \\
\text { SOF-3 }\end{array}$ & $\begin{array}{l}\text { Old } \\
\text { SOF-3 }\end{array}$ & Analyte & $\begin{array}{l}\text { New/Old } \\
\text { Contrib-3 } \\
\text { Ratio }\end{array}$ & $\begin{array}{c}\text { New/Old } \\
\text { Conc. } \\
\text { Ratio }\end{array}$ & $\begin{array}{c}\text { New/Old } \\
\text { Effective } \\
\text { TEEL-3 } \\
\text { Ratio }\end{array}$ & \begin{tabular}{|c|} 
Fraction of \\
SOF increase \\
from \\
this analyte
\end{tabular} & Comments \\
\hline \multirow{3}{*}{ S-107 } & \multirow{3}{*}{1.61} & \multirow{3}{*}{$5.39 \mathrm{E}+06$} & \multirow{3}{*}{$3.35 \mathrm{E}+06$} & $\mathrm{NO}_{3}$ & 1.3 & 1.3 & 1.00 & $18 \%$ & \multirow{3}{*}{$\begin{array}{l}\text { Difference between ESP and BBI solubility. BBI } \\
\text { was measured. }\end{array}$} \\
\hline & & & & $\mathrm{NO}_{2}$ & 1.5 & 1.5 & 1.00 & $30 \%$ & \\
\hline & & & & $\mathrm{OH}$ & 2.6 & 2.6 & 1.00 & $42 \%$ & \\
\hline \multirow{3}{*}{ B-107 } & \multirow{3}{*}{1.69} & \multirow{3}{*}{$4.97 \mathrm{E}+06$} & \multirow{3}{*}{$2.94 \mathrm{E}+06$} & $\mathrm{~F}$ & 0.024 & 0.024 & 1.00 & $-45 \%$ & \multirow{3}{*}{$\begin{array}{l}\text { Difference between ESP and BBI solubility. BBI } \\
\text { was measured. }\end{array}$} \\
\hline & & & & $\mathrm{SO}_{4}$ & 0.16 & 0.16 & 1.00 & $-21 \%$ & \\
\hline & & & & $\mathrm{NO}_{3}$ & 3.5 & 3.5 & 1.00 & $159 \%$ & \\
\hline AN-107 & 1.74 & $9.95 E+06$ & $5.71 \mathrm{E}+06$ & TOC & 15 & 0.91 & 0.062 & $100 \%$ & $\begin{array}{l}\text { Increase is the result of toxicity change (by } \\
\text { assigning oxalate), not concentration change }\end{array}$ \\
\hline U-106 & 1.76 & $1.15 \mathrm{E}+07$ & $6.50 \mathrm{E}+06$ & TOC & 18 & 1.1 & 0.063 & $90 \%$ & $\begin{array}{l}\text { Increase is the result of toxicity change (by } \\
\text { assigning oxalate), not concentration change }\end{array}$ \\
\hline \multirow{3}{*}{ C-103 } & \multirow{3}{*}{1.88} & \multirow{3}{*}{$1.96 \mathrm{E}+06$} & \multirow{3}{*}{$1.04 \mathrm{E}+06$} & $\mathrm{NO}_{2}$ & 0.73 & 0.72 & 0.98 & $-17 \%$ & $\begin{array}{l}\text { Difference between ESP and BBI solubility. BBI } \\
\text { was measured. }\end{array}$ \\
\hline & & & & U & 44 & 40 & 0.92 & $55 \%$ & $\begin{array}{l}\text { Difference between ESP and BBI solubility. BBI } \\
\text { liquid was measured but solids were estimate. }\end{array}$ \\
\hline & & & & TOC & 3.2 & 0.40 & 0.13 & $56 \%$ & $\begin{array}{l}\text { Increase is the result of toxicity change (assigning } \\
\text { oxalate); also difference between ESP and BBI } \\
\text { solubility. BBI was measured. }\end{array}$ \\
\hline \multirow{3}{*}{ U-202 } & \multirow{3}{*}{1.95} & \multirow{3}{*}{$4.62 E+06$} & \multirow{3}{*}{$2.37 \mathrm{E}+06$} & $\mathrm{NO}_{3}$ & 1.5 & 1.5 & 1.00 & $14 \%$ & \multirow[t]{3}{*}{$\begin{array}{l}\text { Difference between ESP and BBI solubility. BBI } \\
\text { used estimates for liquid and solids. }\end{array}$} \\
\hline & & & & $\mathrm{Al}$ & 16 & 16 & 1.00 & $36 \%$ & \\
\hline & & & & $\mathrm{NO}_{2}$ & 2.4 & 2.4 & 1.00 & $51 \%$ & \\
\hline \multirow{3}{*}{ T-103 } & \multirow{3}{*}{1.96} & \multirow{3}{*}{$3.09 \mathrm{E}+06$} & \multirow{3}{*}{$1.58 \mathrm{E}+06$} & $\mathrm{Al}$ & 944 & 944 & 1.00 & $19 \%$ & $\begin{array}{l}\text { Difference between ESP and BBI solubility. BBI } \\
\text { used estimates for liquid and solids. }\end{array}$ \\
\hline & & & & $\mathrm{NO}_{3}$ & 1.9 & 1.9 & 1.00 & $37 \%$ & \multirow{2}{*}{$\begin{array}{l}\text { Use of concentration from maximum-SOF layer. } \\
\text { BBI used estimates for liquid and solids. }\end{array}$} \\
\hline & & & & $\mathrm{NO}_{2}$ & 2.2 & 2.2 & 1.00 & $45 \%$ & \\
\hline
\end{tabular}


Table 4.4. (contd.)

\begin{tabular}{|c|c|c|c|c|c|c|c|c|c|}
\hline Tank & $\begin{array}{l}\text { New/Old } \\
\text { SOF-3 } \\
\text { Ratio }\end{array}$ & $\begin{array}{l}\text { New } \\
\text { SOF-3 }\end{array}$ & $\begin{array}{c}\text { Old } \\
\text { SOF-3 }\end{array}$ & Analyte & \begin{tabular}{|c|} 
New/Old \\
Contrib-3 \\
Ratio
\end{tabular} & $\begin{array}{l}\text { New/Old } \\
\text { Conc. } \\
\text { Ratio } \\
\end{array}$ & $\begin{array}{c}\text { New/Old } \\
\text { Effective } \\
\text { TEEL-3 } \\
\text { Ratio } \\
\end{array}$ & \begin{tabular}{|c} 
Fraction of \\
SOF increase \\
from \\
this analyte
\end{tabular} & Comments \\
\hline \multirow{3}{*}{ BX-105 } & \multirow{3}{*}{2.00} & \multirow{3}{*}{$4.95 \mathrm{E}+06$} & \multirow{3}{*}{$2.48 \mathrm{E}+06$} & $\mathrm{NO}_{3}$ & 1.7 & 1.7 & 1.00 & $26 \%$ & $\begin{array}{l}\text { Difference between ESP and BBI solubility. BBI } \\
\text { used estimates for liquid and solids. }\end{array}$ \\
\hline & & & & TOC & 39 & 2.4 & 0.062 & $41 \%$ & $\begin{array}{l}\text { Increase is the result of toxicity change (assigning } \\
\text { oxalate) and difference between ESP and BBI } \\
\text { solubility. }\end{array}$ \\
\hline & & & & $\mathrm{NO}_{2}$ & 2.2 & 2.2 & 1.00 & $43 \%$ & $\begin{array}{l}\text { Difference between ESP and BBI solubility. BBI } \\
\text { used estimates for liquid and solids. }\end{array}$ \\
\hline \multirow{3}{*}{ U-201 } & \multirow{3}{*}{2.04} & \multirow{3}{*}{$4.99 \mathrm{E}+06$} & \multirow{3}{*}{$2.44 \mathrm{E}+06$} & $\mathrm{NO}_{3}$ & 1.6 & 1.6 & 1.00 & $15 \%$ & \multirow{3}{*}{$\begin{array}{l}\text { Difference between ESP and BBI solubility. BB } \\
\text { used estimates for liquid and solids. }\end{array}$} \\
\hline & & & & $\mathrm{Al}$ & 17 & 17 & 1.00 & $35 \%$ & \\
\hline & & & & $\mathrm{NO}_{2}$ & 2.5 & 2.5 & 1.00 & $51 \%$ & \\
\hline \multirow{3}{*}{ C-106 } & \multirow{3}{*}{2.20} & \multirow{3}{*}{$1.16 \mathrm{E}+06$} & \multirow{3}{*}{$5.26 \mathrm{E}+05$} & U & 8.7 & 8.0 & 0.92 & $12 \%$ & $\begin{array}{l}\text { Difference between ESP and BBI solubility. BBI } \\
\text { was measured. }\end{array}$ \\
\hline & & & & TOC & 3.5 & 1.1 & 0.32 & $39 \%$ & $\begin{array}{l}\text { Increase is the result of toxicity change (by } \\
\text { assigning oxalate), not concentration change }\end{array}$ \\
\hline & & & & $\mathrm{NO}_{2}$ & 7.5 & 7.5 & 1.00 & $43 \%$ & $\begin{array}{l}\text { Difference between ESP and BBI solubility. BBI } \\
\text { was measured. }\end{array}$ \\
\hline \multirow{3}{*}{ U-203 } & \multirow{3}{*}{2.42} & \multirow{3}{*}{$4.96 \mathrm{E}+06$} & \multirow{3}{*}{$2.05 E+06$} & $\mathrm{NO}_{3}$ & 2.0 & 2.0 & 1.00 & $17 \%$ & \multirow[t]{3}{*}{$\begin{array}{l}\text { Difference between ESP and BBI solubility. BBI } \\
\text { used estimates for liquid and solids. }\end{array}$} \\
\hline & & & & $\mathrm{Al}$ & 22 & 22 & 1.00 & $32 \%$ & \\
\hline & & & & $\mathrm{NO}_{2}$ & 3.0 & 3.0 & 1.00 & $50 \%$ & \\
\hline
\end{tabular}


Table 4.5. Causes of Method-Related Wet Bulk Solids SOF-3 Decreases of More Than 30\%

\begin{tabular}{|c|c|c|c|c|c|c|c|c|c|}
\hline Tank & \begin{tabular}{|c|} 
New/Old \\
SOF-3 \\
Ratio \\
\end{tabular} & $\begin{array}{c}\text { New } \\
\text { SOF-3 }\end{array}$ & $\begin{array}{c}\text { Old } \\
\text { SOF-3 } \\
\end{array}$ & Analyte & $\begin{array}{c}\text { New/Old } \\
\text { Contrib-3 } \\
\text { Ratio } \\
\end{array}$ & $\begin{array}{l}\text { New/Old } \\
\text { Conc. } \\
\text { Ratio } \\
\end{array}$ & $\begin{array}{l}\text { New/Old } \\
\text { Effective } \\
\text { TEEL-3 } \\
\text { Ratio }\end{array}$ & $\begin{array}{l}\text { Fraction of } \\
\text { SOF decrease } \\
\text { from this } \\
\text { analyte }\end{array}$ & Comments \\
\hline \multirow{5}{*}{ AP-105 } & \multirow{5}{*}{0.55} & \multirow{5}{*}{$7.14 \mathrm{E}+06$} & \multirow{5}{*}{$1.31 \mathrm{E}+07$} & $\mathrm{NO}_{2}$ & undefined & undefined & undefined & $-20 \%$ & \multirow{5}{*}{$\begin{array}{l}\text { Artifact of using an estimated solid fraction } \\
\text { (1.0) to convert old method from dry-solids } \\
\text { basis to bulk wet solids. For } \mathrm{Al}, \mathrm{CO}_{3} \text {, and } \mathrm{F} \\
\text { there was also a difference in the ESP and } \\
\text { BBI solubilities; the BBI used an estimate } \\
\text { for the liquid. }\end{array}$} \\
\hline & & & & TOC & 4.4 & 4.4 & 1.00 & $-13 \%$ & \\
\hline & & & & $\mathrm{F}$ & 0.52 & 0.52 & 1.00 & $15 \%$ & \\
\hline & & & & $\mathrm{CO}_{3}$ & 0.25 & 0.25 & 1.00 & $21 \%$ & \\
\hline & & & & $\mathrm{Al}$ & 0.055 & 0.056 & 1.02 & $89 \%$ & \\
\hline AW-102 & 0.56 & $1.11 \mathrm{E}+07$ & $1.99 \mathrm{E}+07$ & $\mathrm{Al}$ & 0.36 & 0.38 & 1.06 & $93 \%$ & $\begin{array}{l}\text { Artifact of using an estimated solid fraction } \\
(0.93) \text { to convert old method from dry- } \\
\text { solids basis to bulk wet solids; also a } \\
\text { difference in ESP and BBI solubilities. The } \\
\text { BBI used an estimate for liquid and solids. }\end{array}$ \\
\hline C-203 & 0.59 & $1.63 E+08$ & $2.78 \mathrm{E}+08$ & $\mathrm{~Pb}$ & 0.58 & 0.58 & 1.00 & $94 \%$ & $\begin{array}{l}\text { Artifact of using an estimated solid fraction } \\
(0.38) \text { to convert old method from dry- } \\
\text { solids basis to bulk wet solids. }\end{array}$ \\
\hline C-201 & 0.61 & $2.05 E+08$ & $3.34 \mathrm{E}+08$ & $\mathrm{~Pb}$ & 0.61 & 0.61 & 1.00 & $93 \%$ & $\begin{array}{l}\text { Artifact of using an estimated solid fraction } \\
\text { (0.56) to convert old method from dry- } \\
\text { solids basis to bulk wet solids. }\end{array}$ \\
\hline \multirow{5}{*}{ AN-102 } & \multirow{5}{*}{0.65} & \multirow{5}{*}{$1.24 \mathrm{E}+07$} & \multirow{5}{*}{$1.90 \mathrm{E}+07$} & $\mathrm{NO}_{2}$ & 4.3 & 4.3 & 1.00 & $-28 \%$ & \multirow{5}{*}{$\begin{array}{l}\text { Artifact of using an estimated solid fraction } \\
\text { (0.81) to convert old method from dry- } \\
\text { solids basis to bulk wet solids. For TOC } \\
\text { there was also a toxicity change (by } \\
\text { assigning oxalate). }\end{array}$} \\
\hline & & & & TOC & 1.3 & 1.1 & 0.85 & $-14 \%$ & \\
\hline & & & & $\mathrm{Pb}$ & 0.082 & 0.082 & 1.00 & $17 \%$ & \\
\hline & & & & $\mathrm{Al}$ & 0.17 & 0.18 & 1.06 & $31 \%$ & \\
\hline & & & & $\mathrm{NO}_{3}$ & 0.39 & 0.40 & 1.01 & $85 \%$ & \\
\hline
\end{tabular}


Table 4.6. Causes of Method-Related Wet Bulk Solids SOF-3 Increases of More Than $30 \%$

\begin{tabular}{|c|c|c|c|c|c|c|c|c|c|}
\hline Tank & $\begin{array}{c}\text { New/Old } \\
\text { SOF-3 } \\
\text { Ratio } \\
\end{array}$ & $\begin{array}{l}\text { New } \\
\text { SOF-3 }\end{array}$ & $\begin{array}{c}\text { Old } \\
\text { SOF-3 }\end{array}$ & Analyte & $\begin{array}{c}\text { New/Old } \\
\text { Contrib-3 } \\
\text { Ratio }\end{array}$ & $\begin{array}{c}\text { New/Old } \\
\text { Conc. } \\
\text { Ratio } \\
\end{array}$ & $\begin{array}{l}\text { New/Old } \\
\text { Effective } \\
\text { TEEL-3 } \\
\text { Ratio } \\
\end{array}$ & $\begin{array}{c}\text { Fraction of } \\
\text { SOF increase } \\
\text { from this } \\
\text { analyte }\end{array}$ & Comments \\
\hline U-106 & 1.31 & $1.21 \mathrm{E}+07$ & $9.22 \mathrm{E}+06$ & TOC & 5.4 & 0.89 & 0.17 & $109 \%$ & $\begin{array}{l}\text { Increase is the result of toxicity change (by } \\
\text { assigning oxalate), not concentration change }\end{array}$ \\
\hline \multirow[t]{2}{*}{ B-107 } & \multirow[t]{2}{*}{1.31} & \multirow[t]{2}{*}{$7.88 \mathrm{E}+06$} & \multirow[t]{2}{*}{$6.01 \mathrm{E}+06$} & $\mathrm{Al}$ & 1.8 & 1.4 & 0.79 & $16 \%$ & $\begin{array}{l}\text { Use of concentration from maximum-SOF layer; } \\
\text { toxicity increase (by assigning aluminum } \\
\text { hydroxide instead of sodium aluminum } \\
\text { carbonate hydroxide) }\end{array}$ \\
\hline & & & & $\mathrm{NO}_{3}$ & 1.5 & 1.5 & 1.00 & $87 \%$ & Use of concentration from maximum-SOF layer \\
\hline \multirow{4}{*}{ TX-108 } & \multirow{4}{*}{1.31} & \multirow{4}{*}{$1.53 \mathrm{E}+07$} & \multirow{4}{*}{$1.16 \mathrm{E}+07$} & $\mathrm{NO}_{3}$ & 0.13 & 0.13 & 1.02 & $-196 \%$ & \multirow{4}{*}{$\begin{array}{l}\text { Use of concentration from maximum-SOF layer. } \\
\text { In the case of } \mathrm{Al} \text {, there is also a toxicity decrease } \\
\text { (because } \mathrm{Al} \text { is generated by assigning } \mathrm{Si} \text { to } \\
\mathrm{NaAlSiO}_{4} \text { ) }\end{array}$} \\
\hline & & & & $\mathrm{Al}$ & 0.053 & 0.10 & 1.92 & $-17 \%$ & \\
\hline & & & & $\mathrm{Pb}$ & 3.0 & 3.0 & 1.00 & $15 \%$ & \\
\hline & & & & $\mathrm{U}$ & 35 & 35 & 1.00 & $314 \%$ & \\
\hline \multirow{6}{*}{ AW-104 } & \multirow{6}{*}{1.32} & \multirow{6}{*}{$1.14 \mathrm{E}+07$} & \multirow{6}{*}{$8.66 \mathrm{E}+06$} & U & 0.041 & 0.041 & 1.00 & $-35 \%$ & \multirow[t]{3}{*}{ Use of concentration from maximum-SOF layer } \\
\hline & & & & $\mathrm{NO}_{3}$ & 1.4 & 1.5 & 1.11 & $16 \%$ & \\
\hline & & & & $\mathrm{F}$ & 1.4 & 1.4 & 1.00 & $21 \%$ & \\
\hline & & & & TOC & 2.4 & 1.0 & 0.43 & $23 \%$ & $\begin{array}{l}\text { Increase is the result of toxicity change (by } \\
\text { assigning oxalate), not concentration change }\end{array}$ \\
\hline & & & & $\mathrm{NO}_{2}$ & 1.7 & 1.6 & 0.98 & $33 \%$ & Use of concentration from maximum-SOF layer \\
\hline & & & & $\mathrm{OH}$ & 1.7 & 1.6 & 0.98 & $40 \%$ & Same reason as $\mathrm{NO}_{2}$ (default scaled using $\mathrm{NO}_{2}$ ) \\
\hline
\end{tabular}


Table 4.6. (contd.)

\begin{tabular}{|c|c|c|c|c|c|c|c|c|c|}
\hline Tank & $\begin{array}{l}\text { New/Old } \\
\text { SOF-3 } \\
\text { Ratio }\end{array}$ & $\begin{array}{c}\text { New } \\
\text { SOF-3 }\end{array}$ & $\begin{array}{c}\text { Old } \\
\text { SOF-3 }\end{array}$ & Analyte & $\begin{array}{l}\text { New/Old } \\
\text { Contrib-3 } \\
\text { Ratio }\end{array}$ & $\begin{array}{l}\text { New/Old } \\
\text { Conc. } \\
\text { Ratio }\end{array}$ & $\begin{array}{l}\text { New/Old } \\
\text { Effective } \\
\text { TEEL-3 } \\
\text { Ratio }\end{array}$ & $\begin{array}{c}\text { Fraction of } \\
\text { SOF increase } \\
\text { from this } \\
\text { analyte }\end{array}$ & Comments \\
\hline \multirow{8}{*}{ BY-105 } & \multirow{8}{*}{1.34} & \multirow{8}{*}{$2.20 \mathrm{E}+07$} & \multirow{8}{*}{$1.64 \mathrm{E}+07$} & $\mathrm{NO}_{3}$ & 0.33 & 0.33 & 1.01 & $-143 \%$ & Use of concentration from maximum-SOF layer \\
\hline & & & & $\mathrm{Ca}$ & 0.30 & 1.9 & 6.2 & $-10 \%$ & $\begin{array}{l}\text { Primarily toxicity change (by assigning calcium } \\
\text { phosphate hydroxide instead of calcium } \\
\text { carbonate); also use of concentration from } \\
\text { maximum-SOF layer }\end{array}$ \\
\hline & & & & $\mathrm{NO}_{2}$ & 2.1 & 2.1 & 1.00 & $11 \%$ & \multirow{6}{*}{$\begin{array}{l}\text { Use of concentration from maximum-SOF layer } \\
\text { In the case of TOC, there is also an increase in } \\
\text { toxicity (by assigning oxalate). }\end{array}$} \\
\hline & & & & $\mathrm{Ni}$ & 8.2 & 8.2 & 1.00 & $27 \%$ & \\
\hline & & & & $\mathrm{OH}$ & 22 & 22 & 0.99 & $36 \%$ & \\
\hline & & & & $\mathrm{Sr}$ & 9.2 & 9.2 & 1.00 & $42 \%$ & \\
\hline & & & & TOC & 10 & 5.5 & 0.54 & $50 \%$ & \\
\hline & & & & $\mathrm{U}$ & 8.7 & 8.7 & 1.00 & $78 \%$ & \\
\hline \multirow{8}{*}{ BY-108 } & \multirow{8}{*}{1.36} & \multirow{8}{*}{$2.23 \mathrm{E}+07$} & \multirow{8}{*}{$1.65 \mathrm{E}+07$} & $\mathrm{NO}_{3}$ & 0.34 & 0.35 & 1.03 & $-57 \%$ & \multirow{8}{*}{$\begin{array}{l}\text { Use of concentration from maximum-SOF layer } \\
\mathrm{OH} \text { is default, scaled from } \mathrm{NO}_{2} \text {. In the case of } \\
\text { TOC, there is a toxicity decrease (by assigning } \\
\text { oxalate) }\end{array}$} \\
\hline & & & & $\mathrm{Al}$ & 0.26 & 0.27 & 1.05 & $-38 \%$ & \\
\hline & & & & $\mathrm{Ni}$ & 3.0 & 3.0 & 1.00 & $16 \%$ & \\
\hline & & & & $\mathrm{OH}$ & 1.4 & 1.4 & 0.99 & $16 \%$ & \\
\hline & & & & TOC & 3.4 & 1.9 & 0.55 & $21 \%$ & \\
\hline & & & & $\mathrm{Pb}$ & 3.1 & 3.1 & 1.00 & $21 \%$ & \\
\hline & & & & $\mathrm{Sr}$ & 3.9 & 3.9 & 1.00 & $31 \%$ & \\
\hline & & & & $\mathrm{U}$ & 3.8 & 3.8 & 1.00 & $82 \%$ & \\
\hline
\end{tabular}


Table 4.6. (contd.)

\begin{tabular}{|c|c|c|c|c|c|c|c|c|c|}
\hline Tank & $\begin{array}{c}\text { New/Old } \\
\text { SOF-3 } \\
\text { Ratio } \\
\end{array}$ & $\begin{array}{c}\text { New } \\
\text { SOF-3 } \\
\end{array}$ & $\begin{array}{c}\text { Old } \\
\text { SOF-3 } \\
\end{array}$ & Analyte & $\begin{array}{c}\text { New/Old } \\
\text { Contrib-3 } \\
\text { Ratio } \\
\end{array}$ & $\begin{array}{c}\text { New/Old } \\
\text { Conc. } \\
\text { Ratio } \\
\end{array}$ & $\begin{array}{c}\text { New/Old } \\
\text { Effective } \\
\text { TEEL-3 } \\
\text { Ratio } \\
\end{array}$ & $\begin{array}{c}\text { Fraction of } \\
\text { SOF increase } \\
\text { from this } \\
\text { analyte } \\
\end{array}$ & Comments \\
\hline \multirow{7}{*}{ BX-103 } & \multirow{7}{*}{1.36} & \multirow{7}{*}{$9.28 \mathrm{E}+06$} & \multirow{7}{*}{$6.80 \mathrm{E}+06$} & $\mathrm{Al}$ & 0.033 & 0.033 & 1.01 & $-79 \%$ & \multirow[t]{4}{*}{ Use of concentration from maximum-SOF layer } \\
\hline & & & & $\mathrm{Pb}$ & 0.52 & 0.52 & 1.00 & $-23 \%$ & \\
\hline & & & & $\mathrm{PO}_{4}$ & 3.4 & 3.4 & 0.99 & $13 \%$ & \\
\hline & & & & $\mathrm{NO}_{2}$ & 1.9 & 1.9 & 1.00 & $13 \%$ & \\
\hline & & & & TOC & 1.6 & 1.1 & 0.69 & $24 \%$ & $\begin{array}{l}\text { Increase is the result of toxicity change (by } \\
\text { assigning oxalate), not concentration change }\end{array}$ \\
\hline & & & & $\mathrm{U}$ & 3.0 & 3.0 & 1.00 & $39 \%$ & Use of concentration from maximum-SOF layer \\
\hline & & & & $\mathrm{NO}_{3}$ & 3.5 & 3.5 & 1.00 & $110 \%$ & \\
\hline \multirow{6}{*}{ S-107 } & \multirow{6}{*}{1.37} & \multirow{6}{*}{$9.93 \mathrm{E}+06$} & \multirow{6}{*}{$7.24 \mathrm{E}+06$} & $\mathrm{~F}$ & 1.4 & 1.4 & 1.00 & $10 \%$ & \multirow[t]{6}{*}{ Use of concentration from maximum-SOF layer } \\
\hline & & & & $\mathrm{Zr}$ & 1.4 & 1.4 & 1.00 & $10 \%$ & \\
\hline & & & & $\mathrm{U}$ & 1.4 & 1.4 & 1.00 & $12 \%$ & \\
\hline & & & & $\mathrm{NO}_{2}$ & 1.4 & 1.4 & 1.00 & $16 \%$ & \\
\hline & & & & $\mathrm{NO}_{3}$ & 1.4 & 1.4 & 1.01 & $16 \%$ & \\
\hline & & & & $\mathrm{Al}$ & 1.3 & 1.3 & 1.00 & $19 \%$ & \\
\hline \multirow{4}{*}{ SX-115 } & \multirow{4}{*}{1.37} & \multirow{4}{*}{$7.70 \mathrm{E}+06$} & \multirow{4}{*}{$5.60 \mathrm{E}+06$} & $\mathrm{Fe}$ & 0.56 & 0.56 & 1.00 & $-16 \%$ & $\begin{array}{l}\text { In old method, ESP input concentration was } \\
\text { increased for charge balance }\end{array}$ \\
\hline & & & & TOC & 2.2 & 1.1 & 0.51 & $6 \%$ & $\begin{array}{l}\text { Increase is the result of toxicity change (by } \\
\text { assigning oxalate), not concentration change }\end{array}$ \\
\hline & & & & $\mathrm{Al}$ & 1.1 & 1.1 & 1.01 & $8 \%$ & Difference in ESP and BBI bulk density \\
\hline & & & & $\mathrm{NO}_{3}$ & 2.6 & 2.6 & 0.99 & $88 \%$ & $\begin{array}{l}\text { In old method, ESP input concentration was } \\
\text { decreased for charge balance }\end{array}$ \\
\hline
\end{tabular}


Table 4.6. (contd.)

\begin{tabular}{|c|c|c|c|c|c|c|c|c|c|}
\hline Tank & $\begin{array}{c}\text { New/Old } \\
\text { SOF-3 } \\
\text { Ratio }\end{array}$ & $\begin{array}{c}\text { New } \\
\text { SOF-3 }\end{array}$ & $\begin{array}{c}\text { Old } \\
\text { SOF-3 }\end{array}$ & Analyte & $\begin{array}{l}\text { New/Old } \\
\text { Contrib-3 } \\
\text { Ratio } \\
\end{array}$ & $\begin{array}{l}\text { New/Old } \\
\text { Conc. } \\
\text { Ratio } \\
\end{array}$ & $\begin{array}{l}\text { New/Old } \\
\text { Effective } \\
\text { TEEL-3 } \\
\text { Ratio } \\
\end{array}$ & $\begin{array}{c}\text { Fraction of } \\
\text { SOF increase } \\
\text { from this } \\
\text { analyte } \\
\end{array}$ & Comments \\
\hline \multirow{4}{*}{ AN-107 } & \multirow{4}{*}{1.38} & \multirow{4}{*}{$1.14 \mathrm{E}+07$} & \multirow{4}{*}{$8.25 \mathrm{E}+06$} & $\mathrm{~Pb}$ & 0.26 & 0.26 & 1.00 & $-38 \%$ & \multirow{2}{*}{$\begin{array}{l}\text { Artifact of using an estimated solid fraction } \\
(0.13) \text { to convert old method from dry-solids } \\
\text { basis to bulk wet solids; also a difference in the } \\
\text { ESP and BBI solubilities. BBI is measured. }\end{array}$} \\
\hline & & & & $\mathrm{F}$ & 0.33 & 0.33 & 1.00 & $-15 \%$ & \\
\hline & & & & $\mathrm{Al}$ & 2.0 & 0.94 & 0.46 & $13 \%$ & $\begin{array}{l}\text { Increase is the result of toxicity change (by } \\
\text { assigning aluminum hydroxide, not sodium } \\
\text { aluminum carbonate dihydroxide), not } \\
\text { concentration change }\end{array}$ \\
\hline & & & & TOC & 17.3 & 1.1 & 0.061 & $140 \%$ & $\begin{array}{l}\text { Increase is the result of toxicity change (by } \\
\text { assigning oxalate), not concentration change }\end{array}$ \\
\hline \multirow{3}{*}{ AN-106 } & \multirow{3}{*}{1.38} & \multirow{3}{*}{$9.60 \mathrm{E}+06$} & \multirow{3}{*}{$6.94 \mathrm{E}+06$} & $\mathrm{CO}_{3}$ & 1.6 & 1.6 & 1.01 & $7 \%$ & \multirow{3}{*}{$\begin{array}{l}\text { Artifact of using an estimated solid fraction } \\
(0.13) \text { to convert old method from dry-solids } \\
\text { basis to bulk wet solids; also a difference in the } \\
\text { ESP and BBI solubilities. BBI uses estimate for } \\
\text { solids. }\end{array}$} \\
\hline & & & & $\mathrm{NO}_{3}$ & 1.6 & 1.6 & 1.01 & $30 \%$ & \\
\hline & & & & $\mathrm{NO}_{2}$ & 1.9 & 1.9 & 0.97 & $61 \%$ & \\
\hline B-111 & 1.39 & $5.00 \mathrm{E}+06$ & $3.61 \mathrm{E}+06$ & $\mathrm{~Pb}$ & 82 & 0.89 & 0.011 & $103 \%$ & $\begin{array}{l}\text { Increase is the result of toxicity change (by } \\
\text { assigning lead hydroxide rather than lead } \\
\text { carbonate), not concentration change }\end{array}$ \\
\hline C-108 & 1.41 & $8.98 E+06$ & $6.38 \mathrm{E}+06$ & $\mathrm{~Pb}$ & 3.4 & 3.4 & 1.00 & $88 \%$ & Use of concentration from maximum-SOF layer \\
\hline \multirow{3}{*}{ C-111 } & \multirow{3}{*}{1.41} & \multirow{3}{*}{$2.00 \mathrm{E}+07$} & \multirow{3}{*}{$1.41 \mathrm{E}+07$} & $\mathrm{NO}_{3}$ & 1.5 & 1.5 & 0.99 & $7 \%$ & \multirow{2}{*}{$\begin{array}{l}\text { Use of concentration from maximum-SOF layer } \\
\text { In addition, in the old method the } \mathrm{NO}_{3} \text { input to } \\
\text { ESP was adjusted down to reach charge balance. }\end{array}$} \\
\hline & & & & $\mathrm{NO}_{2}$ & 1.7 & 1.7 & 0.98 & $14 \%$ & \\
\hline & & & & $\mathrm{Pb}$ & 2.4 & 1.1 & 0.45 & $64 \%$ & $\begin{array}{l}\text { Toxicity change (by assigning lead hydroxide in } \\
\text { the solid instead of part lead hydroxide and part } \\
\text { lead phosphate) }\end{array}$ \\
\hline
\end{tabular}


Table 4.6. (contd.)

\begin{tabular}{|c|c|c|c|c|c|c|c|c|c|}
\hline Tank & $\begin{array}{l}\text { New/Old } \\
\text { SOF-3 } \\
\text { Ratio }\end{array}$ & $\begin{array}{l}\text { New } \\
\text { SOF-3 }\end{array}$ & $\begin{array}{l}\text { Old } \\
\text { SOF-3 }\end{array}$ & Analyte & $\begin{array}{l}\text { New/Old } \\
\text { Contrib-3 } \\
\text { Ratio }\end{array}$ & $\begin{array}{l}\text { New/Old } \\
\text { Conc. } \\
\text { Ratio }\end{array}$ & $\begin{array}{l}\text { New/Old } \\
\text { Effective } \\
\text { TEEL-3 } \\
\text { Ratio }\end{array}$ & $\begin{array}{c}\text { Fraction of } \\
\text { SOF increase } \\
\text { from this } \\
\text { analyte }\end{array}$ & Comments \\
\hline \multirow{2}{*}{$\mathrm{U}-112$} & \multirow{2}{*}{1.43} & \multirow{2}{*}{$1.26 \mathrm{E}+07$} & \multirow{2}{*}{$8.82 \mathrm{E}+06$} & $\mathrm{~Pb}$ & 2.8 & 2.8 & 1.00 & $47 \%$ & \multirow[t]{2}{*}{ Use of concentration from maximum-SOF layer } \\
\hline & & & & $\mathrm{Al}$ & 1.5 & 1.4 & 0.98 & $60 \%$ & \\
\hline \multirow{5}{*}{ U-105 } & \multirow{5}{*}{1.45} & \multirow{5}{*}{$2.12 \mathrm{E}+07$} & \multirow{5}{*}{$1.46 \mathrm{E}+07$} & $\mathrm{NO}_{3}$ & 0.47 & 0.47 & 1.00 & $-64 \%$ & \multirow[t]{2}{*}{ Use of concentration from maximum-SOF layer } \\
\hline & & & & $\mathrm{NO}_{2}$ & 0.46 & 0.46 & 0.99 & $-15 \%$ & \\
\hline & & & & TOC & 2.4 & 0.53 & 0.22 & $17 \%$ & $\begin{array}{l}\text { Increase is the result of toxicity change (by } \\
\text { assigning oxalate), not concentration change }\end{array}$ \\
\hline & & & & $\mathrm{Al}$ & 4.5 & 4.5 & 0.99 & $71 \%$ & Use of concentration from maximum-SOF layer \\
\hline & & & & $\mathrm{U}$ & 7.2 & 7.2 & 1.00 & $97 \%$ & \\
\hline \multirow{8}{*}{ BY-112 } & 1.46 & $2.14 \mathrm{E}+08$ & $1.47 \mathrm{E}+08$ & $\mathrm{~Pb}$ & 1.6 & 0.80 & 0.50 & $109 \%$ & $\begin{array}{l}\text { Toxicity change (by assigning lead hydroxide in } \\
\text { the solid instead of part lead hydroxide and part } \\
\text { lead carbonate) }\end{array}$ \\
\hline & \multirow{7}{*}{1.46} & \multirow{7}{*}{$1.66 \mathrm{E}+07$} & \multirow{7}{*}{$1.14 \mathrm{E}+07$} & TOC & 0.074 & 0.072 & 0.98 & $-31 \%$ & \multirow{7}{*}{$\begin{array}{l}\text { Use of concentration from maximum-SOF layer. } \\
\text { In the case of Al, there is also a toxicity decrease } \\
\text { (because } \mathrm{Al} \text { is generated by assigning } \mathrm{Si} \text { to } \\
\mathrm{NaAlSiO}_{4} \text { ) }\end{array}$} \\
\hline & & & & Cr(III) & 0.081 & 0.081 & 1.00 & $-21 \%$ & \\
\hline & & & & $\mathrm{CO}_{3}$ & 0.089 & 0.089 & 1.00 & $-20 \%$ & \\
\hline & & & & $\mathrm{NO}_{3}$ & 0.52 & 0.53 & 1.02 & $-18 \%$ & \\
\hline & & & & $\mathrm{Al}$ & 0.043 & 0.088 & 2.1 & $-15 \%$ & \\
\hline & & & & $\mathrm{Pb}$ & 5.1 & 5.1 & 1.00 & $12 \%$ & \\
\hline & & & & $\mathrm{U}$ & 63 & 63 & 1.00 & $223 \%$ & \\
\hline \multirow{4}{*}{$\mathrm{T}-105$} & \multirow{4}{*}{1.47} & \multirow{4}{*}{$8.01 \mathrm{E}+06$} & \multirow{4}{*}{$5.45 \mathrm{E}+06$} & $\mathrm{~Pb}$ & 0.54 & 0.54 & 1.00 & $-16 \%$ & \multirow{4}{*}{$\begin{array}{l}\text { Use of concentration from maximum-SOF layer. } \\
\text { In the case of TOC, there is also a toxicity } \\
\text { increase (by assigning oxalate) }\end{array}$} \\
\hline & & & & U & 2.4 & 2.4 & 1.00 & $15 \%$ & \\
\hline & & & & TOC & 3.3 & 1.7 & 0.53 & $18 \%$ & \\
\hline & & & & $\mathrm{Al}$ & 2.7 & 2.4 & 0.91 & $85 \%$ & \\
\hline
\end{tabular}


Table 4.6. (contd.)

\begin{tabular}{|c|c|c|c|c|c|c|c|c|c|}
\hline Tank & $\begin{array}{c}\text { New/Old } \\
\text { SOF-3 } \\
\text { Ratio } \\
\end{array}$ & $\begin{array}{c}\text { New } \\
\text { SOF-3 } \\
\end{array}$ & $\begin{array}{c}\text { Old } \\
\text { SOF-3 } \\
\end{array}$ & Analyte & $\begin{array}{c}\text { New/Old } \\
\text { Contrib-3 } \\
\text { Ratio } \\
\end{array}$ & $\begin{array}{l}\text { New/Old } \\
\text { Conc. } \\
\text { Ratio } \\
\end{array}$ & $\begin{array}{c}\text { New/Old } \\
\text { Effective } \\
\text { TEEL-3 } \\
\text { Ratio } \\
\end{array}$ & $\begin{array}{c}\text { Fraction of } \\
\text { SOF increase } \\
\text { from this } \\
\text { analyte } \\
\end{array}$ & Comments \\
\hline \multirow{7}{*}{ BY-104 } & \multirow{7}{*}{1.52} & \multirow{7}{*}{$1.96 \mathrm{E}+07$} & \multirow{7}{*}{$1.29 \mathrm{E}+07$} & $\mathrm{NO}_{3}$ & 0.51 & 0.53 & 1.02 & $-39 \%$ & \multirow{7}{*}{$\begin{array}{l}\text { Use of concentration from maximum-SOF layer } \\
\text { In the case of TOC, there is also a toxicity } \\
\text { increase (by assigning oxalate) }\end{array}$} \\
\hline & & & & $\mathrm{Pb}$ & 3.4 & 3.4 & 1.00 & $12 \%$ & \\
\hline & & & & $\mathrm{Al}$ & 1.7 & 1.8 & 1.02 & $14 \%$ & \\
\hline & & & & TOC & 2.4 & 1.5 & 0.63 & $18 \%$ & \\
\hline & & & & $\mathrm{Ni}$ & 5.4 & 5.4 & 1.00 & $18 \%$ & \\
\hline & & & & $\mathrm{Sr}$ & 5.6 & 5.6 & 1.00 & $28 \%$ & \\
\hline & & & & U & 5.6 & 5.6 & 1.00 & $52 \%$ & \\
\hline \multirow{3}{*}{ BY-109 } & \multirow{3}{*}{1.56} & \multirow{3}{*}{$1.29 \mathrm{E}+07$} & \multirow{3}{*}{$8.27 \mathrm{E}+06$} & $\mathrm{~F}$ & 0.022 & 0.022 & 1.00 & $-36 \%$ & \multirow{3}{*}{$\begin{array}{l}\text { Use of concentration from maximum-SOF layer. } \\
\text { In the case of TOC, there is also a toxicity } \\
\text { increase (by assigning oxalate) }\end{array}$} \\
\hline & & & & TOC & 0.18 & 0.15 & 0.82 & $-15 \%$ & \\
\hline & & & & $\mathrm{Al}$ & 5.8 & 5.5 & 0.95 & $163 \%$ & \\
\hline \multirow{5}{*}{ U-110 } & \multirow{5}{*}{1.57} & \multirow{5}{*}{$1.14 \mathrm{E}+07$} & \multirow{5}{*}{$7.26 \mathrm{E}+06$} & $\mathrm{OH}$ & 2.0 & 2.0 & 0.99 & $11 \%$ & \multirow[t]{5}{*}{$\begin{array}{l}\text { Use of concentration from maximum-SOF layer } \\
\mathrm{OH} \text { is default, scaled from } \mathrm{NO}_{2} \text {. }\end{array}$} \\
\hline & & & & $\mathrm{NO}_{3}$ & 1.8 & 1.8 & 1.01 & $12 \%$ & \\
\hline & & & & $\mathrm{Pb}$ & 1.7 & 1.7 & 1.00 & $13 \%$ & \\
\hline & & & & $\mathrm{U}$ & 1.5 & 1.5 & 1.00 & $23 \%$ & \\
\hline & & & & $\mathrm{Al}$ & 1.4 & 1.4 & 1.00 & $25 \%$ & \\
\hline
\end{tabular}


Table 4.6. (contd.)

\begin{tabular}{|c|c|c|c|c|c|c|c|c|c|}
\hline Tank & \begin{tabular}{|c|} 
New/Old \\
SOF-3 \\
Ratio
\end{tabular} & $\begin{array}{c}\text { New } \\
\text { SOF-3 }\end{array}$ & $\begin{array}{c}\text { Old } \\
\text { SOF-3 }\end{array}$ & Analyte & $\begin{array}{l}\text { New/Old } \\
\text { Contrib-3 } \\
\text { Ratio } \\
\end{array}$ & $\begin{array}{l}\text { New/Old } \\
\text { Conc. } \\
\text { Ratio } \\
\end{array}$ & $\begin{array}{c}\text { New/Old } \\
\text { Effective } \\
\text { TEEL-3 } \\
\text { Ratio } \\
\end{array}$ & $\begin{array}{c}\text { Fraction of } \\
\text { SOF increase } \\
\text { from this } \\
\text { analyte } \\
\end{array}$ & Comments \\
\hline \multirow{8}{*}{ A-101 } & \multirow{8}{*}{1.58} & \multirow{8}{*}{$2.10 \mathrm{E}+07$} & \multirow{8}{*}{$1.33 \mathrm{E}+07$} & $\mathrm{~N}_{\mathrm{NO}}$ & (20.25 & (20.25 & " 1.00 & "-44\% & \multirow{8}{*}{$\begin{array}{l}\text { Use of concentration from maximum-SOF layer } \\
\mathrm{OH} \text { is default, scaled from } \mathrm{NO}_{2} \text {. In the case of } \\
\mathrm{Al} \text {, there is a toxicity decrease (because part of } \\
\text { the } \mathrm{Al} \text { is in } \mathrm{NaAlSiO}_{4} \text {, which is the compound } \\
\text { assigned to } \mathrm{Si} \text { ) }\end{array}$} \\
\hline & & & & $\mathrm{NO}_{2}$ & 0.026 & 0.026 & 0.99 & $-40 \%$ & \\
\hline & & & & $\mathrm{OH}$ & 0.027 & 0.026 & 0.99 & $-25 \%$ & \\
\hline & & & & TOC & 0 & 0 & undefined & $-12 \%$ & \\
\hline & & & & $\mathrm{La}$ & 21 & 21 & 1.00 & $15 \%$ & \\
\hline & & & & $\mathrm{Ni}$ & 44 & 44 & 1.00 & $18 \%$ & \\
\hline & & & & $\mathrm{Al}$ & 4.7 & 5.9 & 1.3 & $49 \%$ & \\
\hline & & & & $\mathrm{Pb}$ & 28 & 28 & 1.00 & $132 \%$ & \\
\hline \multirow{4}{*}{ S-109 } & \multirow{4}{*}{1.60} & \multirow{4}{*}{$2.22 \mathrm{E}+07$} & \multirow{4}{*}{$1.39 \mathrm{E}+07$} & $\mathrm{NO}_{3}$ & 0.22 & 0.22 & 1.01 & $-109 \%$ & \multirow{4}{*}{$\begin{array}{l}\text { Use of concentration from maximum-SOF layer. } \\
\text { OH is default, scaled from } \mathrm{NO}_{2} \text {. A further } \\
\text { increase because, in the old method, the inputs } \\
\text { to ESP were diluted by } 20 \% \text { to make the model } \\
\text { converge. }\end{array}$} \\
\hline & & & & $\mathrm{NO}_{2}$ & 7.1 & 7.1 & 1.00 & $17 \%$ & \\
\hline & & & & $\mathrm{Al}$ & 29 & 29 & 1.01 & $67 \%$ & \\
\hline & & & & $\mathrm{OH}$ & 7.1 & 7.1 & 1.00 & $106 \%$ & \\
\hline \multirow{4}{*}{ B-108 } & \multirow{4}{*}{1.62} & \multirow{4}{*}{$1.26 \mathrm{E}+07$} & \multirow{4}{*}{$7.80 \mathrm{E}+06$} & $\mathrm{~F}$ & 0.54 & 0.54 & 1.00 & $-14 \%$ & \multirow{4}{*}{$\begin{array}{l}\text { Use of concentration from maximum-SOF layer. } \\
\text { A further increase because, in the old method, } \\
\text { the inputs to ESP were diluted by } 10 \% \text { to make } \\
\text { the model converge. }\end{array}$} \\
\hline & & & & $\mathrm{NO}_{2}$ & 2.4 & 2.4 & 0.99 & $7 \%$ & \\
\hline & & & & $\mathrm{Pb}$ & 2.5 & 2.5 & 1.00 & $31 \%$ & \\
\hline & & & & $\mathrm{Al}$ & 2.6 & 2.6 & 1.00 & $72 \%$ & \\
\hline \multirow{6}{*}{ BY-101 } & \multirow{6}{*}{1.63} & \multirow{6}{*}{$1.95 \mathrm{E}+07$} & \multirow{6}{*}{$1.19 \mathrm{E}+07$} & $\mathrm{NO}_{3}$ & 0.15 & 0.15 & 1.01 & $-86 \%$ & \multirow{6}{*}{$\begin{array}{l}\text { Use of concentration from maximum-SOF layer. } \\
\text { A further increase because, in the old method, } \\
\text { the inputs to ESP were diluted by } 10 \% \text { to make } \\
\text { the model converge. }\end{array}$} \\
\hline & & & & $\mathrm{NO}_{2}$ & 7.2 & 7.1 & 0.99 & $20 \%$ & \\
\hline & & & & $\mathrm{Ni}$ & 9.3 & 9.3 & 1.00 & $25 \%$ & \\
\hline & & & & $\mathrm{Pb}$ & 7.3 & 7.3 & 1.00 & $36 \%$ & \\
\hline & & & & $\mathrm{U}$ & 9.1 & 9.1 & 1.00 & $52 \%$ & \\
\hline & & & & $\mathrm{OH}$ & 6.3 & 6.2 & 0.99 & $53 \%$ & \\
\hline
\end{tabular}


Table 4.6. (contd.)

\begin{tabular}{|c|c|c|c|c|c|c|c|c|c|}
\hline Tank & $\begin{array}{c}\text { New/Old } \\
\text { SOF-3 } \\
\text { Ratio }\end{array}$ & $\begin{array}{c}\text { New } \\
\text { SOF-3 }\end{array}$ & $\begin{array}{c}\text { Old } \\
\text { SOF-3 }\end{array}$ & Analyte & $\begin{array}{c}\text { New/Old } \\
\text { Contrib-3 } \\
\text { Ratio }\end{array}$ & $\begin{array}{c}\text { New/Old } \\
\text { Conc. } \\
\text { Ratio }\end{array}$ & $\begin{array}{l}\text { New/Old } \\
\text { Effective } \\
\text { TEEL-3 } \\
\text { Ratio }\end{array}$ & $\begin{array}{c}\text { Fraction of } \\
\text { SOF increase } \\
\text { from this } \\
\text { analyte }\end{array}$ & Comments \\
\hline \multirow{3}{*}{$\mathrm{T}-103$} & \multirow{3}{*}{1.72} & \multirow{3}{*}{$1.53 \mathrm{E}+07$} & \multirow{3}{*}{$8.90 \mathrm{E}+06$} & $\mathrm{Al}$ & 0.0083 & 0.017 & 2.1 & $-66 \%$ & \multirow{3}{*}{$\begin{array}{l}\text { Use of concentration from maximum-SOF layer } \\
\text { In the case of } \mathrm{Al} \text {, there is a toxicity decrease } \\
\text { (because the } \mathrm{Al} \text { is generated as part of } \\
\mathrm{NaAlSiO}_{4} \text {, which is the compound assigned to } \\
\mathrm{Si} \text { ) }\end{array}$} \\
\hline & & & & $\mathrm{Pb}$ & 0.36 & 0.36 & 1.00 & $-22 \%$ & \\
\hline & & & & $\mathrm{U}$ & 17 & 17 & 1.00 & $175 \%$ & \\
\hline \multirow{6}{*}{ BY-107 } & \multirow{6}{*}{1.79} & \multirow{6}{*}{$2.11 \mathrm{E}+07$} & \multirow{6}{*}{$1.18 \mathrm{E}+07$} & $\mathrm{NO}_{3}$ & 0.50 & 0.51 & 1.03 & $-24 \%$ & \multirow[t]{6}{*}{ Use of concentration from maximum-SOF layer } \\
\hline & & & & TOC & 2.3 & 2.1 & 0.93 & $10 \%$ & \\
\hline & & & & $\mathrm{Sr}$ & 16 & 16 & 1.00 & $16 \%$ & \\
\hline & & & & $\mathrm{Ni}$ & 16 & 16 & 1.00 & $16 \%$ & \\
\hline & & & & $\mathrm{Pb}$ & 9.5 & 9.5 & 1.00 & $20 \%$ & \\
\hline & & & & $\mathrm{U}$ & 12 & 12 & 1.00 & $51 \%$ & \\
\hline \multirow{5}{*}{ TX-118 } & \multirow{5}{*}{1.82} & \multirow{5}{*}{$9.42 \mathrm{E}+06$} & \multirow{5}{*}{$5.16 \mathrm{E}+06$} & $\mathrm{NO}_{3}$ & 0.26 & 0.27 & 1.03 & $-14 \%$ & \multirow{5}{*}{$\begin{array}{l}\text { Use of concentration from maximum-SOF layer } \\
\text { In addition, } \mathrm{Cr}(\mathrm{VI}) \text { is increased because the } \mathrm{Cr} \\
\text { wash fraction used to estimate } \mathrm{Cr}(\mathrm{VI}) \text { by the } \\
\text { new method is greater than the } \mathrm{Cr}(\mathrm{VI}) / \mathrm{Cr} \text { split } \\
\text { used in the old. In the case of TOC, there is a } \\
\text { toxicity increase (by assigning oxalate). }\end{array}$} \\
\hline & & & & $\mathrm{U}$ & 2.8 & 2.8 & 1.00 & $8 \%$ & \\
\hline & & & & $\mathrm{Cr}(\mathrm{VI})$ & 7.9 & 7.9 & 1.00 & $12 \%$ & \\
\hline & & & & $\mathrm{Pb}$ & 3.1 & 3.1 & 1.00 & $19 \%$ & \\
\hline & & & & TOC & 3.6 & 2.9 & 0.79 & $69 \%$ & \\
\hline \multirow{2}{*}{ C-107 } & \multirow{2}{*}{1.85} & \multirow{2}{*}{$2.34 \mathrm{E}+07$} & \multirow{2}{*}{$1.26 \mathrm{E}+07$} & $\mathrm{Al}$ & 3.3 & 3.2 & 0.98 & $28 \%$ & \multirow[t]{2}{*}{ Use of concentration from maximum-SOF layer. } \\
\hline & & & & $\mathrm{Pb}$ & 1.9 & 1.9 & 1.00 & $63 \%$ & \\
\hline \multirow{6}{*}{ BY-106 } & \multirow{6}{*}{1.99} & \multirow{6}{*}{$2.47 \mathrm{E}+07$} & \multirow{6}{*}{$1.24 \mathrm{E}+07$} & $\mathrm{NO}_{3}$ & 0.32 & 0.33 & 1.03 & $-38 \%$ & \multirow{6}{*}{$\begin{array}{l}\text { Use of concentration from maximum-SOF layer } \\
\text { In the case of TOC, there is also a toxicity } \\
\text { increase (by assigning oxalate) }\end{array}$} \\
\hline & & & & $\mathrm{Sr}$ & 13 & 13 & 1.00 & $13 \%$ & \\
\hline & & & & $\mathrm{Pb}$ & 7.8 & 7.8 & 1.00 & $14 \%$ & \\
\hline & & & & TOC & 8.4 & 5.3 & 0.63 & $27 \%$ & \\
\hline & & & & $\mathrm{U}$ & 12 & 12 & 1.00 & $32 \%$ & \\
\hline & & & & $\mathrm{Ni}$ & 13 & 13 & 1.00 & $39 \%$ & \\
\hline
\end{tabular}


Table 4.6. (contd.)

\begin{tabular}{|c|c|c|c|c|c|c|c|c|c|}
\hline Tank & $\begin{array}{l}\text { New/Old } \\
\text { SOF-3 } \\
\text { Ratio } \\
\end{array}$ & $\begin{array}{c}\text { New } \\
\text { SOF-3 } \\
\end{array}$ & $\begin{array}{c}\text { Old } \\
\text { SOF-3 } \\
\end{array}$ & Analyte & $\begin{array}{c}\text { New/Old } \\
\text { Contrib-3 } \\
\text { Ratio } \\
\end{array}$ & $\begin{array}{l}\text { New/Old } \\
\text { Conc. } \\
\text { Ratio } \\
\end{array}$ & $\begin{array}{c}\text { New/Old } \\
\text { Effective } \\
\text { TEEL-3 } \\
\text { Ratio } \\
\end{array}$ & $\begin{array}{c}\text { Fraction of } \\
\text { SOF increase } \\
\text { from this } \\
\text { analyte } \\
\end{array}$ & Comments \\
\hline \multirow{5}{*}{ BY-110 } & \multirow{5}{*}{2.00} & \multirow{5}{*}{$2.10 \mathrm{E}+07$} & \multirow{5}{*}{$1.05 \mathrm{E}+07$} & TOC & 3.3 & 1.5 & 0.47 & $12 \%$ & $\begin{array}{l}\text { Increase is primarily the result of toxicity change } \\
\text { (by assigning oxalate), not concentration change }\end{array}$ \\
\hline & & & & $\mathrm{Sr}$ & 6.9 & 6.9 & 1.00 & $13 \%$ & \multirow[t]{4}{*}{ Use of concentration from maximum-SOF layer. } \\
\hline & & & & $\mathrm{Ni}$ & 4.8 & 4.8 & 1.00 & $13 \%$ & \\
\hline & & & & $\mathrm{Pb}$ & 4.7 & 4.7 & 1.00 & $24 \%$ & \\
\hline & & & & $\mathrm{U}$ & 6.2 & 6.2 & 1.00 & $37 \%$ & \\
\hline \multirow{5}{*}{ AX-103 } & \multirow{5}{*}{2.05} & \multirow{5}{*}{$2.00 \mathrm{E}+07$} & \multirow{5}{*}{$9.76 \mathrm{E}+06$} & $\mathrm{NO}_{2}$ & 0.035 & 0.034 & 0.99 & $-27 \%$ & \multirow{5}{*}{$\begin{array}{l}\text { Use of concentration from maximum-SOF layer. } \\
\mathrm{OH} \text { is default, scaled from } \mathrm{NO}_{2} \text {. }\end{array}$} \\
\hline & & & & $\mathrm{OH}$ & 0.036 & 0.035 & 0.99 & $-13 \%$ & \\
\hline & & & & $\mathrm{Ni}$ & 10 & 10 & 1.00 & $8 \%$ & \\
\hline & & & & $\mathrm{La}$ & 9.7 & 9.7 & 1.00 & $13 \%$ & \\
\hline & & & & $\mathrm{Pb}$ & 9.7 & 9.7 & 1.00 & $114 \%$ & \\
\hline \multirow{3}{*}{ S-112 } & \multirow{3}{*}{2.16} & \multirow{3}{*}{$3.30 \mathrm{E}+07$} & \multirow{3}{*}{$1.53 \mathrm{E}+07$} & $\mathrm{NO}_{3}$ & 0.23 & 0.23 & 1.01 & $-48 \%$ & \multirow[t]{3}{*}{ Use of concentration from maximum-SOF layer. } \\
\hline & & & & $\mathrm{Al}$ & 16 & 15 & 0.92 & $30 \%$ & \\
\hline & & & & $\mathrm{OH}$ & 15 & 15 & 1.00 & $111 \%$ & \\
\hline \multirow{3}{*}{ SX-114 } & \multirow{3}{*}{2.27} & \multirow{3}{*}{$3.31 \mathrm{E}+07$} & \multirow{3}{*}{$1.46 \mathrm{E}+07$} & $\mathrm{NO}_{3}$ & 0.46 & 0.47 & 1.01 & $-16 \%$ & \multirow[t]{3}{*}{ Use of concentration from maximum-SOF layer. } \\
\hline & & & & $\mathrm{Al}$ & 1.5 & 1.5 & 1.00 & $10 \%$ & \\
\hline & & & & $\mathrm{OH}$ & 9.5 & 9.5 & 1.00 & $102 \%$ & \\
\hline BX-105 & 2.40 & $1.55 \mathrm{E}+07$ & $6.45 \mathrm{E}+06$ & $\mathrm{U}$ & 5.9 & 5.9 & 1.00 & $109 \%$ & Use of concentration from maximum-SOF layer. \\
\hline \multirow{4}{*}{ A-104 } & \multirow{4}{*}{2.58} & \multirow{4}{*}{$2.26 \mathrm{E}+07$} & \multirow{4}{*}{$8.78 \mathrm{E}+06$} & $\mathrm{OH}$ & 0.14 & 0.14 & 1.00 & $-18 \%$ & \multirow{4}{*}{$\begin{array}{l}\text { Use of concentration from maximum-SOF layer. } \\
\mathrm{OH} \text { is default, scaled from } \mathrm{NO}_{2} \text {. }\end{array}$} \\
\hline & & & & $\mathrm{NO}_{3}$ & 25 & 25 & 1.01 & $10 \%$ & \\
\hline & & & & $\mathrm{La}$ & 25 & 25 & 1.00 & $10 \%$ & \\
\hline & & & & $\mathrm{Pb}$ & 24 & 24 & 1.00 & $89 \%$ & \\
\hline
\end{tabular}


Table 4.6. (contd.)

\begin{tabular}{|c|c|c|c|c|c|c|c|c|c|}
\hline Tank & \begin{tabular}{|c} 
New/Old \\
SOF-3 \\
Ratio \\
\end{tabular} & $\begin{array}{l}\text { New } \\
\text { SOF-3 }\end{array}$ & $\begin{array}{c}\text { Old } \\
\text { SOF-3 } \\
\end{array}$ & Analyte & $\begin{array}{c}\text { New/Old } \\
\text { Contrib-3 } \\
\text { Ratio } \\
\end{array}$ & $\begin{array}{l}\text { New/Old } \\
\text { Conc. } \\
\text { Ratio } \\
\end{array}$ & $\begin{array}{c}\text { New/Old } \\
\text { Effective } \\
\text { TEEL-3 } \\
\text { Ratio } \\
\end{array}$ & $\begin{array}{c}\text { Fraction of } \\
\text { SOF increase } \\
\text { from this } \\
\text { analyte } \\
\end{array}$ & Comments \\
\hline \multirow{5}{*}{ SX-113 } & \multirow{5}{*}{2.62} & \multirow{5}{*}{$5.18 \mathrm{E}+06$} & \multirow{5}{*}{$1.98 \mathrm{E}+06$} & Si & 0 & 0 & undefined & $-29 \%$ & $\begin{array}{l}\text { Zeroed because all } \mathrm{Si} \text { was assigned to } \mathrm{NaAlSiO}_{4} \text {, } \\
\text { which is credited to } \mathrm{Al} \text { for the purpose of this } \\
\text { table }\end{array}$ \\
\hline & & & & $\mathrm{U}$ & 4.3 & 4.3 & 1.00 & $7 \%$ & Use of concentration from maximum-SOF layer. \\
\hline & & & & $\mathrm{NO}_{2}$ & undefined & undefined & undefined & $23 \%$ & $\begin{array}{l}\text { In old method, charge balance in postprocessing } \\
\text { caused this concentration to be zeroed }\end{array}$ \\
\hline & & & & $\mathrm{NO}_{3}$ & undefined & undefined & undefined & $34 \%$ & \begin{tabular}{|l|} 
In old method, charge balance in postprocessing \\
caused this concentration to be zeroed
\end{tabular} \\
\hline & & & & $\mathrm{Al}$ & 5.7 & 2.6 & 0.46 & $64 \%$ & $\begin{array}{l}\text { Use of concentration from maximum-SOF layer; } \\
\text { toxicity increased because Al was present in } \\
\mathrm{NaAlSiO}_{4} \text { in old method, but was assigned to } \\
\mathrm{Al}(\mathrm{OH})_{3} \text { in new method. }\end{array}$ \\
\hline \multirow[t]{2}{*}{ B-103 } & \multirow[t]{2}{*}{2.66} & \multirow[t]{2}{*}{$1.56 \mathrm{E}+07$} & \multirow[t]{2}{*}{$5.86 \mathrm{E}+06$} & $\mathrm{Al}$ & 0.026 & 0.056 & 2.1 & $-14 \%$ & $\begin{array}{l}\text { In the maximum-SOF layer, the only } \mathrm{Al} \text { comes } \\
\text { as part of } \mathrm{NaAlSiO}_{4} \text { (the compound assigned to } \\
\mathrm{Si} \text { ). The toxicity decrease is based on the } \\
\text { difference between the old } \mathrm{Al}(\mathrm{OH})_{3} \text { and the new } \\
\mathrm{NaAlSiO}_{4} \text {. }\end{array}$ \\
\hline & & & & $\mathrm{U}$ & 22 & 22 & 1.00 & $116 \%$ & Use of concentration from maximum-SOF layer. \\
\hline \multirow[b]{3}{*}{ U-104 } & \multirow[b]{3}{*}{2.68} & \multirow[b]{3}{*}{$1.20 \mathrm{E}+07$} & \multirow[b]{3}{*}{ 4.47E+06 } & $\mathrm{NO}_{2}$ & 1.7 & 1.7 & 1.00 & $9 \%$ & \multirow[t]{2}{*}{ Use of concentration from maximum-SOF layer. } \\
\hline & & & & $\mathrm{NO}_{3}$ & 1.6 & 1.6 & 1.00 & $13 \%$ & \\
\hline & & & & $\mathrm{Al}$ & 5.6 & 3.5 & 0.62 & $63 \%$ & $\begin{array}{l}\text { Use of concentration from maximum-SOF layer. } \\
\text { The toxicity increase in } \mathrm{Al} \text { appears because part } \\
\text { of the } \mathrm{Al} \text { in the old method was } \mathrm{NaAlSiO}_{4} \text {, but } \\
\text { in the new method is } \mathrm{Al}(\mathrm{OH})_{3} \text {. }\end{array}$ \\
\hline \multirow{3}{*}{ BX-102 } & \multirow{3}{*}{3.61} & \multirow{3}{*}{$9.70 \mathrm{E}+06$} & \multirow{3}{*}{$2.69 \mathrm{E}+06$} & $\mathrm{NO}_{3}$ & 4.3 & 4.3 & 1.02 & $6 \%$ & Use of concentration from maximum-SOF layer. \\
\hline & & & & $\mathrm{Pb}$ & 213 & 2.4 & 0.011 & $32 \%$ & $\begin{array}{l}\text { Toxicity change (by assigning lead hydroxide); } \\
\text { also use of concentration from max.-SOF layer. }\end{array}$ \\
\hline & & & & $\mathrm{Al}$ & 2.9 & 2.4 & 0.83 & $47 \%$ & Use of concentration from maximum-SOF layer. \\
\hline
\end{tabular}


Table 4.6. (contd.)

\begin{tabular}{|c|c|c|c|c|c|c|c|c|c|}
\hline Tank & \begin{tabular}{|c|} 
New/Old \\
SOF-3 \\
Ratio \\
\end{tabular} & $\begin{array}{c}\text { New } \\
\text { SOF-3 }\end{array}$ & $\begin{array}{c}\text { Old } \\
\text { SOF-3 }\end{array}$ & Analyte & $\begin{array}{c}\text { New/Old } \\
\text { Contrib-3 } \\
\text { Ratio } \\
\end{array}$ & $\begin{array}{c}\text { New/Old } \\
\text { Conc. } \\
\text { Ratio } \\
\end{array}$ & $\begin{array}{c}\text { New/Old } \\
\text { Effective } \\
\text { TEEL-3 } \\
\text { Ratio } \\
\end{array}$ & $\begin{array}{c}\text { Fraction of } \\
\text { SOF increase } \\
\text { from this } \\
\text { analyte }\end{array}$ & Comments \\
\hline \multirow{3}{*}{ U-108 } & \multirow{3}{*}{3.65} & \multirow{3}{*}{$6.80 \mathrm{E}+07$} & \multirow{3}{*}{$1.86 \mathrm{E}+07$} & $\mathrm{NO}_{3}$ & 0.079 & 0.080 & 1.00 & $-13 \%$ & \multirow[t]{3}{*}{ Use of concentration from maximum-SOF layer. } \\
\hline & & & & $\mathrm{U}$ & 11 & 11 & 1.00 & $19 \%$ & \\
\hline & & & & $\mathrm{Pb}$ & 11 & 11 & 1.00 & $97 \%$ & \\
\hline $\mathrm{T}-110$ & 4.22 & $9.57 \mathrm{E}+06$ & $2.27 \mathrm{E}+06$ & $\mathrm{La}$ & 37 & 37 & 1.00 & $101 \%$ & Use of concentration from maximum-SOF layer. \\
\hline C-102 & 4.52 & $1.52 \mathrm{E}+07$ & $3.37 \mathrm{E}+06$ & $\mathrm{U}$ & 25 & 26 & 1.01 & $96 \%$ & Use of concentration from maximum-SOF layer. \\
\hline C-204 & 11.51 & $1.06 \mathrm{E}+08$ & $9.18 \mathrm{E}+06$ & $\mathrm{~Pb}$ & 288 & 0.96 & 0.0033 & $100 \%$ & $\begin{array}{l}\text { Toxicity change (by assigning lead hydroxide in } \\
\text { the solid instead of lead carbonate) }\end{array}$ \\
\hline
\end{tabular}





\subsection{Conclusions}

A new method of calculation for the toxicological SOFs of Hanford tank waste was compared to the old method that had been applied in 2002 and 2003 (Cowley et al. [2003]). The comparison was based on the SOFs for the major tank waste constituents (Al, Bi, Ca, Cl, Cr, F, Fe, Hg, K, La, Mn, Na, Ni, $\mathrm{NO}_{2}, \mathrm{NO}_{3}$, $\mathrm{Pb}, \mathrm{PO}_{4}, \mathrm{Si}, \mathrm{SO}_{4}, \mathrm{Sr}, \mathrm{TOC}, \mathrm{U}$, and $\mathrm{Zr}$ ) as well as Ag. The May $2002 \mathrm{BBI}$ was the basis for waste compositions. The liquid-phase and wet bulk solids SOFs for TEEL-1, TEEL-2, and TEEL-3 were included.

It was found that 50 to $60 \%$ of the Hanford tanks had SOFs for which the new method is within $\pm 20 \%$ of the old method, while 15 to $20 \%$ of the tanks show a difference of more than $\pm 50 \%$. The SOFs are increased by the new method more often than they are decreased. These statements hold for both the liquid and wet bulk solids SOFs. Twelve tanks had SOFs that decreased (and therefore were possibly nonconservative) by more than 50\%; only in one tank were wet bulk solids SOFs decreased by more than $50 \%$. For perspective, an uncertainty of $20 \%$ in analyte concentrations is a reasonable expectation for compositions based on sample measurements, considering the uncertainties in sample concentration and density analyses and the variability of concentration within the waste. The overall uncertainty could be considerably greater in tanks that have not been sampled, for which the composition is based on process knowledge or a template (Place and Higley 2005).

A detailed semi-quantitative study was made to learn the reasons for method-related changes in SOFs at TEEL-3. This TEEL level was chosen because its new-method SOFs differed from old-method values somewhat more than at the other TEEL levels. Three aspects of the change in SOF calculation method were identified as the causes of significant changes (those exceeding 30\%) in liquid-phase SOFs for TEEL-3:

- In 16 of the 24 tanks in which significant increases occurred, the primary cause was a difference between the ESP-predicted and BBI solubility of one or more analytes (most often $\mathrm{NO}_{3}, \mathrm{NO}_{2}, \mathrm{OH}$, and $\mathrm{Al}$ ). This was also the primary cause of the major decreases in all 14 liquid SOFs that had more than a 30\% decrease. Section 3.3.2 contains a general discussion of this point.

- In 3 of the tanks in which significant increases occurred, the primary cause was the use of analyte concentrations from the maximum-SOF layer instead of the tank-average waste, as discussed in Section 3.3.1.

- In 5 of the tanks in which significant increases occurred, the primary cause was the increase in the effective toxicity of TOC that resulted from using oxalate to represent all TOC. (Detailed discussion can be found in Sections 3.1 and C.22.)

Several aspects of the change in SOF calculation method were the causes of significant changes (those exceeding 30\%) in wet bulk solid SOFs for TEEL-3:

- In 37 of the 45 tanks in which significant increases occurred, the primary cause was the use of the concentrations of the layer that had the maximum SOF in the tank instead of the tank-average waste.

- In all 5 of the tanks in which significant decreases occurred and in one of the tanks that showed an increase, the primary cause was a combination of solubility changes (ESP versus BBI) with differences in the calculated solid volume fraction used to put the old-method SOFs on the basis of 
wet bulk solids instead of dry solids. Section 4.1 discusses the uncertainty involved in making this basis change.

- In 4 of the tanks in which significant increases occurred, the primary cause was an increase in the effective toxicity of lead because of its assignment to the compound lead hydroxide.

- In 2 of the tanks in which significant increases occurred, the primary cause was an increase in the effective toxicity of TOC because of its assignment to oxalate.

- In one of the tanks in which significant increases occurred, the primary cause was charge-balance adjustments made to the ESP output in the old method. Section 3.3.5 discusses this effect.

The above list makes it appear that differences between ESP and BBI solubilities are not as important for wet bulk solids as they were for liquids. It is difficult to sort out the mingled effects of maximum-layer concentrations, solubility difference, solid fraction uncertainty, and (to a lesser extent) density differences. On the other hand, the variation of analyte concentration from one layer to another in a tank was often significant enough to make it clear that layer-selection was the reason for the concentration change from old to new method.

Taking the results for liquid and wet bulk solids SOFs together, it is clear that the use of the maximumlayer approach is the dominant reason why the new method calculates different (generally larger) SOFs than the old. This maximum-layer approach was chosen to be consistent with the approach used in calculating ULDs for radiological assessments, and led to a change in the direction of conservatism. Differences between ESP and BBI solubilities were the next most common reason for differences between new and old SOFs, particularly in the liquid phase. The solubility-related changes in SOF were roughly equally distributed between increases and decreases. No general statement can be made about whether ESP modeling (as in the old method) or direct use of BBI data provides more accurate results; there were examples of both. Changes in the effective toxicities of TOC and lead were the third most common reason. These toxicity changes increased SOFs and so were in a conservative direction. Although decreases in $\mathrm{Ca}$ and $\mathrm{Al}$ toxicity reduced the conservatism of the new method for a few tanks, in no case did they cause the new-method SOFs to be significantly lower than those generated by the old method. 


\subsection{References}

Cowley WL, Huckaby JL, Mahoney LA, Golcar GR, Krupka KM, Sklarew DS, and DJ Geniesse. 2003. Chemical Source Terms for Tanks Farms Safety Analyses. RPP-8369, Rev. 2, CH2M HILL Hanford Group, Inc., Richland, Washington.

DOE. 2006. Revision 21 of AEGLs, ERPGs and TEELs for Chemicals of Concern (10/2005).

Subcommittee on Consequence Assessment and Protective Actions, U.S. Department of Energy; available on line at http://www.eh.doe.gov/chem_safety/teel.html

Meacham JE, Kozlowski SD, Place DE, Huckaby JL, and LA Mahoney. 2006. Tank Farms Safety Analyses Chemical Source Term Methodology. RPP-30604, Rev. 0, CH2M HILL Hanford Group, Inc., Richland, Washington.

Place DE and BA Higley. 2005. Best-Basis Inventory Process Requirements. RPP-7625, Rev. 6, CH2M HILL Hanford Group, Inc., Richland, Washington.

TWINS. 2002. BBI data downloaded from http://twinsweb.pnl.gov/data/datamenu.htm on May 12-13, 2002. 



\section{Appendix A - User-Specified Chemical Equations Used by New Method in Comparison of New and Old Methods}





\section{Appendix A \\ User-Specified Chemical Equations Used by New Method in Comparison of New and Old Methods}

This appendix lists and explains the chemical equations used to assign compounds to analytes in the new SOF calculation method. The justification of the choices of compounds is separately discussed in Appendix B.

\section{A.1 New Chemical Equations}

Table A.1 (located at the end of this appendix) contains all the chemical equations that are used for compound assignment in the new method. Several points should be noted. All the concentrations in the equations are notated in square brackets. Other entries (such as TempNa) are intermediate concentration variables. All have units of molarity. The concentrations that are never found on the left of an equals sign are the input analyte concentrations, which are based on BBI or default values. All others are compound concentrations, which are outputs.

For documentation purposes, the equations are given in a form that can be used for input to SOF Program. The intermediate concentration variables are calculated first, and the variables can refer to each other (though the references cannot be circular). The compound concentrations are calculated last, and the equation for one compound concentration cannot include a reference to any other compound concentration. Only analyte concentrations and variables can appear in the compound concentration equations.

The SOF Program software treats concentrations differently than intermediate concentration variables. The intermediate variables are allowed to take on negative values. The output (compound) concentrations are not; negative concentrations are automatically set to zero. This feature of SOF Program has required the use of workarounds in the intermediate variables, as is described in Section A.2. Workarounds have also been devised to avoid divide-by-zero errors.

The equations in Table A.1 use the same analytes that were among the ESP inputs used by Cowley et al. (2003), the major analytes and silver (Ag). Trace analyte equations are excluded in this comparison study, although they are included in the general form of the new method.

\section{A.2 Liquid-Phase Equations}

Analytes in the liquid phase fall into several categories:

1. Assigned to hydroxide compounds (e.g., $\mathrm{Al}, \mathrm{Bi}$, etc.);

2. Cations (e.g., Sr) that are charge-balanced by part of the dominant anions;

3. Assigned to compounds with analytes other than hydroxide (e.g., Ag, Ca, U);

4. Assigned to anions that form potassium and sodium salts (e.g., F);

5. Dominant anions $\left(\mathrm{NO}_{2}, \mathrm{NO}_{3}, \mathrm{OH}\right)$. 
As an example of the first category, consider the analyte Al. Its compound assignment equation is

$$
\left[\mathrm{Al}(\mathrm{OH})_{3}\right]=[\mathrm{Al}]
$$

The assignment of $\mathrm{Al}$ to $\mathrm{Al}(\mathrm{OH})_{3}$ does not affect any other analyte. The hydroxide in the compound is not free hydroxide, but bound to the metal in a hydroxide complex in solution. It therefore does not need to be subtracted from the $[\mathrm{OH}]$ concentration input to maintain a mass-balance on the $\mathrm{OH}$ analyte (which by definition is free $\mathrm{OH}$ ).

By contrast, the analytes in the second category, of which the only example is Sr, do consume hydroxide as well as other analytes. The analyte $\mathrm{Sr}$ is present in solution as an uncomplexed cation, $\mathrm{Sr}^{+2}$. Its main counterions would be the dominant anions, $\mathrm{OH}^{-}, \mathrm{NO}_{2}^{-}$, and $\mathrm{NO}_{3}{ }^{-}$. It is therefore assigned to $\operatorname{Sr}(\mathrm{OH})_{2}$, $\mathrm{Sr}\left(\mathrm{NO}_{2}\right)_{2}$, and $\mathrm{Sr}\left(\mathrm{NO}_{3}\right)_{2}$.

$$
\begin{aligned}
& {\left[\mathrm{Sr}\left(\mathrm{NO}_{2}\right)_{2}\right]=\mathrm{NO}_{2} \text { Ratio } *[\mathrm{Sr}]} \\
& {\left[\mathrm{Sr}\left(\mathrm{NO}_{3}\right)_{2}\right]=\mathrm{NO}_{3} \text { Ratio } *[\mathrm{Sr}]} \\
& {\left[\mathrm{Sr}(\mathbf{O H})_{2}\right]=\text { OHRatio } *[\mathrm{Sr}]}
\end{aligned}
$$

The amounts of these three anions that are consumed by Sr must be accounted for in the mass balances. The accounting is performed in Temp2OH, TempNO${ }_{2}$, and $\mathrm{TempNO}_{3}$ (the equations have been simplified from the form in the table to support the current explanation).

Temp2OH $=[\mathrm{OH}]-$ OHRatio* $(2 *[\mathrm{Sr}])$

TempNO $\mathrm{O}_{2}=\left[\mathrm{NO}_{2}\right]-\mathrm{NO}_{2}$ Ratio* $(2 *[\mathrm{Sr}])$

TempNO$_{3}=\left[\mathrm{NO}_{3}\right]-\mathrm{NO}_{3}$ Ratio* $(2 *[\mathrm{Sr}])$

The ratios in the equations serve the purpose of splitting $\mathrm{Sr}$ among the compounds in proportion to the relative amounts of the dominant anions.

Analytes in the third category also consume other analytes, but do not consume the dominant anions. For example, Ag tends to form chloride complexes in solution, is assigned to $\mathrm{AgCl}$, and therefore consumes $\mathrm{Cl}$ in the equations:

$$
[\mathrm{AgCl}]=[\mathrm{Ag}]
$$

All of the $\mathrm{Cl}$ that is taken up by Ag must be removed to maintain the mass balance on $\mathrm{Cl}$ (again, this equation is simplified):

$\operatorname{TempCl}=[\mathrm{Cl}]-[\mathrm{Ag}]$

The only condition under which the mass balance on $\mathrm{Cl}$ is not maintained is when [Ag] exceeds [Cl]. To prevent TempCl from being negative, the absolute-value function ABS() is used, as seen in the unsimplified version of the equation:

TempCl $=0.5 *([\mathrm{Cl}]-[\mathrm{Ag}]+\mathrm{ABS}([\mathrm{Cl}]-[\mathrm{Ag}]))$ 
This equation sets TempCl to zero if the difference ([Cl]-[Ag]) is negative; in this circumstance $\mathrm{Cl}$ is in effect "generated" to match the amount of $\mathrm{Ag}$ in solution. The analytes $\mathrm{Ca}$ and $\mathrm{Si}$, and $\mathrm{U}$ and $\mathrm{CO}_{3}$, have the same kind of relationship as $\mathrm{Ag}$ and $\mathrm{Cl}$.

Anionic analytes (other than the dominant anions) fall into the fourth category. These analytes, such as $\mathrm{F}$ and $\mathrm{Cr}(\mathrm{VI})$, are present in solution as the anions $\mathrm{F}^{-}$and $\mathrm{CrO}_{4}{ }^{-2}$, which are countered by the dominant cations, $\mathrm{Na}^{+}$and $\mathrm{K}^{+}$. The fourth-category analytes are therefore assigned to sodium and potassium salts in proportion to the relative amounts of $\mathrm{Na}$ and $\mathrm{K}$. For example, the equations for the analyte $\mathrm{F}$ are

$[\mathrm{KF}]=$ KRatio $*[\mathrm{~F}]$

$[\mathrm{NaF}]=$ NaRatio $*[\mathrm{~F}]$

The fourth-category analytes consume the analytes $\mathrm{Na}$ and $\mathrm{K}$, which is accounted for in the variables TempNa and TempK:

TempNa $=[\mathrm{Na}]-\mathrm{NaRatio} *\left(\mathrm{TempCl}+[\mathrm{TOC}]+2 * \mathrm{TempCO}_{3}+2 *[\mathrm{CrVI}]+[\mathrm{F}]+3 *\left[\mathrm{PO}_{4}\right]+2 *\left[\mathrm{SO}_{4}\right]+\right.$ $2 *$ TempSi $+[\mathrm{Pb}])$

TempK $=[\mathrm{K}]-$ KRatio $*\left(\mathrm{TempCl}+[\mathrm{TOC}]+2 * \mathrm{TempCO}_{3}+2 *[\mathrm{CrVI}]+[\mathrm{F}]+3 *\left[\mathrm{PO}_{4}\right]+2 *\left[\mathrm{SO}_{4}\right]+\right.$ $2 *$ TempSi $+[\mathrm{Pb}])$

All the fourth-category anions are included in these equations, which carry out mass-balance accounting for $[\mathrm{Na}]$ and $[\mathrm{K}]$. Some of these anions $-\mathrm{Cl}^{-}, \mathrm{CO}_{3}{ }^{-2}$, and $\mathrm{SiO}_{3}{ }^{-2}$ (representing the analyte $\mathrm{Si}$ ) - have already been partially or perhaps completely consumed by category-three analytes. Only the remaining portions of these anions (which may be zero) are assigned to sodium and potassium salts.

Note that TempCl, for example, is used as a term in the equations (to represent the portion of the $\mathrm{Cl}$ that is assigned to $\mathrm{NaCl}$ and $\mathrm{KCl}$ ) instead of using the difference expression $([\mathrm{Cl}]-[\mathrm{Ag}])$. The two expressions are not equivalent. TempCl can only be zero or positive. The difference ([Cl] - $[\mathrm{Ag}])$ can be zero, positive, or negative. Of the two expressions, TempCl is the one that is required in the mass balance in order to maintain consistency with the $\mathrm{NaCl}$ and $\mathrm{KCl}$ equations. Using it ensures that $[\mathrm{NaCl}]$ and $[\mathrm{KCl}]$ are zeroed whenever $[\mathrm{Ag}]$ exceeds [Cl].

The only analytes in the fifth category, dominant anions, are $\mathrm{OH}$ (free $\mathrm{OH}$ ), $\mathrm{NO}_{2}$, and $\mathrm{NO}_{3}$. These anions are treated as being counter-balanced by $\mathrm{Na}$ and $\mathrm{K}$. They are split between $\mathrm{Na}$ and $\mathrm{K}$ in proportion to the relative amounts of the $\mathrm{Na}$ and $\mathrm{K}$ that are left over after all the other anions have been accounted for.

In summary, the liquid-phase compound assignment process in the new method begins by assigning compounds to analytes in the first three categories. Then the fourth-category anions (including the $\mathrm{Cl}$, $\mathrm{CO}_{3}$, and $\mathrm{Si}$ already partially consumed by $\mathrm{Ag}$, $\mathrm{U}$, and $\mathrm{Ca}$ ) are assigned to sodium and potassium salts. Finally the dominant anions (free $\mathrm{OH}^{-}, \mathrm{NO}_{2}^{-}$, and $\mathrm{NO}_{3}{ }^{-}$) are split among $\mathrm{Na}$ and $\mathrm{K}$.

Most of the liquid-phase chemical equations in Table B.1 carry out compound assignments, as just described. A few, however, carry out operations that are intended to avoid divide-by-zero errors in the calculation of ratios. 
It is possible, in very dilute waste liquids, for $[\mathrm{Na}]$ and $[\mathrm{K}]$ both to be zero, in which case NaRatio and KRatio incur a divide-by-zero error. The variable TempXNa is used to avoid this:

$\boldsymbol{T e m p X N a}=0.000000001+0.5 *([\mathrm{Na}]+\mathrm{ABS}([\mathrm{Na}]))$

TempXNa will be given a value only negligibly different from [Na], so long as [Na] is non-zero. If [Na] is zero, TempXNa is given a value of $1 \mathrm{E}-09$. This variable is used only in calculating NaRatio and KRatio:

NaRatio $=$ TempXNa $/([\mathrm{K}]+$ TempXNa $)$

KRatio = 1 - NaRatio

If $[\mathrm{Na}]$ is not zero, TempXNa is insignificant and NaRatio is $[\mathrm{Na}] /([\mathrm{K}]+[\mathrm{Na}])$. If $[\mathrm{Na}]$ is zero and $[\mathrm{K}]$ is non-zero, NaRatio will be essentially equal to $1 \mathrm{E}-09 /[\mathrm{K}]$ and KRatio will be very close to unity. And if both $[\mathrm{Na}]$ and $[\mathrm{K}]$ equal zero, NaRatio is unity and KRatio is zero; all the anions are treated as forming sodium salts.

The variables TempXNO3, Temp2Na, and Temp2K provide the same type of protection against divideby-zero errors in $\mathrm{NO}_{2}$ Ratio, $\mathrm{NO}_{3}$ Ratio, OHRatio and the final calculation of [ $\left.\mathrm{NaNO}_{3}\right]$, [ $\left.\mathrm{NaNO}_{2}\right],[\mathrm{NaOH}$, $\left[\mathrm{KNO}_{3}\right]$, $\left[\mathrm{KNO}_{2}\right]$, and $[\mathrm{KOH}]$.

\section{A.3 Wet Bulk Solids Equations}

The new-method chemical equations for the wet bulk solids phase are simpler than those for the liquid phase. Because potassium is not a major contributor to the dry solids, all the anionic analytes are treated as sodium salts (except that $\mathrm{K}$ is assigned to $\mathrm{KNO}_{3}$ ). This approach eliminates the $\mathrm{Na} / \mathrm{K}$ salt split carried out by ratios in the liquid phase. No divide-by-zero protections are needed.

In the wet bulk solids phase, several analytes are assigned in a manner that consumes other analytes, just as $\mathrm{Ag}$ consumed $\mathrm{Cl}$ in the liquid phase:

- Ag is assigned to $\mathrm{Ag}_{2} \mathrm{CO}_{3}$, consuming $\mathrm{CO}_{3}$;

- $\mathrm{Ca}$ is assigned to $\mathrm{Ca}_{5} \mathrm{OH}\left(\mathrm{PO}_{4}\right)_{3}$, consuming $\mathrm{PO}_{4}$ (the $\mathrm{OH}$ is not derived from free $\mathrm{OH}$ );

- $\mathrm{K}$ is assigned to $\mathrm{KNO}_{3}$, consuming $\mathrm{NO}_{3}$;

- $\mathrm{La}$ is assigned to $\mathrm{LaPO}_{4}$, consuming $\mathrm{PO}_{4}$;

- $\mathrm{Si}$ is assigned to $\mathrm{NaAlSiO}_{4}$, consuming $\mathrm{Al}$; and

- $\mathrm{Sr}$ is assigned to $\mathrm{SrCO}_{3}$, consuming $\mathrm{CO}_{3}$.

The mass-balances on the consumed analytes are carried out as for the liquid phase. It is possible (as in the liquid) for the consumed analytes to have a higher concentration in the final mixture of compounds than in the BBI-based inputs. For example, if [Si] exceeds [Al], then enough $\mathrm{NaAlSiO}_{4}$ will be formed to represent all the $\mathrm{Si}$, which will over-represent the $\mathrm{Al}$. As a result, the concentration $\left[\mathrm{Al}(\mathrm{OH})_{3}\right]$ will equal zero because SOF Program will set the negative difference ([Al] - [Si]) to zero. 
Table A.1. Basis for Calculating Compounds of Major Analytes in the New SOF Calculation Method

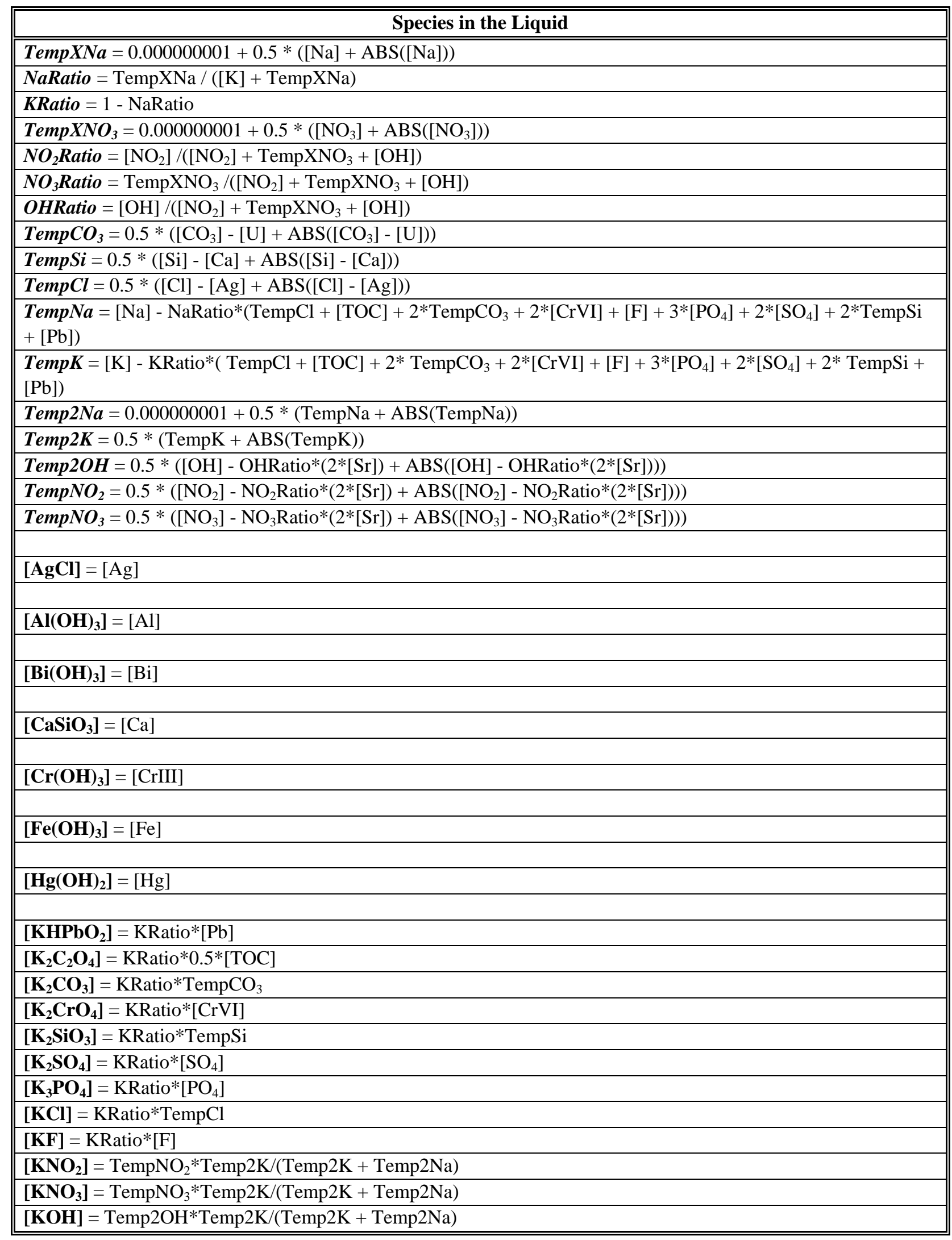


Table A.1. (contd.)

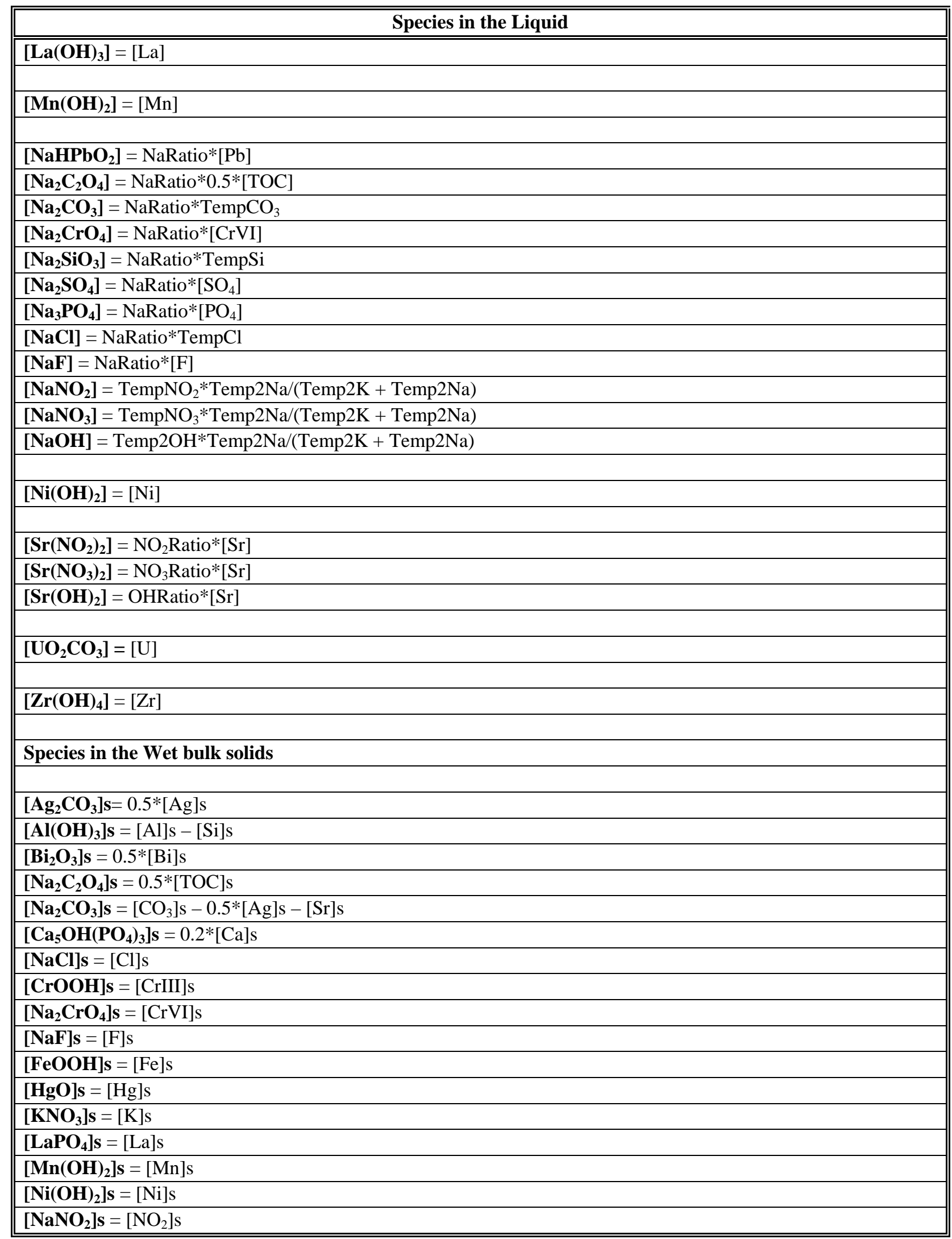


Table A.1. (contd.)

\begin{tabular}{|c|}
\hline Species in the Liquid \\
\hline$\left[\mathrm{NaNO}_{3}\right] \mathbf{s}=\left[\mathrm{NO}_{3}\right] \mathrm{s}-[\mathrm{K}] \mathrm{s}$ \\
\hline$[\mathrm{NaOH}] \mathrm{s}=[\mathrm{OH}] \mathrm{s}$ \\
\hline$\left[\mathrm{Na}_{3} \mathbf{P O}_{4}\right] \mathbf{s}=\left[\mathrm{PO}_{4}\right] \mathrm{s}-0.6 *[\mathrm{Ca}] \mathrm{s}-[\mathrm{La}] \mathrm{s}$ \\
\hline$\left[\mathbf{P b}(\mathbf{O H})_{2}\right] \mathbf{s}=[\mathrm{Pb}] \mathrm{s}$ \\
\hline$\left[\mathrm{Na}_{2} \mathrm{SO}_{4}\right] \mathbf{s}=\left[\mathrm{SO}_{4}\right] \mathrm{s}$ \\
\hline$\left[\mathrm{NaAlSiO}_{4}\right] \mathrm{s}=[\mathrm{Si}] \mathrm{s}$ \\
\hline$\left[\mathrm{SrCO}_{3}\right] \mathbf{s}=[\mathrm{Sr}] \mathrm{s}$ \\
\hline$\left[\mathrm{Na}_{2} \mathrm{U}_{2} \mathbf{O}_{7}\right] \mathbf{s}=0.5 *[\mathrm{U}] \mathrm{s}$ \\
\hline$\left[\mathrm{ZrO}_{2}\right] \mathrm{s}=[\mathrm{Zr}] \mathrm{s}$ \\
\hline
\end{tabular}





\section{Appendix B - Basis for Assignment of Major Compounds}

in the New SOF Calculation Method 



\section{Appendix B - Basis for Assignment of Major Compounds in the New SOF Calculation Method}

Compared to the old method, the one used for and described by Cowley et al. (2003), the new method of SOF calculation relies on a smaller and less tank-specific set of chemical compounds to represent each of the analytes in the Best Basis Inventory. In the old method, the ESP chemical thermodynamic model was used to predict the compounds in which each analyte would be present in each tank, based on the overall chemical composition of that tank's waste. The ESP output was post-processed, using the chemical equations in Tables C.3 and C.4 of the study done by Cowley et al., to convert ionic complexes, double salts, and hydrates (for example) to neutral compounds for which TEELs were available, that information being requisite to SOF calculation.

The new method uses a smaller set of chemical equations (Appendix A of this report) to convert the BBI analytes directly to compounds. Table A.1 expresses all concentrations (items in square brackets) and variables (such as TempNa) in units of molarity. Boldface items are either output compound concentrations or intermediate (placeholder) concentration variables. The concentrations that are not in boldface are the input analyte concentrations.

The net effect of the change in assignment of compounds is to make the overall toxicity of any given analyte different from its value under the old method. Generally speaking, ESP-predicted prevalence in the Hanford wastes was the main consideration in choosing the simplified set of compounds; chemical plausibility and reasonable toxicological conservatism were also considered. Complete toxicological conservatism - the use of the maximum toxicity at each TEEL level - was considered undesirable as being unrealistically conservative. On occasion there were trade-offs between the various considerations, so some engineering judgment was required to make the choices of compounds.

The purpose of this appendix is to justify the choices of compounds. Most of the attention is directed to the metals (other than sodium and potassium) and their compounds. The metals each have a wide range of possible counter-ions; they could hypothetically appear as oxides, hydroxides, oxyhydroxides, chlorides, sulfates, carbonates, with these compounds potentially having different toxicities, so that ESP modeling results for complexing and precipitation must be considered to justify which compound is chosen. The compounds used to represent the anions $\left(\mathrm{Cl}^{-}, \mathrm{F}^{-}, \mathrm{NO}_{2}{ }^{-}, \mathrm{NO}_{3}^{-}\right.$, free $\mathrm{OH}^{-}, \mathrm{CO}_{3}{ }^{-2}, \mathrm{PO}_{4}{ }^{-3}, \mathrm{SO}_{4}{ }^{-2}$, and TOC anions) require less justification. The only significant counter-ions for the anions are sodium and potassium. For this reason, the assignment of anions to sodium and potassium salts is not discussed in detail, unlike the assignment of metal compounds.

Table B.1, which gives the information pertinent to silver, is an example of the systematic approach that was used to assign compounds to metals. On the left, the table lists the moles of the silver-containing neutral compounds and ionic complexes that ESP predicted to exist in all 177 tanks, based on the May 2002 BBI. On the right, the table lists the values of TEEL-1, -2 , and -3 for the same compounds. The TEELs are expressed not in the conventional units of $\mathrm{mg}$ compound $/ \mathrm{m}^{3}$, but as $\mathrm{mmol} \mathrm{Ag} / \mathrm{m}^{3}$. (Lower TEELs indicate greater toxicity.) These units allow comparison of Ag-containing species in terms of the toxicity that is attributed to Ag. Charged complexes by definition do not have TEELs, and there are a few compounds for which TEELs were not obtained. In some cases, such as the nitrite, the toxicity may derive more from the anion than from the silver; however, for the purpose of compound assignment only the silver is considered. 
The remainder of this appendix discusses the rationale for compound selection on an analyte-by-analyte basis.

\section{B.1 Silver (Ag)}

In the new method, silver is defined as $\mathrm{AgCl}$ in the liquid phase. In the wet bulk solid phase, silver is assigned to silver carbonate, $\mathrm{Ag}_{2} \mathrm{CO}_{3}$. The chemical equations that make these assignments can be seen in Table A.1. Table B.1 shows the information relevant to the assignment of compounds.

The predominant form of Ag in solution was silver chloride complexes, with silver hydroxide complexes coming a distant second. In the wet bulk solid the prevalent compound was silver carbonate. The assignment of $\mathrm{Ag}$ to $\mathrm{AgCl}$ means that, in cases where the molar concentration of $\mathrm{Ag}$ exceeds that of $\mathrm{Cl}$, chloride in excess of that given by the BBI will be "generated" to fill out the AgCl. In addition, because all the chloride is taken up by $\mathrm{AgCl}$, none will be left over to form liquid-phase $\mathrm{NaCl}$. This effect is unavoidable if liquid-phase Ag is to be appropriately represented. Similar statements can be made for carbonate in the solid phase because of the assignment of solid-phase $\mathrm{Ag}$ to $\mathrm{Ag}_{2} \mathrm{CO}_{3}$.

Table B.1. Prevalence and Toxicity of Silver Compounds

\begin{tabular}{||l|c|c||}
\hline \multirow{3}{||}{ Analyte: Silver } & \multicolumn{2}{c|}{$\begin{array}{c}\text { Total over all tanks, 2002 } \\
\text { ESP Prediction }\end{array}$} \\
\cline { 2 - 3 } & $\begin{array}{c}\text { Moles analyte } \\
\text { in liquid in } \\
\text { this form }\end{array}$ & $\begin{array}{c}\text { Moles analyte } \\
\text { in dry solid in } \\
\text { this form }\end{array}$ \\
\hline \hline Silver carbonate & 0 & $3.62 \mathrm{E}+04$ \\
\hline Silver chloride and complexes & $2.28 \mathrm{E}+04$ & 0 \\
\hline Silver hydroxide and & $8.92 \mathrm{E}+02$ & 0 \\
\hline Complexes & $4.21 \mathrm{E}-03$ & 0 \\
\hline Silver nitrate & $7.42 \mathrm{E}+01$ & 0 \\
\hline Silver nitrite and complexes & 0 & 0 \\
\hline Potassium argentate & 0 & 0 \\
\hline Sodium argentate & $1.12 \mathrm{E}-02$ & 0 \\
\hline Ag & $1.34 \mathrm{E}-03$ & 0 \\
\hline Ag acetate and complexes & $1.69 \mathrm{E}-02$ & 0 \\
\hline Ag oxalate and complexes & $1.01 \mathrm{E}-03$ & 0 \\
\hline Ag fluoride and complexes & $1.88 \mathrm{E}-03$ & 0 \\
\hline Ag sulfate and complexes & & \\
\hline
\end{tabular}

\begin{tabular}{||c|c|c||}
\hline \multicolumn{3}{||}{ TEELs expressed in $\mathbf{~ m m o l ~ a n a l y t e / \mathbf { m } ^ { 3 }}$} \\
\hline & & \\
TEEL-1 & TEEL-2 & TEEL-3 \\
\hline \hline 0.00029 & 0.00044 & 0.091 \\
\hline 0.00028 & 0.00042 & 0.087 \\
\hline 0.00028 & 0.00048 & 0.080 \\
\hline 0.00026 & 0.00044 & 0.088 \\
\hline 0.00026 & 0.00039 & 0.081 \\
\hline 0.00028 & 0.00041 & 0.083 \\
\hline 0.00024 & 0.00045 & 0.091 \\
\hline \multicolumn{3}{|}{} \\
\hline
\end{tabular}

\section{B.2 Aluminum (Al)}

The new method defines aluminum as being present only as $\mathrm{Al}(\mathrm{OH})_{3}$ in the liquid phase and primarily as $\mathrm{Al}(\mathrm{OH})_{3}$ in the wet bulk solid phase. Some aluminum may also be present as sodium aluminosilicate, $\mathrm{NaAlSiO}_{4}$, if silicon (Si) is present in the solids. The basis for this assignment of compounds can be seen in Table B.2. 
The overwhelmingly predominant form of $\mathrm{Al}$ in solution was the $\mathrm{Al}(\mathrm{OH})_{4}{ }^{-}$ionic complex, which is considered to be toxicologically equivalent to $\mathrm{Al}(\mathrm{OH})_{3}$. This equivalence is consistent with the assumptions made in the old method.

Table B.2. Prevalence and Toxicity of Aluminum Compounds

\begin{tabular}{||l|c|c||}
\hline \multirow{2}{*}{\multicolumn{1}{||}{ Analyte: Aluminum }} & \multicolumn{2}{c||}{$\begin{array}{c}\text { Total over all tanks, 2002 } \\
\text { ESP Prediction }\end{array}$} \\
\cline { 2 - 3 } & $\begin{array}{c}\text { Moles analyte } \\
\text { in liquid in } \\
\text { this form }\end{array}$ & $\begin{array}{c}\text { Moles analyte } \\
\text { in dry solid in } \\
\text { this form }\end{array}$ \\
\hline \hline $\begin{array}{l}\text { Aluminum hydroxide and most } \mathrm{OH} \\
\text { Complexes }\end{array}$ & $5.11 \mathrm{E}-01$ & $1.85 \mathrm{E}+08$ \\
\hline Aluminum nitrite & 0 & 0 \\
\hline Aluminum nitrate & 0 & 0 \\
\hline Sodium aluminate & 0 & $1.26 \mathrm{E}+05$ \\
\hline Monopotassium aluminum hydroxide & 0 & 0 \\
\hline Potassium aluminate & 0 & 0 \\
\hline Potassium alumino-silicate & 0 & $4.90 \mathrm{E}+05$ \\
\hline Sodium aluminosilicate & 0 & $2.00 \mathrm{E}+07$ \\
\hline $\begin{array}{l}\text { Sodium aluminum carbonate } \\
\text { dihydroxide }\end{array}$ & 0 & $1.39 \mathrm{E}+07$ \\
\hline $\mathrm{Al}^{+3}$ & $2.44 \mathrm{E}-13$ & 0 \\
\hline $\mathrm{Al}(\mathrm{OH})_{4}^{-}$ & $8.11 \mathrm{E}+07$ & 0 \\
\hline $\mathrm{Al}$ fluoride and complexes & $8.38 \mathrm{E}+02$ & 0 \\
\hline $\mathrm{Al}$ acetate and complexes & $4.02 \mathrm{E}-14$ & 0 \\
\hline Al sulfate and complexes & $2.25 \mathrm{E}-12$ & 0 \\
\hline \hline
\end{tabular}

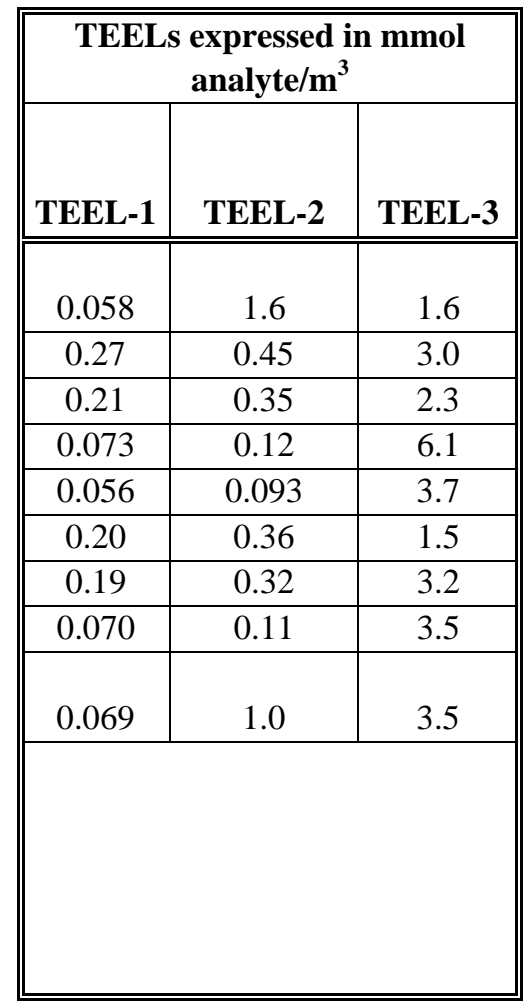

Aluminum hydroxide, $\mathrm{Al}(\mathrm{OH})_{3}$, also predominated in the dry solid phase in the predicted total inventory of 2002. However, there were competing forms of aluminum solids. The major competitor was $\mathrm{NaAlSiO}_{4}$, a compound whose toxicity could be assigned to either Al or Si. In the new model all wetsolid-phase $\mathrm{Si}$ is assigned to the aluminosilicate; an amount of $\mathrm{Al}$ that is equal to the $\mathrm{Si}$ is also assigned to $\mathrm{NaAlSiO}_{4}$, and any $\mathrm{Al}$ in excess of that is assigned to $\mathrm{Al}(\mathrm{OH})_{3}$ in the solids. In tanks where the Si concentration exceeds the $\mathrm{Al}$, this approach will produce an $\mathrm{Al}$ concentration in the solids that exceeds the BBI value, in effect "generating" $\mathrm{Al}$, and will assign all Al to the aluminosilicate and none to aluminum hydroxide. These effects are unavoidable if $\mathrm{Si}$ is to be represented in a reasonably conservative way.

\section{B.3 Bismuth (Bi)}

The new method defines bismuth as being present only as $\mathrm{Bi}(\mathrm{OH})_{3}$ in the liquid phase and only as $\mathrm{Bi}_{2} \mathrm{O}_{3}$ in the wet bulk solid phase. Table B.3 shows that these assignments are in accord with the predominant species in the liquid and dry solid phases, as predicted by the ESP model for all 177 tanks in May 2002. 
Table B.3. Prevalence and Toxicity of Bismuth Compounds

\begin{tabular}{|c|c|c|}
\hline \multirow[b]{2}{*}{ Analyte: Bismuth } & \multicolumn{2}{|c|}{$\begin{array}{c}\text { Total over all tanks, } 2002 \text { ESP } \\
\text { Prediction }\end{array}$} \\
\hline & $\begin{array}{l}\text { Moles analyte } \\
\text { in liquid in } \\
\text { this form }\end{array}$ & $\begin{array}{l}\text { Moles analyte } \\
\text { in dry solid in } \\
\text { this form }\end{array}$ \\
\hline Bismuth hydroxide and complexes & $1.83 \mathrm{E}+04$ & 0 \\
\hline Bismuth nitrate and complexes & 1.34E-14 & 0 \\
\hline Bismuth oxychloride & 0 & $2.44 \mathrm{E}+05$ \\
\hline Bismuth sesquioxide & 0 & $2.44 \mathrm{E}+06$ \\
\hline Monopotassium bismuth hydroxide & 0 & 0 \\
\hline Monosodium bismuth hydroxide & 0 & 0 \\
\hline $\mathrm{Bi}^{+3}$ & $1.19 \mathrm{E}-16$ & 0 \\
\hline Bi acetate and complexes & $3.55 \mathrm{E}-18$ & 0 \\
\hline Bi chloride and complexes & 7.17E-15 & 0 \\
\hline
\end{tabular}

\begin{tabular}{|c|c|c|}
\hline \multicolumn{3}{|c|}{$\begin{array}{c}\text { TEELs expressed in mmol } \\
\text { analyte } / \mathrm{m}^{3}\end{array}$} \\
\hline TEEL-1 & TEEL-2 & TEEL-3 \\
\hline 0.0038 & 0.012 & 0.38 \\
\hline 0.010 & 0.063 & 1.3 \\
\hline 0.96 & 1.9 & 1.9 \\
\hline 0.26 & 1.7 & 2.1 \\
\hline 0.013 & 0.079 & 0.63 \\
\hline 0.017 & 0.12 & 0.50 \\
\hline
\end{tabular}

\section{B.4 Calcium (Ca)}

In the new method, calcium is defined as calcium metasilicate, $\mathrm{CaSiO}_{3}$, in the liquid phase. In the wet bulk solid phase calcium is assigned to calcium hydroxyapatite, $\mathrm{Ca}_{5} \mathrm{OH}\left(\mathrm{PO}_{4}\right)_{3}$. Table $\mathrm{B} .4$ shows the available information.

Table B.4. Prevalence and Toxicity of Calcium Compounds

\begin{tabular}{||l|c|c||}
\hline \multicolumn{1}{|c|}{ Analyte: Calcium } & \multicolumn{2}{c|}{$\begin{array}{c}\text { Total over all tanks, 2002 ESP } \\
\text { Prediction }\end{array}$} \\
\cline { 2 - 3 } & $\begin{array}{c}\text { Moles analyte } \\
\text { in liquid in } \\
\text { this form }\end{array}$ & $\begin{array}{c}\text { Moles analyte } \\
\text { in dry solid in } \\
\text { this form }\end{array}$ \\
\hline \hline Calcium carbonate and complexes & $3.58 \mathrm{E}+01$ & $2.50 \mathrm{E}+05$ \\
\hline Calcium fluoride and complexes & $1.10 \mathrm{E}-02$ & $8.21 \mathrm{E}+05$ \\
\hline Calcium hydroxide and complexes & $5.79 \mathrm{E}+01$ & $3.91 \mathrm{E}+04$ \\
\hline Calcium hydroxyapatite & 0 & $5.17 \mathrm{E}+06$ \\
\hline Calcium metasilicate & 0 & 0 \\
\hline Calcium oxide & 0 & 0 \\
\hline Calcium phosphate and complexes & $4.51 \mathrm{E}+02$ & 0 \\
\hline Calcium sulfate and complexes & $9.83 \mathrm{E}+00$ & 0 \\
\hline Calcium nitrate and complexes & $1.10 \mathrm{E}+02$ & 0 \\
\hline Calcium nitrite and complexes & 0 & 0 \\
\hline Calcium oxalate and complexes & $2.55 \mathrm{E}+00$ & $2.38 \mathrm{E}+03$ \\
\hline Ca ${ }^{+2}$ & $8.79 \mathrm{E}+02$ & 0 \\
\hline Calcium hydrogen metasilicate ion & $1.76 \mathrm{E}+02$ & 0 \\
\hline Calcium dihydrogen silicate & $3.59 \mathrm{E}+03$ & 0 \\
\hline Ca acetate and complexes & $9.62 \mathrm{E}+00$ & 0 \\
\hline
\end{tabular}

\begin{tabular}{||c|c|c||}
\hline \hline \multicolumn{2}{||c|}{$\begin{array}{c}\text { Rev. 21A TEELs expressed in } \\
\text { mmol analyte/m }\end{array}$} \\
\hline & & \\
TEEL-1 & TEEL-2 & TEEL-3 \\
\hline \hline 0.15 & 0.15 & 0.15 \\
\hline 0.19 & 0.32 & 6.4 \\
\hline 0.20 & 0.34 & 6.7 \\
\hline 0.35 & 0.60 & 5.0 \\
\hline 0.26 & 0.43 & 2.2 \\
\hline 0.089 & 0.089 & 0.45 \\
\hline 0.19 & 0.34 & 3.4 \\
\hline 0.22 & 0.37 & 1.8 \\
\hline 0.021 & 0.15 & 0.76 \\
\hline 0.00057 & 0.0045 & 0.38 \\
\hline 0.12 & 0.39 & 0.39 \\
\hline \multicolumn{3}{|l}{} \\
& & \\
& & \\
\hline
\end{tabular}


The predominant form of $\mathrm{Ca}$ in solution was calcium dihydrogen silicate, for which there is no TEEL. There is, however, a TEEL for a closely related compound, calcium metasilicate. This compound is used to represent calcium in the liquid phase. The assignment of $\mathrm{Ca}$ to $\mathrm{CaSiO}_{3}$ means that, in cases where the molar concentration of $\mathrm{Ca}$ exceeds that of $\mathrm{Si}$, silicon in excess of that given by the BBI will be "generated" to fill out the $\mathrm{CaSiO}_{3}$. In addition, because all the silicon is taken up by $\mathrm{CaSiO}_{3}$, none will be left over to form liquid-phase sodium and potassium metasilicates. This effect is unavoidable if liquidphase Ca is to be appropriately represented.

$\mathrm{Ca}_{5} \mathrm{OH}\left(\mathrm{PO}_{4}\right)_{3}$ predominated by about a factor of 5 in the dry solid phase in the predicted total inventory of 2002. It was therefore assigned to $\mathrm{Ca}$ as the solid-phase compound. It does not conservatively represent the toxicity of all the solid-phase Ca compounds, which on the average are a factor of 2 more toxic. However, because it is predicted to be about 5 times more prevalent, the assumption that all $\mathrm{Ca}$ is $\mathrm{Ca}_{5} \mathrm{OH}\left(\mathrm{PO}_{4}\right)_{3}$ is considered reasonably conservative.

\section{B.5 Chloride (Cl)}

In the new method, as in the old, chloride was split between $\mathrm{NaCl}$ and $\mathrm{KCl}$ in the liquid and was assigned to $\mathrm{NaCl}$ in the solid (Table A.1). The liquid-phase chloride that was included in silver chloride (Section B.1) was not part of that which was split between $\mathrm{NaCl}$ and $\mathrm{KCl}$. In a tank where dissolved Ag exceeds dissolved $\mathrm{Cl}$, the method would indicate that there was no $\mathrm{NaCl}$ or $\mathrm{KCl}$ and would produce $\mathrm{Cl}$ concentrations greater than the BBI value. This effect is unavoidable if liquid-phase Ag is to be appropriately represented.

\section{B.6 Chromium (Cr)}

The new method assigns $\mathrm{Cr}(\mathrm{III})$ to $\mathrm{Cr}(\mathrm{OH})_{3}$ in the liquid and to chromium oxyhydroxide (CrOOH) in the wet bulk solid. As shown in Table B.5a, the basis for the assignment of Cr(III) compounds was prevalence in the ESP-predicted 177-tank inventory.

Table B.5a. Prevalence and Toxicity of Chromium (III) Compounds

\begin{tabular}{|c|c|c|c|c|c|}
\hline \multirow[b]{2}{*}{ Analyte: Chromium (III) } & \multicolumn{2}{|c|}{$\begin{array}{c}\text { Total over all tanks, } 2002 \\
\text { ESP Prediction }\end{array}$} & \multicolumn{3}{|c|}{$\begin{array}{l}\text { TEELs expressed in } \\
\text { mmol analyte/m } \mathbf{m}^{3}\end{array}$} \\
\hline & \begin{tabular}{|c|}
$\begin{array}{c}\text { Moles analyte } \\
\text { in liquid in } \\
\text { this form }\end{array}$ \\
\end{tabular} & \begin{tabular}{|c|}
$\begin{array}{c}\text { Moles analyte } \\
\text { in dry solid in } \\
\text { this form }\end{array}$ \\
\end{tabular} & TEEL-1 & TEEL-2 & TEEL-3 \\
\hline Chromic oxide $\mathrm{Cr}_{2} \mathrm{O}_{3}$ & 0 & 0 & 0.030 & 0.049 & 0.46 \\
\hline Chromium III hydroxide and complexes & 3.84E-04 & 0 & 0.015 & 0.049 & 0.49 \\
\hline Chromium oxyhydroxide & 0 & $8.14 \mathrm{E}+06$ & 0.012 & 0.044 & 0.47 \\
\hline Chromium(III) nitrate and complexes & $3.11 \mathrm{E}-15$ & 0 & 0.025 & 0.042 & 0.42 \\
\hline $\mathrm{Cr}^{+3}$ & 4.83E-17 & 0 & & & \\
\hline Cr fluoride and complexes & 7.09E-11 & 0 & & & \\
\hline Cr chloride and complexes & $5.38 \mathrm{E}-18$ & 0 & & & \\
\hline Cr phosphate and complexes & 3.80E-09 & 0 & & & \\
\hline Cr sulfate and complexes & $3.29 \mathrm{E}-13$ & 0 & & & \\
\hline
\end{tabular}


In the new method, as in the old, $\mathrm{Cr}(\mathrm{VI})$ in the liquid was assigned to $\mathrm{Na}_{2} \mathrm{CrO}_{4}$ and $\mathrm{K}_{2} \mathrm{CrO}_{4}$. All $\mathrm{Cr}(\mathrm{VI})$ in the wet bulk solid phase is assigned to sodium chromate, $\mathrm{Na}_{2} \mathrm{CrO}_{4}$. Table B.5b shows the basis for this choice; chromium (VI) hydroxide and dichromate ion are negligible in Hanford tank waste, according to the 2002 ESP predictions.

Table B.5b. Prevalence and Toxicity of Chromium (VI) Compounds

\begin{tabular}{||l|c|c||}
\hline \multicolumn{1}{||}{} & \multicolumn{2}{|c|}{$\begin{array}{c}\text { Total over all tanks, 2002 } \\
\text { ESP Prediction }\end{array}$} \\
\cline { 2 - 3 } & $\begin{array}{c}\text { Moles analyte } \\
\text { in liquid in } \\
\text { this form }\end{array}$ & $\begin{array}{l}\text { Moles analyte } \\
\text { in dry solid in } \\
\text { this form }\end{array}$ \\
\hline Chalyte: Chromium (VI) & 0 & 0 \\
\hline Chromium(VI) hydroxide & 0 & 0 \\
\hline Potassium chromate & 0 & 0 \\
\hline Crite chromate(VI) & 0 & 0 \\
\hline $\begin{array}{l}\text { Chromate ion } \mathrm{CrO}_{4}^{-2} \text { and hydrogen } \\
\text { chromate ion }\end{array}$ & $4.04 \mathrm{E}+06$ & 0 \\
\hline Dichromate ion $\mathrm{Cr}_{2} \mathrm{O}_{7}^{-2}$ & $1.34 \mathrm{E}-02$ & 0 \\
\hline
\end{tabular}

\begin{tabular}{|c|c|c|}
\hline \multicolumn{3}{|c|}{$\begin{array}{l}\text { Rev. 21A TEELs expressed in } \\
\text { mmol analyte } / \mathrm{m}^{3}\end{array}$} \\
\hline TEEL-1 & TEEL-2 & TEEL-3 \\
\hline 0.00019 & 0.00065 & 0.097 \\
\hline 0.0019 & 0.0019 & 0.25 \\
\hline 0.0018 & 0.018 & 0.26 \\
\hline
\end{tabular}

\section{B.7 Fluoride (F)}

In the new method, fluoride was split between $\mathrm{NaF}$ and $\mathrm{KF}$ in the liquid and was assigned to $\mathrm{NaF}$ in the wet bulk solid (Table A.1). This was essentially the same approach as was used in the old method. The fluoride double salts predicted by the ESP model were split into single salts for the purpose of toxicological assessment; that separation, in effect, assigned all solid fluoride to $\mathrm{NaF}$.

\section{B.8 Iron (Fe)}

The new method assigns iron to $\mathrm{Fe}(\mathrm{OH})_{3}$ in the liquid and goethite $(\mathrm{FeOOH})$ in the wet bulk solid. As shown in Table B.6, the basis for the assignment of Fe compounds was prevalence in the ESP-predicted 177-tank inventory.

Table B.6. Prevalence and Toxicity of Iron Compounds

\begin{tabular}{||l|c|c||}
\hline \multirow{2}{*}{\multicolumn{1}{|c|}{ Analyte: Iron }} & \multicolumn{2}{c|}{$\begin{array}{c}\text { Total over all tanks, 2002 ESP } \\
\text { Prediction }\end{array}$} \\
\cline { 2 - 3 } & $\begin{array}{c}\text { Moles analyte } \\
\text { in liquid in } \\
\text { this form }\end{array}$ & $\begin{array}{c}\text { Moles analyte } \\
\text { in dry solid in } \\
\text { this form }\end{array}$ \\
\hline FeOOH (goethite) & 0 & $2.35 \mathrm{E}+07$ \\
\hline Iron III hydroxide (and complexes) & $1.72 \mathrm{E}+02$ & 0 \\
\hline Ferric oxide & 0 & 0 \\
\hline Fe ${ }^{+3}$ & $3.79 \mathrm{E}-19$ & 0 \\
\hline Fe oxalate and complexes & $3.88 \mathrm{E}-06$ & 0 \\
\hline Fe chloride and complexes & $7.97 \mathrm{E}-22$ & 0 \\
\hline Fe fluoride and complexes & $1.65 \mathrm{E}-15$ & 0 \\
\hline Fe phosphate and complexes & $8.26 \mathrm{E}-14$ & 0 \\
\hline Fe nitrate and complexes & $6.74 \mathrm{E}-21$ & 0 \\
\hline Fe sulfate and complexes & $3.69 \mathrm{E}-20$ & 0 \\
\hline
\end{tabular}

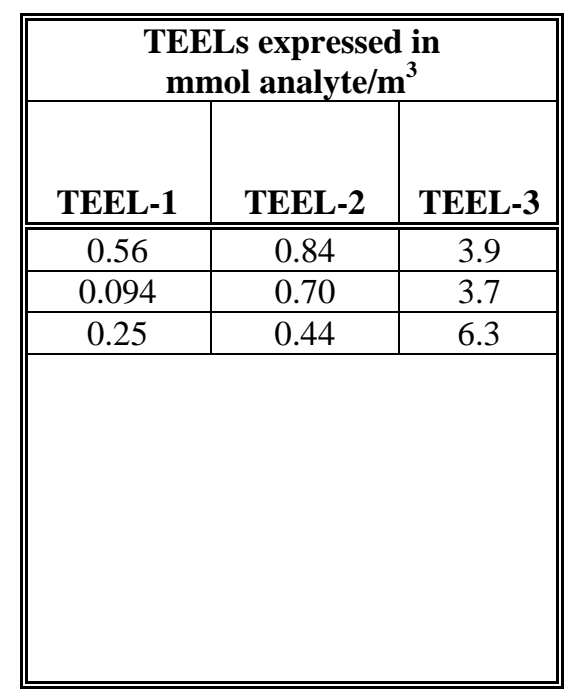




\section{B.9 Mercury (Hg)}

The new method assigns mercury to $\mathrm{Hg}(\mathrm{OH})_{2}$ in the liquid and to mercuric oxide (HgO) in the wet bulk solid. As shown in Table B.7, the basis for the assignment of $\mathrm{Hg}$ compounds is consistent with prevalence.

Table B.7. Prevalence and Toxicity of Mercury Compounds

\begin{tabular}{||l|c|c||}
\hline \multirow{2}{*}{\multicolumn{1}{||}{ Analyte: Mercury }} & \multicolumn{2}{|c||}{$\begin{array}{c}\text { Total over all tanks, 2002 ESP } \\
\text { Prediction }\end{array}$} \\
\cline { 2 - 3 } & $\begin{array}{c}\text { Moles analyte } \\
\text { in liquid in this } \\
\text { form }\end{array}$ & $\begin{array}{c}\text { Moles analyte } \\
\text { in dry solid in } \\
\text { this form }\end{array}$ \\
\hline \hline Mercury hydroxide (and complexes) & $4.17 \mathrm{E}+03$ & 0 \\
\hline Mercury nitrate & 0 & 0 \\
\hline Mercury nitrite & 0 & 0 \\
\hline Mercury(II) chloride (and complexes) & $1.58 \mathrm{E}+01$ & 0 \\
\hline Mercury(II) oxide & 0 & $5.45 \mathrm{E}+03$ \\
\hline Hg ${ }^{+2}$ & $2.75 \mathrm{E}-09$ & 0 \\
\hline Hg acetate and complexes & $2.11 \mathrm{E}-06$ & 0 \\
\hline Hg oxalate and complexes & $3.16 \mathrm{E}-03$ & 0 \\
\hline Hg fluoride and complexes & $1.86 \mathrm{E}-10$ & 0 \\
\hline
\end{tabular}

\begin{tabular}{|c|c|c|}
\hline \multicolumn{3}{|c|}{$\begin{array}{l}\text { TEELs expressed in } \\
\text { mmol analyte/ } \mathbf{m}^{3}\end{array}$} \\
\hline TEEL-1 & TEEL-2 & TEEL-3 \\
\hline 0.00043 & 0.00043 & 0.043 \\
\hline 0.00046 & 0.00046 & 0.046 \\
\hline 0.00021 & 0.0014 & 0.0068 \\
\hline 0.00046 & 0.046 & 0.046 \\
\hline 0.00046 & 0.0046 & 0.046 \\
\hline
\end{tabular}

\section{B.10 Potassium (K)}

In the liquid, potassium is used as a counter-ion for anion analytes, providing a charge balance (together with $\mathrm{Na}$ ). Therefore no liquid-phase compounds are assigned specifically to K. In the wet bulk solids, the new method assigns potassium to potassium nitrate $\left(\mathrm{KNO}_{3}\right)$, nitrate being the most plausible counterion. Because $\mathrm{K}$ is used to supply the charge balance, its output concentration typically differs from the $\mathrm{BBI}$ value.

\section{B.11 Lanthanum (La)}

The new method assigns lanthanum to $\mathrm{La}(\mathrm{OH})_{3}$ in the liquid phase and $\mathrm{LaPO}_{4}$ in the wet bulk solids phase. As shown in Table B.8, the assignment of lanthanum compounds in the liquid phase was based on prevalence. 
Table B.8. Prevalence and Toxicity of Lanthanum Compounds

\begin{tabular}{|c|c|c|c|c|c|}
\hline \multirow[b]{2}{*}{ Analyte: Lanthanum } & \multicolumn{2}{|c|}{$\begin{array}{c}\text { Total over all tanks, } 2002 \text { ESP } \\
\text { Prediction }\end{array}$} & \multicolumn{3}{|c|}{$\begin{array}{l}\text { TEELs expressed in } \\
\text { mmol analyte/m } \mathbf{m}^{3}\end{array}$} \\
\hline & \begin{tabular}{|c|}
$\begin{array}{c}\text { Moles analyte } \\
\text { in liquid in } \\
\text { this form }\end{array}$ \\
\end{tabular} & \begin{tabular}{|c|} 
Moles analyte \\
in dry solid in \\
this form
\end{tabular} & TEEL-1 & TEEL-2 & TEEL-3 \\
\hline Lanthanum fluoride (and complexes) & 3.83E-07 & 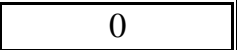 & 0.038 & 0.19 & 1.3 \\
\hline Lanthanum hydroxide (and complexes) & 9.47E-03 & $1.16 \mathrm{E}+04$ & 0.0039 & 0.011 & 0.013 \\
\hline Lanthanum nitrate (and complexes) & $9.43 \mathrm{E}-15$ & 0 & 0.0038 & 0.023 & 1.5 \\
\hline Lanthanum phosphate (and complexes) & $1.26 \mathrm{E}-24$ & $2.63 \mathrm{E}+05$ & 0.0032 & 0.013 & 0.013 \\
\hline $\mathrm{La}^{+3}$ & $5.18 \mathrm{E}-14$ & 0 & & & \\
\hline La acetate and complexes & $3.43 \mathrm{E}-15$ & 0 & & & \\
\hline La chloride and complexes & $2.64 \mathrm{E}-16$ & 0 & & & \\
\hline La carbonate and complexes & $6.49 \mathrm{E}-11$ & 0 & & & \\
\hline La sulfate and complexes & 8.01E-16 & 0 & & & \\
\hline
\end{tabular}

\section{B.12 Manganese (Mn)}

In the new method, manganese is assigned to $\mathrm{Mn}(\mathrm{OH})_{2}$ in both the liquid phase and the wet bulk solid phase. Table B.9 shows the available information. Manganese hydroxide is the prevalent compound in both phases.

Table B.9. Prevalence and Toxicity of Manganese Compounds

\begin{tabular}{||l|c|c||}
\hline \multicolumn{1}{||}{ Analyte: Manganese } & \multicolumn{2}{c||}{$\begin{array}{c}\text { Total over all tanks, 2002 } \\
\text { ESP Prediction }\end{array}$} \\
\cline { 2 - 4 } & $\begin{array}{c}\text { Moles analyte } \\
\text { in liquid in } \\
\text { this form }\end{array}$ & $\begin{array}{c}\text { Moles analyte } \\
\text { in dry solid in } \\
\text { this form }\end{array}$ \\
\hline \hline Manganese carbonate & 0 & $1.90 \mathrm{E}+05$ \\
\hline Manganese dioxide & 0 & 0 \\
\hline Manganese hydroxide (and complexes) & $3.38 \mathrm{E}+05$ & $1.97 \mathrm{E}+06$ \\
\hline Manganese nitrite & 0 & 0 \\
\hline Manganese oxalate (and complexes) & $5.19 \mathrm{E}+02$ & 0 \\
\hline Manganese oxide & 0 & 0 \\
\hline Manganese phosphate & 0 & $5.56 \mathrm{E}+05$ \\
\hline Manganese(II) nitrate (and complexes) & $3.37 \mathrm{E}+00$ & 0 \\
\hline Manganous sulfate & $1.84 \mathrm{E}-01$ & 0 \\
\hline Mn ${ }^{+2}$ & $3.83 \mathrm{E}+00$ & 0 \\
\hline Mn acetate and complexes & $4.68 \mathrm{E}-01$ & 0 \\
\hline Mn chloride and complexes & $4.28 \mathrm{E}-02$ & 0 \\
\hline \hline
\end{tabular}

\begin{tabular}{||c|c|c||}
\hline \multicolumn{3}{|c|}{$\begin{array}{c}\text { TEELs expressed in } \\
\text { mmol analyte/ }\end{array}$} \\
\hline & & \\
TEEL-1 & TEEL-2 & TEEL-3 \\
\hline \hline 0.052 & 0.087 & 4.3 \\
\hline 0.046 & 0.86 & 5.8 \\
\hline 0.056 & 0.084 & 5.6 \\
\hline 0.051 & 0.085 & 3.4 \\
\hline 0.052 & 0.087 & 3.5 \\
\hline 0.0098 & 0.79 & 6.6 \\
\hline 0.051 & 0.085 & 4.2 \\
\hline 0.056 & 0.084 & 2.8 \\
\hline 0.050 & 0.083 & 3.3 \\
\hline \multicolumn{3}{|l}{} \\
\hline
\end{tabular}

\section{B.13 Sodium (Na)}

In the liquid, sodium is used as a counter-ion for anionic analytes, providing a charge balance (together with K). In the wet bulk solids, $\mathrm{Na}$ is used as the only counter-ion for the anionic analytes. Therefore no compounds are assigned specifically to Na. 
Because $\mathrm{Na}$ is used to supply the charge balance, its output concentration typically differs from the BBI value.

\section{B.14 Nickel (Ni)}

The new method defines nickel as being $\mathrm{Ni}(\mathrm{OH})_{2}$ in both the liquid phase and the wet bulk solid phase. Table B.10 shows the available information.

The predominant form of $\mathrm{Ni}$ in solution was nickel hydroxide complexes. Nickel oxalate complexes came a distant second. Nickel hydroxide predominated by about a factor of 40 in the dry solid phase in the predicted total inventory of 2002. Based on prevalence, the hydroxide was therefore assigned to Ni as the liquid-phase and solid-phase compound.

Table B.10. Prevalence and Toxicity of Nickel Compounds

\begin{tabular}{||l|c|c||}
\hline \multirow{2}{*}{\multicolumn{1}{|c|}{ Analyte: Nickel }} & \multicolumn{2}{c||}{$\begin{array}{c}\text { Total over all tanks, 2002 ESP } \\
\text { Prediction }\end{array}$} \\
\cline { 2 - 4 } & $\begin{array}{c}\text { Moles analyte } \\
\text { in liquid in } \\
\text { this form }\end{array}$ & $\begin{array}{c}\text { Moles analyte } \\
\text { in dry solid in } \\
\text { this form }\end{array}$ \\
\hline \hline Nickel oxalate and complexes (liquids) & $2.86 \mathrm{E}+02$ & n/a \\
\hline Nickel oxalate (solids) & n/a & $3.24 \mathrm{E}+04$ \\
\hline Nickel(II) hydroxide and complexes & $7.89 \mathrm{E}+03$ & $2.04 \mathrm{E}+06$ \\
\hline Nickel(II) nitrate and complexes & $2.46 \mathrm{E}+00$ & 0 \\
\hline Nickel(II) nitrite & 0 & 0 \\
\hline Nickel(II) phosphate & 0 & $2.17 \mathrm{E}+04$ \\
\hline Potassium nickelate (Liquids) & 0 & 0 \\
\hline Potassium nickelate (Solids) & 0 & 0 \\
\hline Sodium nickelate (Liquids) & 0 & 0 \\
\hline Sodium nickelate (Solids) & 0 & 0 \\
\hline Ni ${ }^{+2}$ & $7.26 \mathrm{E}+00$ & 0 \\
\hline Ni acetate and complexes & $1.97 \mathrm{E}-02$ & 0 \\
\hline Ni chloride and complexes & $4.89 \mathrm{E}-04$ & 0 \\
\hline Ni fluoride and complexes & $8.79 \mathrm{E}-03$ & 0 \\
\hline Ni sulfate and complexes & $3.96 \mathrm{E}-01$ & 0 \\
\hline \hline
\end{tabular}

\begin{tabular}{|c|c|c|}
\hline \multicolumn{3}{|c|}{$\begin{array}{c}\text { TEELs expressed in } \\
\text { mmol analyte } / \mathbf{m}^{3}\end{array}$} \\
\hline TEEL-1 & TEEL-2 & TEEL-3 \\
\hline 0.0051 & 0.0085 & 0.17 \\
\hline 0.010 & 0.017 & 0.17 \\
\hline 0.0081 & 0.016 & 0.16 \\
\hline 0.016 & 0.016 & 0.16 \\
\hline 0.0020 & 0.0033 & 0.066 \\
\hline 0.0049 & 0.0082 & 0.082 \\
\hline 0.0049 & 0.0073 & 0.17 \\
\hline 0.010 & 0.017 & 0.17 \\
\hline 0.0043 & 0.0087 & 0.17 \\
\hline 0.0087 & 0.017 & 0.17 \\
\hline
\end{tabular}

\section{B.15 Nitrate, Nitrite, and Hydroxide $\left(\mathrm{NO}_{3}, \mathrm{NO}_{2}\right.$, and $\left.\mathrm{OH}\right)$}

The major anions in Hanford tank waste, nitrate, nitrite, and hydroxide, are assigned to compounds in a two-step process.

First, certain metals are assigned these anions as counter-ions. In the liquid phase, $\mathrm{Sr}$ is split between hydroxide, nitrate, and nitrite according to the relative concentrations of the three anions in the liquid. (See the equations for the metals and for $\mathrm{NO}_{2}$ Ratio, $\mathrm{NO}_{3}$ Ratio, and OHRatio in Table A.1.)

In the second step, the amounts of anion consumed by the listed metals are then subtracted from the input anions. (See the equations for Temp2OH, TempNO ${ }_{2}$, and $\mathrm{TempNO}_{3}$ in Table A.1.) The remaining anion concentrations are split between $\mathrm{Na}$ and $\mathrm{K}$ compounds $\left(\mathrm{NaNO}_{3}, \mathrm{NaNO}_{2}, \mathrm{NaOH}, \mathrm{KNO}_{3}, \mathrm{KNO}_{2}\right.$, and $\left.\mathrm{KOH}\right)$ as can be seen in the equations for these compounds in Table B.1. 
In the wet bulk solid phase less accounting is necessary because there are no three-way splits of metals between the anions. All $\mathrm{NO}_{2}$ is allotted to $\mathrm{NaNO}_{2}$ and all $\mathrm{OH}$ to $\mathrm{NaOH}$. The $\mathrm{NO}_{3}$ that remains after assigning part of it to $\mathrm{K}$ (for $\mathrm{KNO}_{3}$ ) is allotted to $\mathrm{NaNO}_{3}$.

Note that the hydroxide in such neutral species as $\mathrm{Al}(\mathrm{OH})_{3}, \mathrm{Bi}(\mathrm{OH})_{3}, \mathrm{Hg}(\mathrm{OH})_{2}$, and many other hydroxides does not need to be subtracted from the input $\mathrm{OH}$. The input $\mathrm{OH}$ is composed only of free hydroxide, and measurements of free $\mathrm{OH}$ do not include the hydroxide that is bound into neutral compounds and complexes. Therefore only the part of the $\mathrm{OH}^{-}$that is used as a counterion for those metal cations that are predicted to be mostly uncomplexed ( $\mathrm{Sr}$, for example) is subtracted from the input hydroxide to give Temp2OH.

A similar process was followed in the old method, though it was complicated by the presence of more metals and complexes that needed to be included in the mass-balance accounting.

\section{B.16 Lead (Pb)}

The new method defines lead as being split between $\mathrm{NaHPbO}_{2}$ and $\mathrm{KHPbO}_{2}$ in the liquid phase. In the wet bulk solid phase lead is assigned to lead hydroxide, $\mathrm{Pb}(\mathrm{OH})_{2}$. Table B.11 shows the available information.

The predominant form of $\mathrm{Pb}$ in solution was $\mathrm{HPbO}_{2}{ }^{-1}$, hydrogen lead hydroxide ion. The available TEELs were for sodium and potassium salts of the ion. These salts were therefore used to represent $\mathrm{Pb}$ in the liquid phase. $\mathrm{Pb}(\mathrm{OH})_{2}$ predominated by a factor of more than 10 over other $\mathrm{Pb}$ compounds in the dry solid phase in the predicted total inventory of 2002. It was therefore assigned to $\mathrm{Pb}$ as the solid-phase compound. Note that it conservatively represents the toxicity of other solid-phase Pb compounds.

Table B.11. Prevalence and Toxicity of Lead Compounds

\begin{tabular}{|c|c|c|}
\hline \multirow[b]{2}{*}{ Analyte: Lead } & \multicolumn{2}{|c|}{$\begin{array}{c}\text { Total over all tanks, } 2002 \\
\text { ESP Prediction }\end{array}$} \\
\hline & $\begin{array}{c}\text { Moles } \\
\text { analyte in } \\
\text { liquid in this } \\
\text { form }\end{array}$ & $\begin{array}{c}\text { Moles } \\
\text { analyte in } \\
\text { dry solid in } \\
\text { this form }\end{array}$ \\
\hline Lead carbonate & 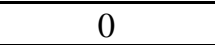 & $1.87 \mathrm{E}+04$ \\
\hline Lead hydroxide and complexes & $1.54 \mathrm{E}-03$ & $3.92 \mathrm{E}+05$ \\
\hline Lead nitrate and complexes & 2.70E-03 & 0 \\
\hline Lead nitrite and complexes & $1.03 \mathrm{E}+02$ & 0 \\
\hline Lead oxalate & $5.41 \mathrm{E}-01$ & 0 \\
\hline Lead oxide & $2.09 \mathrm{E}-01$ & 0 \\
\hline Lead phosphate and complexes & 9.73E-05 & $1.26 \mathrm{E}+04$ \\
\hline Potassium hydrogen lead oxide & 0 & 0 \\
\hline Sodium hydrogen lead oxide & 0 & 0 \\
\hline $\mathrm{Pb}^{+2}$ & $9.82 \mathrm{E}-04$ & 0 \\
\hline $\begin{array}{l}\mathrm{HPbO}_{2}^{-2} \text { (hydrogen lead oxide ion) and } \\
\text { complexes }\end{array}$ & $1.49 \mathrm{E}+03$ & 0 \\
\hline $\mathrm{Pb}$ acetate and complexes & $1.55 \mathrm{E}-03$ & 0 \\
\hline $\mathrm{Pb}$ chloride and complexes & $6.00 \mathrm{E}-05$ & 0 \\
\hline $\mathrm{Pb}$ fluoride and complexes & $1.06 \mathrm{E}-04$ & 0 \\
\hline
\end{tabular}

\begin{tabular}{|c|c|c|}
\hline \multicolumn{3}{|c|}{$\begin{array}{l}\text { TEELs expressed in } \\
\text { mmol analyte/m }\end{array}$} \\
\hline TEEL-1 & TEEL-2 & TEEL-3 \\
\hline 0.00075 & 0.011 & 1.9 \\
\hline 0.00062 & 0.0012 & 0.0062 \\
\hline 0.00068 & 0.0011 & 0.45 \\
\hline 0.00067 & 0.0012 & 0.0050 \\
\hline 0.00068 & 0.0012 & 0.0051 \\
\hline 0.00022 & 0.00022 & 0.45 \\
\hline 0.00074 & 0.11 & 0.55 \\
\hline 0.00021 & 0.00021 & 0.45 \\
\hline 0.00023 & 0.00023 & 0.47 \\
\hline
\end{tabular}




\section{B.17 Phosphate $\left(\mathrm{PO}_{4}\right)$}

In the new method, the liquid-phase phosphate was split between $\mathrm{Na}_{3} \mathrm{PO}_{4}$ and $\mathrm{K}_{3} \mathrm{PO}_{4}$. In the wet bulk solid phase, phosphate was first allotted to $\mathrm{Ca}$, $\mathrm{La}$, and $\mathrm{Zn}$ to form phosphate compounds with those metals. The remaining phosphate was assigned to $\mathrm{Na}_{3} \mathrm{PO}_{4}$ (Table A.1). This approach was consistent with the old method. If the moles of phosphate that are required to form the $\mathrm{Ca}$, La, and $\mathrm{Zn}$ phosphate compounds are in excess of the moles given by the BBI, then no sodium phosphate will be formed and the output phosphate concentration will exceed the BBI value.

\section{B.18 Silicon (Si)}

The new method defines silicon as being represented by disodium and dipotassium metasilicate $\left(\mathrm{Na}_{2} \mathrm{SiO}_{3}\right.$ and $\mathrm{K}_{2} \mathrm{SiO}_{3}$ ) in the liquid phase and by $\mathrm{NaAlSiO}_{4}$ in the wet bulk solid phase. Table B.12 shows the available information.

Table B.12. Prevalence and Toxicity of Silicon Compounds

\begin{tabular}{||l|c|c||}
\hline \multirow{1}{*}{\multicolumn{1}{||}{ Analyte: Silicon }} & \multicolumn{2}{c|}{$\begin{array}{c}\text { Total over all tanks, 2002 } \\
\text { ESP Prediction }\end{array}$} \\
\cline { 2 - 3 } & $\begin{array}{c}\text { Moles analyte } \\
\text { in liquid in } \\
\text { this form }\end{array}$ & $\begin{array}{c}\text { Moles analyte } \\
\text { in dry solid in } \\
\text { this form }\end{array}$ \\
\hline \hline Silica & $7.32 \mathrm{E}+03$ & $2.60 \mathrm{E}+06$ \\
\hline Silicic acid & 0 & 0 \\
\hline Sodium aluminosilicate & 0 & $2.00 \mathrm{E}+07$ \\
\hline Calcium metasilicate & 0 & 0 \\
\hline Sodium metasilicate & 0 & 0 \\
\hline Potassium alumino-silicate & 0 & $4.90 \mathrm{E}+05$ \\
\hline Potassium hydrogen silicate & 0 & 0 \\
\hline Potassium trihydrogen silicate & 0 & 0 \\
\hline Dipotassium dihydrogen silicate & 0 & 0 \\
\hline Dipotassium metasilicate & 0 & 0 \\
\hline Disodium dihydrogen silicate & 0 & 0 \\
\hline Disodium metasilicate & 0 & 0 \\
\hline Sodium hydrogen metasilicate & $4.71 \mathrm{E}+06$ & 0 \\
\hline Sodium trihydrogen silicate & 0 & 0 \\
\hline SiO ${ }_{4}^{-4}$ (silicate) and complexes & $1.07 \mathrm{E}+06$ & 0 \\
\hline Si fluoride and complexes & $9.84 \mathrm{E}-14$ & 0 \\
\hline Calcium hydrogen metasilicate ion & $1.76 \mathrm{E}+02$ & 0 \\
\hline Calcium dihydrogen silicate & $3.59 \mathrm{E}+03$ & 0 \\
\hline \hline
\end{tabular}

\begin{tabular}{|c|c|c|}
\hline \multicolumn{3}{|c|}{$\begin{array}{l}\text { Rev. 21A TEELs expressed in } \\
\text { mmol analyte } / \mathrm{m}^{3}\end{array}$} \\
\hline TEEL-1 & TEEL-2 & TEEL-3 \\
\hline 0.50 & 0.83 & 8.3 \\
\hline 0.13 & 0.64 & 5.1 \\
\hline 0.070 & 0.11 & 3.5 \\
\hline 0.26 & 0.43 & 2.2 \\
\hline 1.2 & 2.0 & 4.1 \\
\hline 0.19 & 0.32 & 3.2 \\
\hline 0.26 & 0.43 & 2.2 \\
\hline 0.22 & 0.37 & 1.9 \\
\hline 0.17 & 0.29 & 1.5 \\
\hline 0.097 & 0.81 & 3.2 \\
\hline 0.21 & 0.36 & 1.8 \\
\hline 0.10 & 0.61 & 4.1 \\
\hline 0.12 & 0.75 & 4.0 \\
\hline 0.25 & 0.42 & 2.1 \\
\hline
\end{tabular}

In the liquid phase, the dominant silicon compound is sodium hydrogen metasilicate $\left(\mathrm{NaHSiO}_{3}\right)$. Because no TEEL was available for potassium hydrogen metasilicate, the metasilicates $\left(\mathrm{Na}_{2} \mathrm{SiO}_{3}\right.$ and $\left.\mathrm{K}_{2} \mathrm{SiO}_{3}\right)$ were assigned instead. These compounds are a good match for the prevalent ones both chemically and toxicologically. Only the portion of the liquid-phase silicon that exceeds the moles of calcium in the liquid is assigned to the metasilicates. Section B.4 discusses this constraint more completely. 
In the solid phase, the dominant compounds are aluminosilicates. In the new model all wet-solid-phase Si is assigned to the aluminosilicate; an amount of $\mathrm{Al}$ that is equal to the $\mathrm{Si}$ is also assigned to $\mathrm{NaAlSiO}_{4}$, and any $\mathrm{Al}$ in excess of that is assigned to $\mathrm{Al}(\mathrm{OH})_{3}$ in the solids. In tanks where the Si concentration exceeds the $\mathrm{Al}$, this approach will produce an $\mathrm{Al}$ concentration in the solids that exceeds the $\mathrm{BBI}$ value and will assign all Al to the aluminosilicate and none to aluminum hydroxide. These effects are unavoidable if Si is to be represented in a reasonably conservative way.

\section{B.19 Sulfate $\left(\mathrm{SO}_{4}\right)$}

In the new method, sulfate was split between $\mathrm{Na}_{2} \mathrm{SO}_{4}$ and $\mathrm{K}_{2} \mathrm{SO}_{4}$ in the liquid and was assigned to $\mathrm{Na}_{2} \mathrm{SO}_{4}$ in the wet bulk solid (Table A.1). This was essentially the same approach as was used in the old method. In the old method the sulfate double salts predicted by the ESP model were split into single salts for the purpose of toxicological assessment; this step in effect assigned all solid sulfate to $\mathrm{Na}_{2} \mathrm{SO}_{4}$.

\section{B.20 Strontium (Sr)}

In the new method, strontium is defined as being split between $\operatorname{Sr}(\mathrm{OH})_{2}, \operatorname{Sr}\left(\mathrm{NO}_{2}\right)_{2}$, and $\operatorname{Sr}\left(\mathrm{NO}_{3}\right)_{2}$ in the liquid phase. In the wet bulk solid phase strontium is assigned to $\mathrm{SrCO}_{3}$. See Table B.13 for the data.

The predominant form of $\mathrm{Sr}$ in solution was $\mathrm{Sr}(\mathrm{OH})_{2}$ and related complexes, with $\mathrm{Sr}^{2+}$ ion (which is balanced chiefly by $\mathrm{NO}_{2}{ }^{-}, \mathrm{NO}_{3}{ }^{-}$, and $\mathrm{OH}-$ ) and strontium nitrate complexes making contributions of similar magnitude. This being the case, Sr was split among the three major anions (hydroxide, nitrate, and nitrite) in the new method (Table A.1). The split is somewhat conservative toxicologically because it includes the nitrite with its high toxicity.

The two prevalent solids were strontium carbonate and phosphate. The carbonate was chosen because it outweighed the phosphate by a factor of nearly twenty and was toxicologically conservative.

Table B.13. Prevalence and Toxicity of Strontium Compounds

\begin{tabular}{||l|c|c||}
\hline \multirow{1}{*}{\multicolumn{1}{||}{ Analyte: Strontium }} & \multicolumn{2}{|c||}{$\begin{array}{c}\text { Total over all tanks, 2002 } \\
\text { ESP Prediction }\end{array}$} \\
\cline { 2 - 3 } & $\begin{array}{c}\text { Moles analyte } \\
\text { in liquid in } \\
\text { this form }\end{array}$ & $\begin{array}{c}\text { Moles analyte } \\
\text { in dry solid in } \\
\text { this form }\end{array}$ \\
\hline \hline Strontium carbonate & 0 & $4.51 \mathrm{E}+05$ \\
\hline Strontium hydroxide and complexes & $3.67 \mathrm{E}+02$ & 0 \\
\hline Strontium nitrate and complexes & $2.19 \mathrm{E}+02$ & 0 \\
\hline Strontium nitrite & 0 & 0 \\
\hline Strontium oxalate and complexes & $3.55 \mathrm{E}+00$ & 0 \\
\hline Strontium phosphate and complexes & $8.98 \mathrm{E}+01$ & $2.68 \mathrm{E}+04$ \\
\hline Strontium sulfate & 0 & 0 \\
\hline Potassium strontium phosphate & 0 & 0 \\
\hline Sodium strontium phosphate & 0 & 0 \\
\hline Sr ${ }^{+2}$ & $2.40 \mathrm{E}+02$ & 0 \\
\hline Sr acetate and complexes & $9.37 \mathrm{E}+00$ & 0 \\
\hline Sr fluoride and complexes & $1.14 \mathrm{E}+00$ & 0 \\
\hline \hline
\end{tabular}

\begin{tabular}{||c|c|c||}
\hline \multicolumn{3}{||c|}{$\begin{array}{c}\text { TEELs expressed in } \\
\text { mmol analyte/ }\end{array}$} \\
\hline & & \\
TEEL-1 & TEEL-2 & TEEL-3 \\
\hline 0.14 & 0.14 & 0.14 \\
\hline 0.0062 & 0.16 & 0.62 \\
\hline 0.14 & 0.24 & 2.4 \\
\hline 0.00056 & 0.0042 & 0.42 \\
\hline 0.14 & 0.34 & 0.43 \\
\hline 0.20 & 3.3 & 3.3 \\
\hline 0.16 & 0.27 & 1.4 \\
\hline 0.14 & 0.23 & 2.3 \\
\hline 0.15 & 0.24 & 2.4 \\
\hline \multicolumn{3}{|l}{} \\
\hline
\end{tabular}




\section{B.21 Total Inorganic Carbon as Carbonate (TIC as $\mathrm{CO}_{3}$ )}

In the new method, carbonate was assigned to $\mathrm{UO}_{2} \mathrm{CO}_{3}$ in the liquid, which consumed as many moles of $\mathrm{CO}_{3}$ as there were of $\mathrm{U}$. The remaining liquid-phase carbonate was split between $\mathrm{Na}_{2} \mathrm{CO}_{3}$ and $\mathrm{K}_{2} \mathrm{CO}_{3}$. In the wet bulk solid phase, carbonate was first allotted to $\mathrm{Ag}$ and $\mathrm{Sr}$ to form carbonate compounds with those metals. The remaining carbonate was assigned to $\mathrm{Na}_{3} \mathrm{CO}_{3}$ (Table A.1). This approach was consistent with the old method. If $\mathrm{Ag}$ and $\mathrm{Sr}$ are high compared to $\mathrm{CO}_{3}$, the same type of mass-balance changes may occur for carbonate that were described for phosphate (Section B.19).

\section{B.22 Total Organic Carbon (TOC)}

In the old method, the TOC was split between oxalate and acetate according to the fraction of the carbon that was present in the liquid phase. (See Section 2.1.) In the new method all of the TOC is assigned to oxalate, whether it is in the wet bulk solids phase or the liquid phase.

Table B.14 gives the available information about TOC compounds. It can be seen that sodium oxalate is more toxic than, or approximately as toxic as, the other organic salts. It is also more toxic than most non-salt organic compounds. (Oxalic acid, though more toxic than sodium oxalate, was predicted to be present in such a small amount that even if it were all present in one tank, the effect on the overall waste toxicity would be negligible.) Sodium oxalate was chosen for use in the wet bulk solids in the new method because of its toxicity, as an attempt to represent all other trace organic anions and compounds in a way that is more often than not conservative.

Table B.14. Prevalence and Toxicity of TOC Salts

\begin{tabular}{||l|c|c||}
\hline \multicolumn{1}{||c|}{ Analyte: TOC } & $\begin{array}{c}\text { Total over all tanks, 2002 ESP } \\
\text { Prediction }\end{array}$ \\
\cline { 2 - 4 } & $\begin{array}{c}\text { Moles analyte } \\
\text { in liquid in } \\
\text { this form }\end{array}$ & $\begin{array}{c}\text { Moles analyte } \\
\text { in dry solid in } \\
\text { this form }\end{array}$ \\
\hline \hline Sodium acetate & $6.13 \mathrm{E}+07$ & 0 \\
\hline Potassium acetate & $2.27 \mathrm{E}+05$ & 0 \\
\hline Sodium oxalate & 0 & $3.50 \mathrm{E}+07$ \\
\hline Acetic acid & $2.51 \mathrm{E}+00$ & 0 \\
\hline Oxalic acid & $4.44 \mathrm{E}-10$ & 0 \\
\hline Sodium formate & not in BBI & not in BBI \\
\hline Sodium citrate & not in BBI & not in BBI \\
\hline Tetrasodium ethylenediaminetetraacetate & not in BBI & not in BBI \\
(EDTA) & $1.43 \mathrm{E}+07$ & 0 \\
\hline Acetate ion & $1.75 \mathrm{E}+06$ & 0 \\
\hline Oxalate ion & & \\
\hline \hline
\end{tabular}

\begin{tabular}{||c|c|c||}
\hline \multicolumn{3}{|c|}{$\begin{array}{c}\text { TEELs expressed in } \\
\text { mmol analyte/m }\end{array}$} \\
\hline & & \\
TEEL-1 & TEEL-2 & TEEL-3 \\
\hline \hline 0.98 & 7.3 & 12 \\
\hline 0.82 & 5.1 & 10 \\
\hline 0.45 & 0.75 & 0.75 \\
\hline 0.40 & 2.9 & 20 \\
\hline 0.044 & 0.11 & 11 \\
\hline 1.8 & 7.4 & 7.4 \\
\hline 5.0 & 8.4 & 84 \\
\hline 0.11 & 0.79 & 3.9 \\
\hline \multicolumn{3}{|l}{} \\
\hline
\end{tabular}

\section{B.23 Uranium (U)}

The new method assigns liquid-phase uranium to $\mathrm{UO}_{2} \mathrm{CO}_{3}$. The uranium in the wet bulk solids is assigned to sodium diuranate, $\mathrm{Na}_{2} \mathrm{U}_{2} \mathrm{O}_{7}$. Table B.15 gives the available information. 
Uranyl carbonate was essentially the only form of uranium that appeared in the liquid, and sodium diuranate was the only form predicted by the ESP model in the dry solid phase. The uranium compounds in Table B.15 all have about the same toxicity in terms of their uranium content, so the assigned species can be considered representative.

Table B.15. Prevalence and Toxicity of Uranium Compounds

\begin{tabular}{||l|c|c||}
\hline \multicolumn{1}{||}{ Analyte: Uranium } & \multicolumn{2}{c|}{$\begin{array}{c}\text { Total over all tanks, 2002 } \\
\text { ESP Prediction }\end{array}$} \\
\cline { 2 - 4 } & $\begin{array}{c}\text { Moles analyte } \\
\text { in liquid in } \\
\text { this form }\end{array}$ & $\begin{array}{c}\text { Moles analyte } \\
\text { in dry solid in } \\
\text { this form }\end{array}$ \\
\hline \hline Uranyl hydroxide and complexes (liquid) & $3.38 \mathrm{E}-05$ & n/a \\
\hline Uranyl nitrate & 0 & 0 \\
\hline Uranyl nitrite (liquid) & 0 & n/a \\
\hline Sodium diuranate (solid) & n/a & $2.42 \mathrm{E}+06$ \\
\hline Uranyl carbonate (liquids) & 0 & n/a \\
\hline UO ${ }_{2}^{+2}$ & $4.09 \mathrm{E}-10$ & 0 \\
\hline Uranyl acetate and complexes & $1.75 \mathrm{E}-09$ & 0 \\
\hline Uranyl oxalate and complexes & $1.20 \mathrm{E}-04$ & 0 \\
\hline Uranyl chloride and complexes & $9.18 \mathrm{E}-12$ & 0 \\
\hline Uranyl carbonate and complexes & $1.06 \mathrm{E}+05$ & 0 \\
\hline Uranyl fluoride and complexes & $1.03 \mathrm{E}-04$ & 0 \\
\hline Uranyl sulfate and complexes & $1.04 \mathrm{E}-08$ & 0 \\
\hline \hline
\end{tabular}

\begin{tabular}{|c|c|c|}
\hline \multicolumn{3}{|c|}{$\begin{array}{l}\text { TEELs expressed in } \\
\text { mmol analyte/ } \mathbf{m}^{3}\end{array}$} \\
\hline TEEL-1 & TEEL-2 & TEEL-3 \\
\hline 0.0025 & $\begin{array}{c}0.0041 \\
\end{array}$ & 0.041 \\
\hline 0.0025 & 0.0038 & 0.038 \\
\hline 0.0021 & 0.0041 & 0.041 \\
\hline 0.0024 & 0.0047 & 0.047 \\
\hline 0.0023 & 0.0038 & 0.038 \\
\hline
\end{tabular}

\section{B.24 Zirconium (Zr)}

In the new method, all liquid-phase zirconium is assigned to $\operatorname{Zr}(\mathrm{OH})_{4}$ and all the zirconium in the wet bulk solids is assigned to $\mathrm{ZrO}_{2}$. As can be seen from Table B.16, this assignment is consistent with the prevalent compounds predicted by the ESP model for the 177 tanks based on their May 2002 inventories.

Table B.16. Prevalence and Toxicity of Zirconium Compounds

\begin{tabular}{||l|c|c||}
\hline \multirow{3}{*}{\multicolumn{1}{||}{ Analyte: Zirconium }} & \multicolumn{2}{c|}{$\begin{array}{c}\text { Total over all tanks, 2002 } \\
\text { ESP Prediction }\end{array}$} \\
\cline { 2 - 3 } & $\begin{array}{c}\text { Moles analyte } \\
\text { in liquid in } \\
\text { this form }\end{array}$ & $\begin{array}{c}\text { Moles analyte } \\
\text { in dry solid in } \\
\text { this form }\end{array}$ \\
\hline \hline Zirconium dioxide & 0 & $4.34 \mathrm{E}+06$ \\
\hline Zirconium hydroxide and complexes & $1.54 \mathrm{E}+04$ & 0 \\
\hline Monopotassium zirconium(IV) hydroxide & 0 & 0 \\
\hline Monosodium zirconium hydroxide & 0 & 0 \\
\hline Potassium zirconate & 0 & 0 \\
\hline Sodium zirconate & 0 & 0 \\
\hline$Z r^{+4}$ & 0 & 0 \\
\hline$Z$ Zr oxalate and complexes & $1.20 \mathrm{E}-15$ & 0 \\
\hline$Z$ Zr fluoride and complexes & $1.84 \mathrm{E}-09$ & 0 \\
\hline \hline
\end{tabular}

\begin{tabular}{||c|c|c||}
\hline \hline \multicolumn{3}{|c|}{$\begin{array}{c}\text { TEELS expressed in } \\
\text { mmol analyte/ }\end{array}$} \\
\hline & & \\
\hline & & \\
TEEL-1 & TEEL-2 & TEEL-3 \\
\hline \hline 0.10 & 0.10 & 0.28 \\
\hline 0.094 & 0.094 & 0.25 \\
\hline 0.12 & 0.12 & 0.58 \\
\hline 0.10 & 0.10 & 0.50 \\
\hline 0.11 & 0.11 & 0.28 \\
\hline 0.11 & 0.11 & 0.27 \\
\hline \multicolumn{3}{|l}{} \\
\hline
\end{tabular}


Appendix C - Default Free Hydroxide Concentration Inputs 



\section{Appendix C - Default Free Hydroxide Concentration Inputs}

Table C.1. Concentrations Used in Calculating the Default Free $\mathrm{OH}$ in the New SOF Calculation Method

\begin{tabular}{|c|c|c|}
\hline Tank & $\begin{array}{c}\mu \mathrm{g} / \mathrm{mL} \\
\text { free } \mathrm{OH} \\
\text { in liquid }\end{array}$ & $\begin{array}{c}\mu \mathrm{g} / \mathrm{mL} \\
\mathrm{NO}_{2}^{-} \text {in } \\
\text { liquid }\end{array}$ \\
\hline 241-A-101 & 62,602 & 180,419 \\
\hline 241-A-102 & 19,813 & 101,974 \\
\hline 241-A-103 & 48,218 & 149,496 \\
\hline 241-A-104 & 82,094 & 38,887 \\
\hline 241-A-105 & 89,717 & 5,025 \\
\hline 241-A-106 & 95.1 & 283,966 \\
\hline 241-AN-101 & 25,271 & 44,625 \\
\hline 241-AN-102 & 14,831 & 117,543 \\
\hline 241-AN-103 & 117,281 & 174,543 \\
\hline 241-AN-104 & 88,689 & 124,301 \\
\hline 241-AN-105 & 70922 & 124,969 \\
\hline 241-AN-106 & 4,048 & 82,651 \\
\hline 241-AN-107 & 13.8 & 70,430 \\
\hline 241-AP-101 & 31,677 & 41,422 \\
\hline 241-AP-102 & 18,856 & 36,852 \\
\hline 241-AP-103 & 12,319 & 119,477 \\
\hline 241-AP-104 & 20,862 & 73,140 \\
\hline 241-AP-105 & 16,654 & 124,041 \\
\hline 241-AP-106 & 16,104 & 41,985 \\
\hline 241-AP-107 & 25,869 & 58,799 \\
\hline 241-AP-108 & 13,479 & 51,683 \\
\hline 241-AW-101 & 99,566 & 122,852 \\
\hline 241-AW-102 & 29,311 & 54,314 \\
\hline 241-AW-103 & 17,542 & 39,834 \\
\hline 241-AW-104 & 40,896 & 62,226 \\
\hline 241-AW-105 & 5,878 & 8,483 \\
\hline 241-AW-106 & 29,010 & 153,828 \\
\hline 241-AX-101 & 52,967 & 185,106 \\
\hline 241-AX-102 & 456 & 74,732 \\
\hline 241-AX-103 & 34,650 & 132,422 \\
\hline 241-AX-104 & 22.5 & 6,864 \\
\hline 241-AY-101 & 49,255 & 51,170 \\
\hline 241-AY-102 & 16,828 & 40,267 \\
\hline 241-AZ-101 & 8,738 & 59,393 \\
\hline 241-AZ-102 & 664 & 32,398 \\
\hline 241-B-101 & 38,548 & 150,475 \\
\hline 241-B-102 & 4,742 & 33,449 \\
\hline
\end{tabular}

C.1 
Table C.1. (contd.)

\begin{tabular}{||l|c|c||}
\hline \hline Tank & $\begin{array}{c}\mu \mathrm{g} / \mathrm{mL} \\
\text { free } \mathrm{OH} \\
\text { in liquid }\end{array}$ & $\begin{array}{c}\mu \mathrm{g} / \mathrm{mL} \mathrm{NO}_{2}{ }^{-} \\
\text {in liquid }\end{array}$ \\
\hline \hline $241-\mathrm{B}-103$ & 8,104 & 37,738 \\
\hline $241-\mathrm{B}-104$ & 3.27 & 4,817 \\
\hline $241-\mathrm{B}-105$ & 28,999 & 47,733 \\
\hline $241-\mathrm{B}-106$ & 8.24 & 13,367 \\
\hline $241-\mathrm{B}-107$ & 6.77 & 8,163 \\
\hline $241-\mathrm{B}-108$ & 28,900 & 64,183 \\
\hline $241-\mathrm{B}-109$ & 20,875 & 93,805 \\
\hline $241-\mathrm{B}-110$ & 2,658 & 18,941 \\
\hline $241-\mathrm{B}-111$ & 0.074 & 67,257 \\
\hline $241-\mathrm{B}-112$ & 5,680 & 44,119 \\
\hline $241-\mathrm{B}-201$ & 96.6 & 1,268 \\
\hline $241-\mathrm{B}-202$ & 3,830 & 1,405 \\
\hline $241-\mathrm{B}-203$ & 75.5 & 871 \\
\hline $241-\mathrm{B}-204$ & 486 & 721 \\
\hline $241-\mathrm{BX}-101$ & 107 & 29,505 \\
\hline $241-\mathrm{BX}-102$ & 0.333 & 10,972 \\
\hline $241-\mathrm{BX}-103$ & 88.4 & 20,268 \\
\hline $241-\mathrm{BX}-104$ & 2,151 & 61,105 \\
\hline $241-\mathrm{BX}-105$ & 3,770 & 39,953 \\
\hline $241-\mathrm{BX}-106$ & 50.9 & 66,878 \\
\hline $241-\mathrm{BX}-107$ & 6.15 & 16,374 \\
\hline $241-\mathrm{BX}-108$ & 15.6 & 67,067 \\
\hline $241-\mathrm{BX}-109$ & 32.1 & 32,446 \\
\hline $241-\mathrm{BX}-110$ & 42,719 & 94,811 \\
\hline $241-\mathrm{BX}-111$ & 69,267 & 74,128 \\
\hline $241-\mathrm{BX}-112$ & 3,876 & 50,673 \\
\hline $241-\mathrm{BY}-101$ & 70,001 & 48,200 \\
\hline $241-\mathrm{BY}-102$ & 32,046 & 47,793 \\
\hline $241-\mathrm{BY}-103$ & 34,945 & 43,451 \\
\hline $241-\mathrm{BY}-104$ & 17,539 & 115,975 \\
\hline $241-\mathrm{BY}-105$ & 5,359 & 57,950 \\
\hline $241-\mathrm{BY}-106$ & 35,360 & 72,154 \\
\hline $241-\mathrm{BY}-107$ & 60,139 & 99,707 \\
\hline $241-\mathrm{BY}-108$ & 111,743 & 104,764 \\
\hline $241-\mathrm{BY}-109$ & 33,190 & 70,125 \\
\hline $241-\mathrm{BY}-110$ & 38,878 & 94,193 \\
\hline $241-\mathrm{BY}-111$ & 73,048 & 65,907 \\
\hline $241-\mathrm{BY}-112$ & 87,912 & 105,861 \\
\hline $241-\mathrm{C}-101$ & 15.7 & 66,948 \\
\hline $241-\mathrm{C}-102$ & 67.1 & 12,180 \\
\hline
\end{tabular}


Table C.1. (contd.)

\begin{tabular}{|c|c|c|}
\hline Tank & $\begin{array}{c}\mu g / m L \\
\text { free } \mathrm{OH} \\
\text { in liquid }\end{array}$ & $\begin{array}{c}\mu \mathrm{g} / \mathrm{mL} \mathrm{NO}_{2} \\
\text { in liquid }\end{array}$ \\
\hline 241-C-103 & 245 & 36,033 \\
\hline 241-C-104 & 33,369 & 41,615 \\
\hline 241-C-105 & 18,054 & 40,768 \\
\hline 241-C-106 & 675 & 11,976 \\
\hline 241-C-107 & 162 & 43,946 \\
\hline 241-C-108 & 63.1 & 49,591 \\
\hline 241-C-109 & 62.9 & 89,904 \\
\hline 241-C-110 & 71.1 & 13,346 \\
\hline 241-C-111 & 0.934 & 81,078 \\
\hline 241-C-112 & 5.53 & 79,220 \\
\hline 241-C-201 & 1,954 & 38,780 \\
\hline 241-C-202 & 0.217 & 116,812 \\
\hline 241-C-203 & 0.390 & 67,691 \\
\hline 241-C-204 & 1.04 & 19,182 \\
\hline 241-S-101 & 62,111 & 109,213 \\
\hline 241-S-102 & 15,989 & 104,245 \\
\hline 241-S-103 & 28,062 & 138,536 \\
\hline 241-S-104 & 22,118 & 63,477 \\
\hline 241-S-105 & 29,925 & 138,503 \\
\hline 241-S-106 & 29,500 & 79,041 \\
\hline 241-S-107 & 12,937 & 50,514 \\
\hline 241-S-108 & 23,451 & 138,969 \\
\hline 241-S-109 & 64,359 & 19,845 \\
\hline $241-S-110$ & 31,707 & 92,358 \\
\hline 241-S-111 & 56,869 & 87,130 \\
\hline 241-S-112 & 80,887 & 73,743 \\
\hline 241-SX-101 & 113,650 & 66,137 \\
\hline 241-SX-102 & 29,740 & 143,609 \\
\hline 241-SX-103 & 14,157 & 132,247 \\
\hline 241-SX-104 & 34,497 & 117,274 \\
\hline 241-SX-105 & 47,319 & 142,133 \\
\hline 241-SX-106 & 42,106 & 150,208 \\
\hline 241-SX-107 & 49,212 & 93,395 \\
\hline 241-SX-108 & 35,205 & 45,254 \\
\hline 241-SX-109 & 81,312 & 103,533 \\
\hline 241-SX-110 & 62,254 & 94,467 \\
\hline 241-SX-111 & 53,240 & 90,000 \\
\hline 241-SX-112 & 55,393 & 98,123 \\
\hline 241-SX-113 & 31.4 & 5,581 \\
\hline 241-SX-114 & 69,838 & 94,111 \\
\hline
\end{tabular}

C.3 
Table C.1. (contd.)

\begin{tabular}{|c|c|c|}
\hline Tank & $\begin{array}{c}\mu g / m L \\
\text { free } \mathrm{OH} \\
\text { in liquid }\end{array}$ & $\begin{array}{c}\mu \mathrm{g} / \mathrm{mL} \mathrm{NO}_{2} \\
\text { in liquid }\end{array}$ \\
\hline 241-SX-115 & 180 & 4,031 \\
\hline 241-SY-101 & 24,303 & 89,211 \\
\hline 241-SY-102 & 35,533 & 91,921 \\
\hline 241-SY-103 & 51,507 & 164,429 \\
\hline 241-T-101 & 14,276 & 56,951 \\
\hline 241-T-102 & 62.3 & 33,909 \\
\hline 241-T-103 & 112 & 28,113 \\
\hline 241-T-104 & 18.8 & 6,864 \\
\hline 241-T-105 & 19,400 & 51,863 \\
\hline 241-T-106 & 4.14 & 50,999 \\
\hline 241-T-107 & 12.1 & 21,141 \\
\hline 241-T-108 & 8,509 & 34,973 \\
\hline 241-T-109 & 8.43 & 11,133 \\
\hline 241-T-110 & 2.86 & 7,436 \\
\hline 241-T-111 & 0.667 & 957 \\
\hline 241-T-112 & 20,574 & 37,797 \\
\hline 241-T-201 & 1,651 & 526 \\
\hline 241-T-202 & 1,831 & 792 \\
\hline 241-T-203 & 90 & 403 \\
\hline 241-T-204 & 1727 & 356 \\
\hline 241-TX-101 & 44,060 & 101,795 \\
\hline 241-TX-102 & 4,412 & 88,028 \\
\hline 241-TX-103 & 1,624 & 91,840 \\
\hline 241-TX-104 & 4,096 & 76,746 \\
\hline 241-TX-105 & 23,693 & 93,639 \\
\hline 241-TX-106 & 1,767 & 88,875 \\
\hline 241-TX-107 & 334 & 149,074 \\
\hline 241-TX-108 & 350 & 85,259 \\
\hline 241-TX-109 & 4,816 & 18,955 \\
\hline 241-TX-110 & 298 & 75,742 \\
\hline 241-TX-111 & 267 & 72,396 \\
\hline 241-TX-112 & 411 & 88,049 \\
\hline 241-TX-113 & 0.092 & 17,378 \\
\hline 241-TX-114 & 358 & 79,820 \\
\hline 241-TX-115 & 399 & 88,901 \\
\hline 241-TX-116 & 0.718 & 36,485 \\
\hline 241-TX-117 & 7.56 & 64,903 \\
\hline 241-TX-118 & 4.61 & 64,989 \\
\hline 241-TY-101 & 0.010 & 35,080 \\
\hline 241-TY-102 & 0.146 & 65,212 \\
\hline
\end{tabular}


Table C.1. (contd.)

\begin{tabular}{|c|c|c|}
\hline Tank & $\begin{array}{c}\mu g / m L \\
\text { free } \mathrm{OH} \\
\text { in liquid }\end{array}$ & $\begin{array}{c}\mu \mathrm{g} / \mathrm{mL} \mathrm{NO}_{2}^{-} \\
\text {in liquid } \\
\end{array}$ \\
\hline 241-TY-103 & "16.0 & 87,701 \\
\hline 241-TY-104 & 13.7 & 91,776 \\
\hline 241-TY-105 & 39.9 & 61,481 \\
\hline 241-TY-106 & 1.30 & 27,941 \\
\hline 241-U-101 & 40,037 & 92,112 \\
\hline 241-U-102 & 409 & 104,333 \\
\hline 241-U-103 & 62,786 & 117,164 \\
\hline 241-U-104 & 510 & 50,276 \\
\hline 241-U-105 & 20,824 & 149,142 \\
\hline 241-U-106 & 426 & 94,429 \\
\hline 241-U-107 & 20,800 & 128,131 \\
\hline 241-U-108 & 66,326 & 139,926 \\
\hline 241-U-109 & 3,311 & 136,897 \\
\hline 241-U-110 & 13,919 & 19,695 \\
\hline 241-U-111 & 34,807 & 114,870 \\
\hline 241-U-112 & 10.5 & 9,498 \\
\hline 241-U-201 & 18,533 & 37,472 \\
\hline 241-U-202 & 18,226 & 36,349 \\
\hline 241-U-203 & 16,621 & 32,670 \\
\hline 241-U-204 & 1,300 & 39,118 \\
\hline \multicolumn{3}{|c|}{$\begin{array}{l}\text { The predicted } \mathrm{NO}_{2}^{-} \text {concentration, which is } \\
\text { derived from the ESP runs supporting Cowley et } \\
\text { al. (2003), is used solely as a liquid tracer to } \\
\text { calculate the default free } \mathrm{OH} \text { in bulk solids } \\
\text { phases where no } \mathrm{BBI} \text { data are available. It is } \\
\text { not used to calculate any } \mathrm{NO}_{2} \text { concentrations. }\end{array}$} \\
\hline
\end{tabular}



Appendix D -

Estimated Dry-Solid Volume Fraction in Wet Bulk Solids 



\section{Appendix D - \\ Estimated Dry-Solid Volume Fraction in Wet Bulk Solids}

Table D.1. Estimated Dry-Solid Volume Fraction in the Average

Wet Bulk Solids, Based on the 2002 BBI and ESP Predictions

\begin{tabular}{|c|c|c|}
\hline Tank & $\begin{array}{c}\text { Solid } \\
\text { volume } \\
\text { fraction in } \\
\text { wet bulk } \\
\text { solids }\end{array}$ & $\begin{array}{c}\text { Volume } \\
\text { fraction of } \\
\text { wet bulk } \\
\text { solids in } \\
\text { total waste }\end{array}$ \\
\hline 241-A-101 & 0.279 & 0.446 \\
\hline 241-A-102 & 0.122 & 0.712 \\
\hline 241-A-103 & 0.190 & 0.742 \\
\hline 241-A-104 & 0.211 & 1 \\
\hline 241-A-105 & 0.239 & 1 \\
\hline 241-A-106 & 0.313 & 1 \\
\hline 241-AN-101* & 1 & 0 \\
\hline 241-AN-102 & 0.809 & 0.129 \\
\hline 241-AN-103 & 0.393 & 0.449 \\
\hline 241-AN-104 & 0.239 & 0.455 \\
\hline 241-AN-105 & 0.199 & 0.424 \\
\hline 241-AN-106 & 0.134 & 0.455 \\
\hline 241-AN-107 & 0.133 & 0.237 \\
\hline 241-AP-101 ${ }^{*}$ & 1 & 0 \\
\hline 241-AP-102* & 1 & 0 \\
\hline 241-AP-103* & 1 & 0 \\
\hline 241-AP-104 & 1 & 0 \\
\hline 241-AP-105 & $1.145^{* *}$ & 0.078 \\
\hline 241-AP-106 ${ }^{*}$ & 1 & 0 \\
\hline 241-AP-107* & 1 & 0 \\
\hline 241-AP-108* & 1 & 0 \\
\hline 241-AW-101 & 0.324 & 0.329 \\
\hline 241-AW-102 & 0.930 & 0.029 \\
\hline 241-AW-103 & 0.163 & 0.284 \\
\hline 241-AW-104 & 0.097 & 0.542 \\
\hline 241-AW-105 & 0.105 & 0.448 \\
\hline 241-AW-106 & 0.204 & 0.812 \\
\hline 241-AX-101 & 0.305 & 0.536 \\
\hline 241-AX-102 & 0.278 & 1 \\
\hline 241-AX-103 & 0.095 & 0.768 \\
\hline
\end{tabular}

D.1 
Table D.1. (contd.)

\begin{tabular}{|c|c|c|}
\hline Tank & $\begin{array}{c}\text { Solid } \\
\text { volume } \\
\text { fraction in } \\
\text { wet bulk } \\
\text { solids }\end{array}$ & $\begin{array}{c}\text { Volume } \\
\text { fraction of } \\
\text { wet bulk } \\
\text { solids in } \\
\text { total waste }\end{array}$ \\
\hline 241-AX-104 & 0.395 & 1 \\
\hline 241-AY-101 & 0.339 & 0.447 \\
\hline 241-AY-102 & 0.162 & 0.213 \\
\hline 241-AZ-101 & 0.232 & 0.047 \\
\hline 241-AZ-102 & 0.111 & 0.105 \\
\hline 241-B-101 & 0.341 & 0.818 \\
\hline 241-B-102 & 0.881 & 0.661 \\
\hline 241-B-103 & 0.852 & 0.754 \\
\hline 241-B-104 & 0.116 & 0.974 \\
\hline 241-B-105 & 0.801 & 0.932 \\
\hline 241-B-106 & 0.227 & 0.991 \\
\hline 241-B-107 & 0.480 & 0.884 \\
\hline 241-B-108 & 0.846 & 0.825 \\
\hline 241-B-109 & $1.027^{* *}$ & 0.850 \\
\hline 241-B-110 & 0.190 & 0.996 \\
\hline 241-B-111 & 0.112 & 0.996 \\
\hline 241-B-112 & 0.204 & 0.795 \\
\hline 241-B-201 & 0.059 & 1 \\
\hline 241-B-202 & 0.038 & 1 \\
\hline 241-B-203 & 0.025 & 0.990 \\
\hline 241-B-204 & 0.028 & 0.984 \\
\hline 241-BX-101 & 0.278 & 1 \\
\hline 241-BX-102 & 0.211 & 1 \\
\hline 241-BX-103 & 0.205 & 0.848 \\
\hline 241-BX-104 & 0.346 & 0.971 \\
\hline 241-BX-105 & 0.315 & 0.934 \\
\hline 241-BX-106 & 0.506 & 1 \\
\hline 241-BX-107 & 0.302 & 1 \\
\hline 241-BX-108 & 0.521 & 1 \\
\hline 241-BX-109 & 0.156 & 1 \\
\hline 241-BX-110 & 0.855 & 0.831 \\
\hline 241-BX-111 & 0.636 & 0.913 \\
\hline 241-BX-112 & 0.274 & 0.992 \\
\hline
\end{tabular}


Table D.1. (contd.)

\begin{tabular}{|c|c|c|}
\hline Tank & $\begin{array}{c}\text { Solid } \\
\text { volume } \\
\text { fraction in } \\
\text { wet bulk } \\
\text { solids }\end{array}$ & $\begin{array}{l}\text { Volume } \\
\text { fraction of } \\
\text { wet bulk } \\
\text { solids in } \\
\text { total waste }\end{array}$ \\
\hline 241-BY-101 & 0.791 & 0.949 \\
\hline 241-BY-102 & 0.330 & 0.856 \\
\hline 241-BY-103 & 0.647 & 0.864 \\
\hline 241-BY-104 & 0.426 & 0.878 \\
\hline 241-BY-105 & 0.602 & 0.865 \\
\hline 241-BY-106 & 0.311 & 0.811 \\
\hline 241-BY-107 & 0.329 & 0.855 \\
\hline 241-BY-108 & 0.540 & 0.878 \\
\hline 241-BY-109 & 0.433 & 0.861 \\
\hline 241-BY-110 & 0.347 & 0.958 \\
\hline 241-BY-111 & 0.594 & 0.941 \\
\hline 241-BY-112 & 0.558 & 0.934 \\
\hline 241-C-101 & 0.517 & 1 \\
\hline 241-C-102 & 0.112 & 1 \\
\hline 241-C-103 & 0.487 & 0.627 \\
\hline 241-C-104 & 0.178 & 1 \\
\hline 241-C-105 & 0.537 & 1 \\
\hline 241-C-106 & 0.240 & 0.167 \\
\hline 241-C-107 & 0.218 & 1 \\
\hline 241-C-108 & 0.301 & 1 \\
\hline 241-C-109 & 0.361 & 1 \\
\hline 241-C-110 & 0.271 & 0.994 \\
\hline 241-C-111 & 0.363 & 1 \\
\hline 241-C-112 & 0.177 & 1 \\
\hline 241-C-201 & 0.562 & 1 \\
\hline 241-C-202 & 0.429 & 1 \\
\hline 241-C-203 & 0.383 & 1 \\
\hline 241-C-204 & 0.139 & 1 \\
\hline 241-S-101 & 0.239 & 0.823 \\
\hline 241-S-102 & 0.412 & 0.761 \\
\hline 241-S-103 & 0.363 & 0.760 \\
\hline 241-S-104 & 0.366 & 0.872 \\
\hline 241-S-105 & 0.417 & 0.898 \\
\hline
\end{tabular}

D.3 
Table D.1. (contd.)

\begin{tabular}{||l|c|c||}
\hline Tank & $\begin{array}{c}\text { Solid } \\
\text { volume } \\
\text { fraction in } \\
\text { wet bulk } \\
\text { solids }\end{array}$ & $\begin{array}{c}\text { Volume } \\
\text { fraction of } \\
\text { wet bulk } \\
\text { solids in } \\
\text { total waste }\end{array}$ \\
\hline \hline $241-\mathrm{S}-106$ & 0.450 & 0.943 \\
\hline $241-\mathrm{S}-107$ & 0.141 & 0.947 \\
\hline $241-\mathrm{S}-108$ & 0.394 & 0.993 \\
\hline $241-\mathrm{S}-109$ & 0.508 & 0.969 \\
\hline $241-\mathrm{S}-110$ & 0.582 & 0.922 \\
\hline $241-\mathrm{S}-111$ & 0.422 & 0.722 \\
\hline $241-\mathrm{S}-112$ & 0.634 & 0.873 \\
\hline $241-\mathrm{SX}-101$ & 0.350 & 0.861 \\
\hline $241-\mathrm{SX}-102$ & 0.162 & 0.777 \\
\hline $241-\mathrm{SX}-103$ & 0.306 & 0.899 \\
\hline $241-\mathrm{SX}-104$ & 0.342 & 0.940 \\
\hline $241-\mathrm{SX}-105$ & 0.191 & 0.886 \\
\hline $241-\mathrm{SX}-106$ & 0.245 & 0.901 \\
\hline $241-\mathrm{SX}-107$ & 0.275 & 0.958 \\
\hline $241-\mathrm{SX}-108$ & 0.367 & 1 \\
\hline $241-\mathrm{SX}-109$ & 0.387 & 1 \\
\hline $241-\mathrm{SX}-110$ & 0.317 & 1 \\
\hline $241-\mathrm{SX}-111$ & 0.254 & 0.915 \\
\hline $241-\mathrm{SX}-112$ & 0.310 & 0.936 \\
\hline $241-\mathrm{SX}-113$ & 0.244 & 1 \\
\hline $241-\mathrm{SX}-114$ & 0.298 & 0.816 \\
\hline $241-\mathrm{SX}-115$ & 0.185 & 1 \\
\hline $241-\mathrm{SY}-101$ & 0.222 & 0.273 \\
\hline $241-\mathrm{SY}-102$ & 0.368 & 0.096 \\
\hline $241-\mathrm{SY}-103$ & 0.240 & 0.440 \\
\hline $241-\mathrm{T}-101$ & 0.269 & 0.843 \\
\hline $241-\mathrm{T}-102$ & 0.645 & 0.595 \\
\hline $241-\mathrm{T}-103$ & 0.268 & 0.853 \\
\hline $241-\mathrm{T}-104$ & 0.217 & 1 \\
\hline $241-\mathrm{T}-105$ & 0.117 & 1 \\
\hline $241-\mathrm{T}-106$ & 0.484 & 1 \\
\hline $241-\mathrm{T}-107$ & 0.240 & 1 \\
\hline $241-\mathrm{T}-108$ & & \\
\hline
\end{tabular}


Table D.1. (contd.)

\begin{tabular}{||l|c|c||}
\hline Tank & $\begin{array}{c}\text { Solid } \\
\text { volume } \\
\text { fraction in } \\
\text { wet bulk } \\
\text { solids }\end{array}$ & $\begin{array}{c}\text { Volume } \\
\text { fraction of } \\
\text { wet bulk } \\
\text { solids in } \\
\text { total waste }\end{array}$ \\
\hline \hline $241-\mathrm{T}-109$ & 0.751 & 0.749 \\
\hline $241-\mathrm{T}-110$ & 0.026 & 0.998 \\
\hline $241-\mathrm{T}-111$ & 0.037 & 1 \\
\hline $241-\mathrm{T}-112$ & 0.052 & 0.897 \\
\hline $241-\mathrm{T}-201$ & 0.047 & 0.932 \\
\hline $241-\mathrm{T}-202$ & 0.022 & 1 \\
\hline $241-\mathrm{T}-203$ & 0.021 & 1 \\
\hline $241-\mathrm{T}-204$ & 0.027 & 1 \\
\hline $241-\mathrm{TX}-101$ & 0.372 & 0.953 \\
\hline $241-\mathrm{TX}-102$ & 0.418 & 0.853 \\
\hline $241-\mathrm{TX}-103$ & 0.450 & 0.874 \\
\hline $241-\mathrm{TX}-104$ & 0.474 & 0.847 \\
\hline $241-\mathrm{TX}-105$ & 0.470 & 0.951 \\
\hline $241-\mathrm{TX}-106$ & 0.423 & 0.885 \\
\hline $241-\mathrm{TX}-107$ & 0.625 & 0.750 \\
\hline $241-\mathrm{TX}-108$ & 0.437 & 0.928 \\
\hline $241-\mathrm{TX}-109$ & 0.326 & 1 \\
\hline $241-\mathrm{TX}-110$ & 0.396 & 0.981 \\
\hline $241-\mathrm{TX}-111$ & 0.388 & 0.991 \\
\hline $241-\mathrm{TX}-112$ & 0.448 & 0.955 \\
\hline $241-\mathrm{TX}-113$ & 0.543 & 0.991 \\
\hline $241-\mathrm{TX}-114$ & 0.450 & 0.963 \\
\hline $241-\mathrm{TX}-115$ & 0.434 & 0.951 \\
\hline $241-\mathrm{TX}-116$ & 0.505 & 0.953 \\
\hline $241-\mathrm{TX}-117$ & 0.488 & 0.984 \\
\hline $241-\mathrm{TX}-118$ & 0.742 & 0.856 \\
\hline $241-\mathrm{TY}-101$ & 0.366 & 0.996 \\
\hline $241-\mathrm{TY}-102$ & 0.568 & 0.739 \\
\hline $241-\mathrm{TY}-103$ & 0.228 & 0.935 \\
\hline $241-\mathrm{TY}-104$ & 0.281 & 0.976 \\
\hline $241-\mathrm{TY}-105$ & 0.448 & 1 \\
\hline $241-\mathrm{TY}-106$ & 0.479 & 1 \\
\hline $241-\mathrm{U}-101$ & 0.318 & 1 \\
\hline
\end{tabular}

D.5 
Table D.1. (contd.)

\begin{tabular}{||l|c|c||}
\hline Tank & $\begin{array}{c}\text { Solid } \\
\text { volume } \\
\text { fraction in } \\
\text { wet bulk } \\
\text { solids }\end{array}$ & $\begin{array}{c}\text { Volume } \\
\text { fraction of } \\
\text { wet bulk } \\
\text { solids in } \\
\text { total waste }\end{array}$ \\
\hline \hline $241-U-102$ & 0.248 & 0.955 \\
\hline $241-U-103$ & 0.292 & 0.914 \\
\hline $241-U-104$ & 0.129 & 1 \\
\hline $241-U-105$ & 0.494 & 0.875 \\
\hline $241-U-106$ & 0.132 & 0.742 \\
\hline $241-U-107$ & 0.560 & 0.714 \\
\hline $241-U-108$ & 0.392 & 0.726 \\
\hline $241-U-109$ & 0.433 & 0.905 \\
\hline $241-U-110$ & 0.245 & 1 \\
\hline $241-U-111$ & 0.319 & 0.769 \\
\hline $241-U-112$ & 0.449 & 1 \\
\hline $241-U-201$ & 0.232 & 0.789 \\
\hline $241-U-202$ & 0.226 & 0.765 \\
\hline $241-U-203$ & 0.175 & 0.765 \\
\hline $241-U-204$ & 0.452 & 0.733 \\
\hline$*$ & $\begin{array}{l}\text { According to the BBI there is no solid in these } \\
\text { tanks. } \\
\text { Owing to approximations, the dry solid volume } \\
\text { fraction was calculated to be greater than 1, a } \\
\text { physically unrealistic value. A value of } 1 \text { was } \\
\text { substituted in the SOF calculations for wet bulk } \\
\text { solids. }\end{array}$ & \\
\hline \hline
\end{tabular}




\section{Distribution}

No. of

$\underline{\text { Copies }}$

\section{ONSITE}

9 CH2M Hill Hanford Group

$\begin{array}{lr}\text { SJ Eberlein } & \text { R2-58 } \\ \text { T Goetz } & \text { R2-12 } \\ \text { JM Grigsby } & \text { S7-90 } \\ \text { SD Kozlowski } & \text { R2-12 } \\ \text { LJ Kripps } & \text { S7-90 } \\ \text { JE Meacham (3) } & \text { R2-58 } \\ \text { Correspondence Control } & \text { H6-08 }\end{array}$

6 Pacific Northwest National Laboratory

JL Huckaby K7-15

LA Mahoney (3) K7-15

Information Release (2) P8-55

Distr. 1 